ANA PAULA SILVA DE AZEVEDO DOS SANTOS

EFEITO DO MICROAMBIENTE TUMORAL SOBRE AS

CARACTERÍSTICAS FUNCIONAIS E FENOTÍPICAS DE

CÉLULAS DENDRÍTICAS GERADAS IN VITRO A PARTIR

DE MONÓCITOS DO SANGUE PERIFÉRICO DE VOLUNTÁRIAS

SAUDÁVEIS E DE PACIENTES COM CÂNCER DE MAMA

Tese apresentada ao Programa de PósGraduação em Imunologia do Instituto de Ciências Biomédicas da Universidade de São Paulo para obtenção do Título de Doutor em Ciências 
ANA PAULA SILVA DE AZEVEDO DOS SANTOS

EFEITO DO MICROAMBIENTE TUMORAL SOBRE AS

CARACTERÍSTICAS FUNCIONAIS E FENOTÍPICAS DE

CÉLULAS DENDRÍTICAS GERADAS IN VITRO A PARTIR

DE MONÓCITOS DO SANGUE PERIFÉRICO DE VOLUNTÁRIAS

SAUDÁVEIS E DE PACIENTES COM CÂNCER DE MAMA

Tese apresentada ao Programa de PósGraduação em Imunologia do Instituto de Ciências Biomédicas da Universidade de São Paulo para obtenção do Título de Doutor em Ciências

Área de concentração: Imunologia

Orientador: Prof. Dr. José Alexandre M. Barbuto 
FOLHA DE APROVAÇÃO 


\section{PARECER 695/CEP}

Prezada Senhora,

Atendendo sua solicitação, a Comissão de Ética em Pesquisas com Seres Humanos do ICB, em sua qüinquagésima nona reunião, analisou o projeto de sua responsabilidade intitulado: “Efeito do microambiente tumoral sobre as caracteristicas funcionais e fenotipicas de células dendriticas geradas in vitro a partir de monócitos do sangue periférico de voluntárias saudáveis e de pacientes com câncer de mama”.

Informo a V.Sa. que, após análise e discussão, o referido projeto foi aprovado por esta Comissão.

Esclareço a V.Sa. que dentro de 12 meses, relatório do referido projeto deverá ser encaminhado à Secretaria deste CEP.

Atenciosamente,

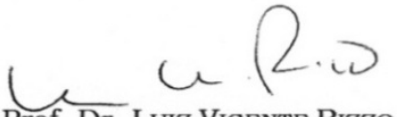

Prof. Dr. LuIz Vicente Rizzo

Coordenador da Comissão de Ética em

Pesquisas com Seres Humanos - ICB/USP

Ilma. Sra.

ana Paula Silva de Azevedo dos Santos

Departamento de Imunologia

Instituto de Ciências Biomédicas -USP

Comissão de Ética em Pesquisa com Seres Humanos do Instituto de Ciências Biomédicas / USP

Aprovada pela Comissão Nacional de Ética em Pesquisa - CONEP, em 10 de fevereiro de 1998. 
SECRETARIA DE ESTADO DA SAÚDE

Centro de Referência da Saúde da Mulher

Comitê de Ética em Pesquisa

São Paulo, 29 de junho de 2006

FORMULÁRIO DE APROVAÇÃO DO COMITÊ DE ÉTICA EM PESQUISA

DATA DA APROVAÇÃO :28/06/06

TÍTULO DO ESTUDO: "Efeito microambiente tumoral sobre as características funcionais e Fenotípicas de Células Dentricas geradas IN VITRO a partir de Monócitos do Sangue Periférico de Voluntários Saudáveis e de Pacientes com Câncer de Mama".

NOME DO INVESTIGADOR PRINCIPAI: Dra Ana Paula S. de Azevedo Santos APROVAÇÃO DO COMITÊ DE ÉTICA

O Comitê de Ética em Pesquisa do Centro de Referência da Saúde da Mulher APROVOU o Protocolo de Pesquisa e Termo de Consentimento Livre e Esclarecido ,tendo sido a referida aprovação constado em ata.

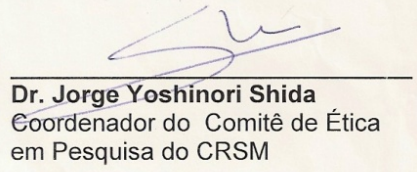


Ao meu marido Ricardo, aos meus pais Paulo e Marileide, irmãos Paulo e Patrícia e meus sobrinhos pela dedicação e incentivo e a tia Glória (in memoriam) pelo exemplo de perseverança. 


\section{AGRADECIMENTOS}

Ao meu marido que compartilhou com paciência e companheirismo todos os momentos.

Aos meus pais pelo carinho e incentivo constante a minha educação, e meus irmãos pelo apoio.

Ao meu orientador Prof. Dr. José Alexandre M. Barbuto pela oportunidade de vivenciar a ciência com humanidade e sabedoria.

A Dra. Patricia Bergami pelas conversas agradáveis e construtivas.

Ao Dr. Fábio Laginha que me acompanhou na coleta das amostras, ajudou na compreensão dos dados clínicos e participou da banca de qualificação.

A Dra. Profa. Maria Aparecida Nagai por ter me recebido no seu laboratório, onde tive a oportunidade de aprender mais, e por ter me dado sugestões durante a qualificação que foram essenciais para a realização deste trabalho.

A Profa. Dra. Maristela Camargo pelas opiniões e por ter cedido o inibidor de sinalização celular usado neste trabalho.

Ao Prof. Dr. Niels pelas sugestões valiosas dadas na qualificação.

A Equipe de Mastologia do Hospital Pérola Byington representada pela Dra. Marianne Pinotti pela cordialidade e colaboração na realização do trabalho.

Ao setor de Patologia do Hospital Pérola Byington, representada pela Dra. Marlene B. Santos, Dr. Victor Arias, Rosemeire Martins e Eliana Vieira pela atenção e amabilidade com a qual me receberam e pela ajuda no processamento das amostras de tumor.

Aos professores Momtchilo Russo, Sônia Jancar Negro, Vera Calich, Lourdes Isaac, Ises Abrahamsohn, Regina D’Império Lima, Karina Bortoluci, Eliana Mauro, Maristela Camargo, Gustavo Amarante-Mendes, José M. Álvarez Mosig, Luiz Vicente Rizzo pelas aulas ministadas.

Aos amigos de laboratório de Imunologia de Tumores Ana Carolina, Andréia, Bruna, Bruno, Clara, Cristiano, Daniel, Gabriela, Giovana, Giovana Cechim, Graziela, 
Isabella, João Paulo, Karem, Lilian, Márcio, Marisa, Murilo, Otávio, Patrícia, Renato, Roberta, Roberto e Rodrigo pelos momentos maravilhosos dentro e fora do laboratório.

A Célia pelos ensinamentos na cultura de célula e pela atenção constante.

A Tânia e Rogério pela disponibilidade quando precisava irradiar as células para cultura.

Aos amigos do Instituto de Radiologia, Michelly, Simone, Sibele, Flávia, Daniel, Natan, Érika e D. Antônia pela ajuda nos experimentos e pela amizade.

A minha amiga Andrea pela companhia, pela atenção e ajuda permanente, mesmo quando eu estava longe.

Ao Prof. Dr. Magnus Gidlund, Silvana, Gabriela, Eduardo sempre tão receptivos e atenciosos.

Aos meus amigos Flávia, Lucilene, Socorro, Lilaléia, Paulinha, Paulo Victor, Josias e Walmir que sempre me apoiaram e me ajudaram na jornada dupla de estudo e trabalho.

Aos amigos Jotelma, Amanda, Eny, Celso e Amarildo (in memoriam) pela ajuda nas questões burocráticas.

Aos amigos da portaria Milton, Octacílio, Roberto, Odair e Ailton.

A FAPESP e FAPEMA pelo apoio financeiro.

E a todas as pessoas que ajudaram na realização deste trabalho de forma direta ou indireta.

Obrigada a todos! 
"Concedei-nos Senhor, Serenidade necessária, para aceitar as coisas que não podemos modificar, Coragem para modificar aquelas que podemos e Sabedoria para distinguirmos umas das outras."

(Reihold Niebuhr) 


\section{RESUMO}

Azevedo-Santos APS. Efeito do microambiente tumoral sobre as características funcionais e fenotípicas de células dendríticas geradas in vitro a partir de monócitos do sangue periférico de voluntárias saudáveis e de pacientes com câncer de mama. [tese (Doutorado em Imunologia)]. São Paulo (Brasil): Instituto de Ciencias Biomédicas, Universidade de São Paulo; 2010

Células dendríticas (DCs) são as principais células apresentadoras de antígenos e as únicas capazes de dar início a uma resposta imune primária. As DCs são alvo de inúmeros processos capazes de afetar sua função em pacientes com câncer. No câncer de mama, o metabolismo anaeróbico, ação local dos estrógenos e o uso terapêutico de seus antagonistas são fatores comuns à boa parte das pacientes, que podem influenciar as DCs. Assim, o presente trabalho avaliou o perfil fenotípico de DCs em amostras tumorais das pacientes, a diferenciação de DCs a partir de células mononucleares derivadas do sangue periférico (PBMCs) das pacientes, comparouse suas características fenotípicas e funcionais, investigou-se os efeitos de moduladores de estrógenos (tamoxifeno), da co-cultura com linhagens tumorais e de inibidores da p38 MAPK sobre as DCs, tanto de indivíduos sadios quanto de pacientes com câncer de mama ductal invasivo. Os resultados mostraram que há diferença na capacidade de geração, no fenótipo e na capacidade aloestimuladora das DCs derivadas de PBMCs de pacientes. As DCs de pacientes apresentaram maior produção de interleucina 10 e expressaram mais HSP27, enquanto que as DCs de voluntárias saudáveis apresentaram maior produção de Interferon-gama. A via p38 MAPK parece ser importante na diferenciação de monócitos em DCs, entretanto, estímulos estressantes podem ativar esta via e induzir a síntese de HSP27 inibindo este processo. O tratamento com tamoxifeno parece modular a expressão de algumas moléculas de membrana durante a diferenciação das DCs. Desta forma, os resultados sugerem que as DCs diferenciadas de PBMCs de pacientes com câncer de mama apresentam alterações fenotípicas e funcionais que são pelo microambiente tumoral.

Palavras-chave: Células Dendríticas. Cancer de mama. Microambiente tumoral. 


\begin{abstract}
Azevedo-Santos APS. Effect of the tumor microenvironment on the function and phenotype of dendritic cells generated in vitro from monocytes obtained from healthy volunteers and breast cancer patients. [Ph. D. thesis (Immunology)]. São Paulo (Brazil): Instituto de Ciências Biomédicas da Universidade de São Paulo; 2010.

Dendritic cells (DCs) are a recognized as the most potent antigen-presenting cells and are uniquely able to initiate primary immune responses. Not surprisingly, they are targets of tumors evasion mechanisms, affecting their function in cancer patients. In breast cancer, the anaerobic metabolism, the action of estrogens antagonists are common factors to most patients, which can influence DC generation. Thus the aim of this work was to evaluate the frequency of DCs in tumor tissue. In addition, we evaluated the differentiation of DCs derived from peripheral blood mononuclear cells (PBMCs) and compared the phenotypic and functional characteristic of these cells, the effects of selective estrogen receptor modulators (tamoxifen), the co-culture with tumor cell and the specific p38 MAPK inhibitor on DCs from healthy individuals and breast cancer patients. The results showed that patients' PBMCs were unable to generate phenotypicaly and functionally mature DCs when compared with healthy volunteers' DCs. DCs differentiated of patients' PBMCs presented larger production of interleukin 10 and higher expression of HSP27, while DCs derived from healthy volunteers' PBMCs presented higher production of Interferon-gamma. The p38 MAPK signaling pathway seems to be important in monocyte differentiation into DCs, and its activation by stress can induce the synthesis of HSP27, a protein that inhibits DC generation. The treatment with tamoxifen caused modulation of membrane DC markers' expression. Therefore, these results show that DCs derived from patients' PBMCs present phenotypic and functional alterations which can be caused by tumor microenvironment factors.
\end{abstract}

Key words: Dendritic cell. Breast cancer. Tumoral microenvironment. 


\section{LISTA DE ILUSTRAÇÕES}

Figura 1- Efeito de acidificação do meio na diferencia ção das DCs

Figura 2- Gráficos representativos das células obtidas na cultura de diferenciação de células PBMCs em DCs

Figura 3- Análise fenotípica de marcadores celulares para caracterização de DCs em suspensão de células obtidas do tecido tumoral digerido com colagenase

Figura 4- Imunohistoquímica da frequência de marcadores celulares de DCs e macrófafos presentes no tecido tumoral

Figura 5- Gráficos representativos das populações de células por tamanho (FSC) e granulosidade (SSC) antes e depois da cultura de diferenciação em DCs

Figura 6- Freqüência de células expressando os marcadores celulares CD14, CD80, CD86, CD11c e HLA-DR, antes e depois da cultura de diferenciação suplementada com IL-4, GM-CSF e $\mathrm{TNF} \alpha$

Figura 7- Rendimento relativo de cultura para diferenciação em DCs em voluntárias saudáveis e portadoras de câncer de mama

Figura 8- Comparação fenotípica entre DCs obtidas a partir de PBMCs de voluntárias saudáveis e de pacientes com câncer de mama.. 60

Figura 9- DCs diferenciadas de PBMCs de pacientes apresentam menor capacidade de induzir linfoproliferação que DCs diferenciadas a 
partir de PBMCs de voluntárias saudáveis

Figura 10- Concentração de IFN- $\gamma$ e IL-10 no sobrenadante da co-cultura de linfócitos alogenéicos com DCs obtidas de PBMCs de voluntárias e de pacientes

Figura 11- Expressão dos receptores para citocinas GM-CSF (CD116) e IL4 (CD124) em PBMCs CD14 em voluntárias e de pacientes..

Figura 12- Efeito da co-cultura de DCs com linhagens tumorais de MCF-7 e SK-BR-3 sobre o fenótipo

Figura 13- Efeito da co-cultura de DCs com linhagens tumorais de MCF-7 e SK-BR-3 sobre a capacidade de induzir linfoproliferação e na dosagem de citocinas

Figura14- Efeito de fatores solúveis na co-cultura de DCs com linhagens tumorais de MCF-7 e SK-BR-3 sobre a capacidade de induzir linfoproliferação e na dosagem de citocinas

Figura 15- Efeito do ácido lático no fenótipo de DCs derivadas de PBMCs de voluntárias e de pacientes com cancer mamário

Figura 16- Efeito do ácido lático na função de DCs derivadas de PBMCs de voluntárias e de pacientes com câncer mamário

Figura 17- Efeito da p38MAPK no fenótipo e na função de DCs derivadas de PBMCs de voluntárias e de pacientes com cancer de mama diferenciadas em $\mathrm{pH}$ normal e $\mathrm{pH}$ ácido

Figura 18- Efeito da p38MAPK na produção de citocinas no sobrenadante de MRL de DCs derivadas de PBMCs de voluntárias e de pacientes com cancer de mama mantidas em $\mathrm{pH}$ normal ou $\mathrm{pH}$ ácido 
Figura 19- Efeito do inibidor p38MAPK e do ácido lático na expressão do RNAm para HSP27 em DCs derivadas de PBMCs obtidas de voluntárias e de pacientes com cancer de mama

Figura 20- Expressão do RNAm para HSP27 em DCs derivadas de PBMCs obtidas de voluntárias e de pacientes com cancer de mama mantidas em co-cultura com linhagens tumorais de mama

Figura 21- Comparação entre a cultura de DCs derivadas de PBMCs obtidas de voluntárias e de pacientes que sofreram mastectomia e em tratamento com tamoxifeno

Figura 22- Comparação fenotípica entre a cultura de DCs derivadas de PBMCs obtidas de voluntárias e de pacientes ambulatoriais

Figura 23- Comparação funcional entre a cultura de DCs derivadas de PBMCs obtidas de voluntárias e de pacientes ambulatoriais .....

Figura 24- Comparação fenotípica de DCs derivadas de PBMCs obtidas de voluntárias e de pacientes com cancer de mama tratadas com Tamoxifeno

Figura 25- Comparação funional de DCs derivadas de PBMCs obtidas de voluntárias e de pacientes com cancer de mama tratadas com Tamoxifeno

Figura 26- Esquema hipotético das interações dos fatores do microambiente tumoral sobre a diferenciação das DCs a partir de PBMCs de voluntárias saudáveis e pacientes com câncer de mama 


\section{LISTA DE TABELAS}

TABELA 1- Dados clínicos e anatomopatológicos das pacientes com carcinoma ductal mamário..

TABELA 2- Dados clínicos e anatomopatológicos das pacientes atendidas no ambulatório 


\section{LISTA DE ABREVIATURAS E SIGLAS}

17 $\beta$ HSD $\quad 17 \beta$ Hidroxiesteroide deidrogenase

AET 2-aminoethylisothiouronium bromide hydrobromide

APCs Células Apresentadoras de Antígenos

CD Cluster of diferentiation

CCR7 Receptor de quimiocina 7

CFSE Carboxyfluorescein Succinimidyl Ester

CTLS Células T citotóxicas

DCs Células Dendríticas

DMSO Dimetilsulfóxido

E1 Estrona

E2 Estradiol

E3 Estriol

EDTA Etilenodiaminotetracético

G-CSF Fator de Crescimento de Colônia de Granulócito

GM-CSF Fator de Crescimento de Colônia de Granulócito e Macrófago

HGF Fator de Crescimento do Hepatócito

HLA-ABC Antígeno Leucocitário Humano-ABC

HLA-DR Antígeno Leucocitário Humano-DR

HSP Proteína de Choque Térmico

IL Interleucina

JAK Quinase de janus

kDa Kilodaltons

MAPK Proteína quinase Ativada pelo Mitógeno

MCF7 Linhagem de células de adenocarcinoma de mama humano (Michigan Cancer Foundation - 7)

MFI Média de Intensidade de Fluorescência

MHC-cl I Complexo Principal de Histocompatibilidade classe I

MHC-cl II Complexo Principal de Histocompatibilidade classe II

MRL Ensaio de estimulação de linfócitos $T$ alogenéicos

NFKB $\quad$ Fator Nuclear $\mathrm{kB}$ 


$\begin{array}{ll}\text { PBMCs } & \text { Células Mononucleares do Sangue Periférico } \\ \text { PCR } & \text { Reação em Cadeia da Polimerase } \\ \text { MAPK } & \text { Proteína quinase Ativada por Mitógeno } \\ \text { S100 } & \text { Proteína de baixo peso molecular usado como marcador para } \\ & \text { Células Dendríticas } \\ \text { SFB } & \text { Soro Fetal Bovino } \\ \text { SK-BR-3 } & \text { Linhagem celular de adenocarcinoma de mama } \\ \text { STATs } & \text { Transdutores de sinal e ativadores de transcrição } \\ \text { Sch } & \text { do inglês Src homology collagen } \\ \text { Th1 } & \text { Células T "helper" 1 } \\ \text { Th2 } & \text { Células T "helper" 2 } \\ \text { TGF } \beta & \text { Fator de Crescimento e Transformação } \beta \\ \text { TNF } \alpha & \text { Fator de Necrose Tumoral } \alpha \\ \text { VIP } & \text { Peptídio Intestinal Vasoativo }\end{array}$




\section{SUMÁRIO}

1 INTRODUÇÃO E JUSTIFICATIVA …............................................ 21

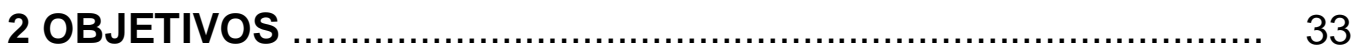

2.1 Objetivo Geral .................................................................... 33

2.2 Objetivos Específicos …………........................................ 33

3 MATERIAL E MÉTODOS …................................................ 35

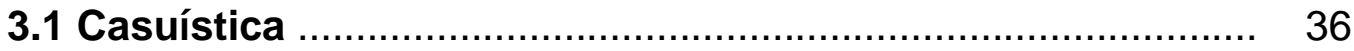

3.2 Coleta do tumor ……........................................................ 38

3.3 Imunohistoquimica ……............................................ 38

3.4 Processamento do tumor com colagenase .......................... 40

3.5 Obtenção das amostras de sangue periférico ...................... 41

3.6 Isolamento de monócitos e diferenciação em DCs ................ 41

3.7 Estudo fenotípico por citometria de fluxo ............................. 44

3.8 Identificação do "gate" para análise das DCs ....................... 45

3.9 Separação de Linfócitos T ................................................ 46

3.10 Avaliação da atividade aloestimuladora das DCs …............ 47

3.11 Detecção de citocinas por ensaio imunoenzimático

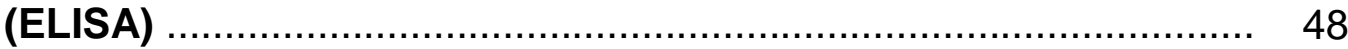

3.12 Extração de RNA e síntese do cDNA .................................. 49

3.13 PCR quantitativa em tempo real (qPCR) ……..................... 50

3.14 Análise estatística .................................................... 51

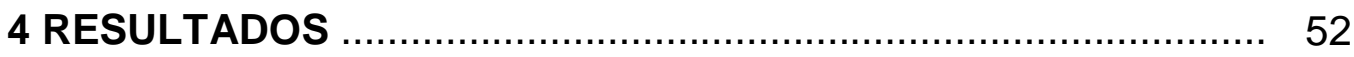

4.1 Análise das DCs infiltradas no tumor .................................. 53

4.2 Imunohistoquímica de marcadores de células imunes 
presentes nos carcinomas mamários

4.3 Comparação morfológica e fenotípica das células obtidas de voluntárias e de pacientes com câncer de mama antes e depois da cultura de diferenciação de PBMCs em DCs

4.4 Comparação do rendimento da cultura de DCs a partir de PBMCs de voluntárias saudáveis e de pacientes com câncer de mama

4.5 Comparação fenotípica e funcional das DCs diferenciadas de PBMCs de voluntárias e de pacientes com câncer de mama.. 59

4.6 Expressão de receptores para IL-4 e GM-CSF em monócitos obtidos do sangue periférico de voluntárias saudáveis e de pacientes com cancer de mama

4.7 Efeito da presença das células tumorais ou seus fatores solúveis na ativação de DCs a partir de PBMCs obtidas de voluntárias saudáveis e pacientes com câncer de mama

4.8 Efeito do $\mathrm{pH}$ baixo induzido pelo ácido láctico na diferenciação de DCs a partir de PBMCs de voluntárias e de pacientes

4.9 Participação da via p38MAPK nas alterações fenotípicas e funcionais induzidas pelo ácido lático na cultura de diferenciação de PBMCs de voluntárias e de pacientes em DCs

4.10 Expressão de HSP27 em DCs diferenciadas de PBMCs de voluntárias e de pacientes 
4.11 Avaliação fenotípica e funcional das DCs obtidas de PBMC de pacientes em tratamento com Tamoxifeno após mastectomia

4.12 Efeito do Tamoxifeno no fenótipo e na função das DCs diferenciadas de PBMCs de voluntárias saudáveis e de pacientes com mama

5 DISCUSSÃO 85

6 CONCLUSÃO 99

REFERÊNCIAS 102 
1 INTRODUÇÃO E JUSTIFICATIVA 
Nos últimos anos a Imunologia vem se consolidando, cada vez mais, como uma ciência complexa e intrigante. Deixando de ser vista apenas como um sistema de defesa contra microorganismos, o sistema imune pode ser explicado como um sistema celular e molecular organizado que apresenta um funcionamento complexo e diversificado, conferindo um equilíbrio interno responsável pela manutenção da integridade orgânica.

Com um maior conhecimento sobre os elementos que formam a imunidade e como eles atuam na preservação do próprio, a imunologia vem sendo aplicada, de forma crescente, nos estudos relacionados à carcinogenese. O câncer é uma doença genética, em que a célula tumoral, apesar de se originar da célula normal, se diferencia desta por apresentar mecanismos ineficientes de controle de proliferação celular, instabilidade gênica e cromossômica, desregulação nos mecanismos de apoptose, além de adquirir a capacidade de invasão e crescimento em locais distantes de sua origem (Bast, 2003). Assim, a Imunologia dos Tumores compreende os fenômenos relacionados às possíveis interações entre os diversos componentes do sistema imune e do tumor.

As alterações gênicas ocorridas nas células tumorais poderiam gerar diversos antígenos, teoricamente capazes de desencadear respostas imunes nos indivíduos onde elas ocorrem (revisto por Barbuto, 2004). Se isto é fato, seria de se esperar um papel significativo do sistema imune na biologia dos tumores. Esta proposição é a da teoria da vigilância imunológica, que, no entanto, não foi ainda definitivamente provada nem refutada.

Por outro lado, é importante notar que tumores estabelecidos apresentam inúmeros mecanismos de escape frente à resposta imune (Klein, 1976). Tal fenômeno indica a existência de uma pressão seletiva exercida pelo sistema imune 
sobre as células tumorais, fazendo que apenas sobrevivam células capazes de burlar, de uma ou outra maneira a resposta imune dirigida contra elas (Lattime e Stutman, 1989).

Uma maneira de dificultar o reconhecimento antigênico das células neoplásicas pode ser observada, por exemplo, em células do tumor de mama, que apresentam modificações nos antígenos de superfície e na estrutura do glicocálix (Kim et al., 1975) além de liberarem enzimas, como colagenase, proteases, glicosidases e metaloproteinases, modificando a superfície e o meio próximo à célula tumoral (Bast, 2003).

O tumor pode, ainda, utilizar-se da resposta imune a seu favor, pois o processo inflamatório ativa células que podem criar um ambiente favorável a promoção de células pré-neoplásicas, além de liberar fatores de crescimento, induzir a angiogênese e remodelar da matriz extracelular propiciando o aparecimento de metástases (Coussens e Werb, 2002). Macrófagos associados ao tumor, embora possam matar as células tumorais quanto ativados por interferons ou interleucinas (IL)- 2 e 12, também produzem fatores de crecimento, angiogênicos, linfogênicos, citocinas e proteases que potencializam a progressão do tumor, bem como podem produzir IL-10 que impede a resposta antitumoral mediada por células T (Brigati et al., 2002; Tsung et al., 2002; Schoppmann et al., 2002; Torisu et al., 2000). Em modelos murinos de carcinoma hepatocelular originado de hepatite colestática, foi observado que o fator nuclear $\kappa \mathrm{B}(\mathrm{NF}-\mathrm{\kappa} \mathrm{B})$, um importante fator celular que participa da inflamação, apresenta-se ativado nos hepatócitos em decorrência do processo inflamatório via liberação parácrina de Fator de Necrose Tumoral $\alpha$ (TNF- $\alpha$ ), causando efeitos anti-apoptóticos que podem estar relacionados aos mecanismos de progressão de tumores associados à inflamação crônica (Pikarsky et al., 2004). 
Outro mecanismo descrito é a produção, no micro-ambiente tumoral, de citocinas como o Fator de Crescimento e Transformação (TGF) beta (Tada et al., 1991) ou IL-10, IL-4 e IL-5 (Yamamura et al., 1993), todas com atividade imunossupressora conhecida. Na verdade, o micro-ambiente tumoral apresenta uma série de outras características muito interessantes e capazes de afetar funcionalmente as células ali presentes. Uma destas características, extremamente frequente, e por isso explorada clinicamente para o diagnóstico por imagem da presença de lesões metastáticas, é a alta taxa de metabolismo anaeróbico de glicose, mesmo em condições de boa oxigenação do tumor (Semenza, 2001). Esta característica gera um micro-ambiente ácido e rico em lactato, que pode contribuir para a seleção de células tumorais mais invasivas e, portanto, capazes de promover o desenvolvimento de metástases (Gatenby e Gillies, 2004). Entretanto, este efeito selecionador sobre as células tumorais pode não ser a única conseqüência deste fenômeno, outros tipos celulares ali presentes podem ser afetados pelo mesmo.

De qualquer forma, embora não se possa delinear, com precisão, o papel da resposta imune em cada neoplasia, pode-se considerar que as interações entre sistema imune e tumores constituem um fator significativo na história natural destas doenças (Sellin, 1979). Assim, atualmente, a "imunoedição" define todas estas alterações induzidas pelo sistema imune e que participam da patogênese dos tumores (Dunn et al., 2002; Dunn et al., 2004; Reiman et al., 2007).

Dentre as várias células potencialmente presentes no micro-ambiente tumoral estão às células dendríticas (DCs). Estas se encontram amplamente distribuídas nos tecidos, principalmente na pele e nas mucosas, num estado "imaturo", em que apresentam uma grande capacidade endocítica e fagocítica, realizando uma amostragem contínua do micro-ambiente onde se encontram (revisto por 
Banchereau e Steinman, 1998; Banchereau et al., 2000; Mohamadzadeh e Luftig, 2004). Ao sofrerem determinados estímulos estas DCs imaturas sofrem um processo de maturação, apresentando, então, redução de sua capacidade endocítica e fagocítica, aumento na produção de citocinas inflamatórias e aquisição da capacidade de migração, principalmente através da expressão de receptores para quimiocinas, como o CCR7 (Caux et al., 1994; Yanagihara et al., 1998; Guermonprez et al., 2002). A expressão deste receptor permite que as DCs que captaram antígenos dirijam-se aos tecidos linfóides, mais especificamente para áreas de células $T$, onde são capazes de recrutar outras DCs e linfócitos, através da liberação de quimiocinas facilitando as interações celulares necessárias para o desenvolvimento de uma resposta específica eficiente (Adema et al., 1997; Sozzani et al., 1998; Sallusto et al., 1999; Kato et al., 2000). Além disso, a maturação das DCs também é caracterizada pelo aumento da expressão de moléculas de classe II codificadas pelo complexo principal de histocompatibilidade (MHC-cl II) e de moléculas co-estimuladoras (CD80, CD86 e CD40) em sua superfície, o que as torna capazes de ativar de forma efetiva linfócitos T em células efetoras ou de memória (Caux et al., 1994; Banchereau et al., 2000). Dependendo do tipo e do modo em que é ativada, as DCs são capazes de apresentar antígenos exógenos tumorais solúveis para linfócitos T "naive" tanto no contexto de moléculas de MHC-cl I quanto em moléculas de MHC-cl II (Nagata et al., 2002; Schnurr et al., 2005). Desta forma, frente aos tumores, as DCs parecem ter um papel essencial, uma vez que são capazes de processar e apresentar peptídeos tumorais para os linfócitos T citotóxicos (CTLs) via moléculas MHC-cl I, possibilitando assim, uma resposta antitumoral (Albert et al., 1998; Cutler et al., 2001). Novamente, também frente a 
tumores de mama há relato de função semelhante das DCs (Neidhardt-Berard et al., 2004).

Entretanto, tem sido demonstrado que as DCs têm um papel relevante não só na indução de respostas imunes, como descrito acima, mas também na indução da tolerância periférica, sendo esta complementar à tolerância central, na função de presenvação dos tecidos próprios. As DCs estão continuamente captando e processando antígenos, inclusive antígenos próprios, que, no contexto sem inflamação ou infecção, isto é, sem "sinais de perigo", são apresentados às células T nos tecidos linfoides secundários pelas DCs em um estado imaturo e indutor de tolerância. Desta forma, o estado de maturação das DCs é determinante para indução de imunogenicidade ou tolerância (Steinman et al., 2000; Steinman et al., 2003). Frente a um tumor, a apresentação de antígenos tumorais por DCs imaturas pode induzir a deleção ou anergia de células T tumor-específicas nos linfonodos, impedido o desenvolvimento de uma resposta antitumoral eficiente. (Steinman et al., 2003).

Considerando, assim, o papel fundamental das DCs no estabelecimento da resposta imune, o de únicas células apresentadoras de antígenos capazes de desencadear uma resposta imune primária (revisto por Banchereau e Steinman, 1998), é razoável esperar que estas células sejam, também, alvo dos mecanismos de escape tumoral. Confirmando esta hipótese, pode-se notar que DCs infiltradas em diversos tumores, (Ninomiya et al., 1999; Reichert et al., 2001; Dallal et al. 2002; Tourkova et al., 2004; Baleeiro et al., 2008) inclusive no de mama, apresentam alterações na expressão de marcadores de ativação, sendo seu número e estado funcional afetados dentro do micro-ambiente tumoral (Coventry et al., 2002; Coussens e Werb, 2002). 
As alterações fenotípicas e funcionais sofridas pelas DCs podem ser causadas por vários fatores, como por exemplo, as citocinas produzidas no microambiente tumoral, várias das quais têm efeito deletério sobre a função das DCs (Vassiliou et al., 2003; Kobie et al., 2003; Park et al., 2005), a produtos específicos de determinados tipos de câncer (McKallip et al., 1999; Makarenkova et al. 2003; Peguet-Navarro et al., 2003; Sharma et al., 2003; Monti et al., 2004) ou ainda, a características menos específicas de um ou outro tumor, mas comuns à maioria destes, como a acidez e o alto conteúdo de lactato do micro-ambiente (Gatenby e Gillies, 2004). Vários fatores de crescimento, incluindo IL10, TGF- $\beta$, Fator Estimulate de Colônia de Granulócitos (G-CSF), Fator de Crescimento de Hepatócitos (HGF) e Peptídio Intestinal Vasoativo (VIP) modulam a diferenciação das DCs favorecendo sua permanência num estado imaturo (Rutella et al., 2006). Recentemente, foi demonstrado que, o ácido láctico produzido por células de melanoma em cultura é capaz de modular o fenótipo das DCs, podendo, in vivo, teoricamente contribuir para o mecanismo de escape tumoral (Gottfried et al., 2006).

Assim, em condições estressantes como, variação de temperatura, estresse oxidativo ou exposição a drogas anticâncer, vias celulares de sobrevivência e de reorganização são ativadas, resultando na síntese de proteínas do tipo chaperonas chamadas de Proteínas de Choque Térmico (HSPs), principalmente a HSP27 e a HSP70 (Schmitt et al., 2007). Uma vez induzidas, as HSPs influenciam a agregação, o transporte e o dobramento de outras proteínas, como filamentos de actina do citoesqueleto, além de modular os mecanismos de apoptose resultando em estabilização celular frente ao dano causado pelo fator estressante (Schmitt et al., 2007; Kostengo e Moens, 2009). Há dados que indicam que o aumento de expressão desta chaperona se deve à ativação da via de sinalização da Proteína 
Quinase Ativada por Mitógenos (MAPK) p38, que conduz à fosforilação e à ativação de diferentes fatores necessários para a realização da resposta celular ao estresse (Waskiewicz e Cooper, 1995; Beyaert et al., 1996).

As MAPKs são proteínas associadas a receptores celulares e são ativadas em resposta a estresse químico ou físico, induzindo vias de sinalização que regulam várias funcões celulares como divisão, diferenciação, migração e apoptose (Chang, 2001). A p38MAPK é uma MAPK de 38kDa que apresenta no seu sítio de fosforilação um motivo conservado "TXY", onde T é a treonina, $X$ é a Glicina e $Y$ é a tirosina, podendo ser ativada por fatores estressantes e estímulos pró-inflamatórios (Freshney et al., 1994; Dong et al., 2002). Um piridinil imidazol, SB203580, pode ser usado como um inibidor específico para o estudo do papel fisiológico esta via de sinalização (Cuenda et al.,1995)

$\mathrm{Na}$ injúria nervosa, a HSP 25, um homólogo em camundongos da HSP27 humana, tem um papel central na regeneração e prevenção da morte do nervo, e sua indução também requer a via da p38MAPK (Murashov et al., 2001). Experimentos desenvolvidos em modelos animais têm demonstrado que a HSP27 e a HSP70 aumentam o potencial tumorigênico em células neoplásicas (Schmitt et al., 2007). Em monócitos foi descrito que a HSP27 bloqueia sua capacidade de diferenciação em DCs ou macrófagos e induz a síntese de IL-10 (De et al., 2000; Laudanski et al., 2007).

Assim, as DCs parecem ser um alvo relevante para os mecanismos de escape tumoral e, portanto, estratégias que conseguissem reverter estes defeitos funcionais das DCs seriam potencialmente eficazes na indução de respostas imunes antitumorais. Todavia, estas estratégias esbarravam, até há pouco tempo, com a dificuldade de obtenção de DCs, devido a processos de purificação trabalhosos e de 
baixo rendimento (Steinman, 1981), que impediam o uso clínico destas células. Na última década, porém, após a descrição da possibilidade de diferenciação in vitro deste tipo celular a partir de monócitos do sangue periférico (Sallusto e Lanzavecchia, 1994), inúmeros protocolos têm sido desenvolvidos, procurando explorar as DCs na imunoterapia do câncer (Fukao, 2002; Gabrilovich, 2002; Schuler et al., 2003; Barbuto et al., 2004; Nagaraj et al., 2004; O'Neill et al., 2004; Nencioni e Brossart, 2004; Banchereau e Palucka, 2005; Morse et al., 2005).

Todavia, é importante notar que as alterações funcionais não se restringem apenas as DCs presentes no micro-ambiente tumoral, mas também se manifestam sobre monócitos dos pacientes quando se tenta induzir sua diferenciação in vitro, como nosso laboratório demonstrou em portadores de diferentes neoplasias metastáticas (Neves et al., 2005) ou em pacientes com câncer de mama (Gervais et al., 2005). Embora estratégias alternativas, que buscam contornar estas alterações, venham sendo exploradas (Barbuto et al., 2004; Trefzer et al., 2005), o conhecimento dos mecanismos responsáveis por estas alterações torna-se fundamental para que se atinjam os resultados desejados no tratamento do câncer com DCs.

Por outro lado, a resposta imune não depende apenas de fatores intrínsecos ao sistema imune, ou dependentes da presença do tumor no organismo, mas também de vários outros, fisiológicos ou não. Um deles que parece ter um papel relevante, é o sexo do indivíduo. Já foi demonstrado em experimentos com animais e em humanos que a resposta imune é diferente entre machos e fêmeas (Ansar Ahmed et al., 1985). Mulheres, em geral, apresentam respostas imunes, celular e humoral, mais intensas, são mais resistentes a certas infecções e sofrem mais com doenças autoimunes que os homens (revisado por Ansar Ahmed et al., 1985; 
Bouman et al., 2005). Tais diferenças têm sido relacionadas aos hormônios sexuais femininos, principalmente aos estrógenos, que constituem uma família de hormônios derivados do colesterol. O 17ß-estradiol (E2) é o estrógeno primário de origem ovariana, com maior atividade biológica, que pode ser convertido reversivelmente em estrona (E1) no próprio ovário, no fígado ou em outros tecidos. Ambos, E1 e E2, podem ainda ser convertidos, de maneira irreversível, em estriol (E3), forma com menor atividade hormonal e excretada na urina (Tamaoki, 1973; Kulig, 1994)). No

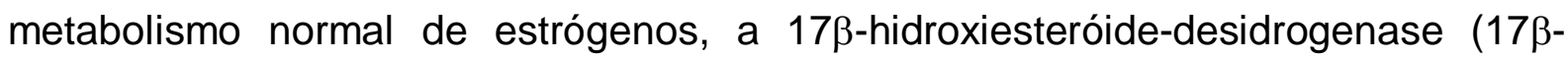
HSD), com seus diferentes tipos, parece ser a enzima responsável pela modulação dos níveis séricos de E1 e E2, desta forma controlando sua atividade biológica (Cheng e Zhou, 2000; Mindnich e Adamski, 2007).

Os estrógenos, principalmente o E2, provocam a maturação das células germinativas, estabelecem a "sincronização hormonal" para a ovulação, estabelecem condições necessárias para manutenção da gestação, influenciam no parto, na amamentação, e com o avançar da idade e a perda de folículos, sua menor produção ocasiona a menopausa (Miller, 1988).

Alguns tipos da 17ß-HSD (tipos 1, 3, 5 e 7) catalisam a reação de redução do hormônio, convertendo E1 em E2 (mais bioativo) e, por sua vez, os tipos 2, 4 e 8 catalisam a reação oxidativa de E2 para E1 (Andersson e Moghrabi, 1997; Sasano et al., 2000). Desequilíbrios da atividade destes tipos da 17 $\beta$-HSD poderiam resultar no aumento significante de uma forma do hormônio em relação à outra causando, desta forma, importantes efeitos biológicos. Assim, é interessante notar que em tumores de mama hormônio-dependentes foi detectada maior expressão da $17 \beta$ HSD tipo 1 (Suzuki et al., 2000), o que, causando um aumento da produção de E2 no ambiente tumoral, provavelmente contribui para o crescimento do tumor. Também 
em outras situações este desequilíbrio pode ocorrer como demonstrado em câncer de cólon, onde este mesmo predomínio, mais uma vez levando ao aumento relativo de E2 em relação a E1, parece contribuir para a patogênese da doença (English et al., 1999).

De qualquer modo, os tumores de mama mesmo já estabelecidos, apresentam, muito freqüentemente, uma dependência importante de estímulos hormonais (Vokaer, 1975; Doisneau-Sixou et al., 2003). Esta condição permite que se utilizem, em seu tratamento, antagonistas e inibidores hormonais com bons resultados clínicos (Fabian, 2001; Bentrem e Craig Jordan, 2002; Yue et al., 2005). Entre estes moduladores, um de uso amplo no tratamento de pacientes com câncer de mama é o tamoxifeno. Esta droga quimicamente definida como (Z)-2-[4-(1,2difenilbut-1-enil)fenoxi]- $N, N$-dimetil-etanamina, foi desenvolvida a partir de estudos sobre a ação endócrina do trifeniletanol. Em meados de 1970, o tamoxifeno passou a ser usado no tratamento de câncer de mama devido sua capacidade de bloquear os receptores de estrógenos no tecido mamário (Jordan, 2006; Powles e Hickish,1995; White, 1999).

No entanto, tanto os estrógenos quanto seus moduladores, como o tamoxifeno, atuam, também, sobre o sistema imune. Especificamente em DCs já foi demonstrada a presença de receptores para estrógeno, capazes de modular sua diferenciação, seu número e sua capacidade funcional (Polanczyk et al., 2004; Paharkova-Vatchkova et al., 2004). Dependendo da condição estudada, esta modulação poderia favorecer a diferenciação das DCs (Paharkova-Vatchkova et al., 2004) ou inibir determinadas funções destas células (Polanczyk et al., 2004). Em concordância com tal fato, também inibidores de estrógenos afetam a diferenciação de DCs, ao menos in vitro, de maneira geral inibindo este processo (Komi e Lassila, 
2000). Aparentemente em desacordo com estes dados, mas confirmando a heterogeneidade dos efeitos de estrógenos sobre as DCs, Lang (2004) revê o efeito dos estrógenos sobre as DCs, sugerindo que sob o efeito destes hormônios, estas células se tornam estimuladoras preferenciais de linfócitos T do padrão Th2.

Assim, é possível enumerar vários fatores capazes de afetar a função de DCs em pacientes com câncer: pH e citocinas produzidas no micro-ambiente, produtos das células tumorais, hormônios produzidos localmente ou à distância e metabolizados localmente, drogas usadas no tratamento dos pacientes, e assim por diante. No presente trabalho, portanto, pretendemos aprofundar a análise dos efeitos de alguns fatores que participam da composição do microambiente tumoral, como a precença das células tumorais e seu fatores soluveis, moduladores de estrógenos (drogas de uso praticamente obrigatório em boa parcela das pacientes com tal neoplasia) e do pH ácido causado pela alta concentração de lactato no meio (condição comum à maioria das neoplasias) sobre as DCs, tanto de indivíduos sadios quanto de pacientes portadoras de carcinoma de mama ductal invasivo. 
2 OBJETIVOS 


\subsection{Geral}

Avaliar alguns aspectos presentes no microambiente tumoral, como a interação entre modulador de receptor de estrógenos (tamoxifeno), de lactato e do inibidor da p38MAPKsobre a diferenciação e maturação de DCs derivadas in vitro a partir de monócitos do sangue periférico de voluntárias saudáveis e de pacientes portadoras de carcinoma ductal invasivo. Também estes mesmos efeitos serão avaliados em co-cultura das DCs com células de duas linhagens de carcinoma mamário humano, uma dependente (MCF-7) e outra independente de estrógeno (SK-BR-3).

\subsection{Específicos}

Avaliar, nas diferentes condições, a expressão dos marcadores de membrana CD1a, CD11c, CD14, CD40, CD80, CD83, CD86, CCR7 e HLA-DR nas DCs diferenciadas in vitro.

Investigar a capacidade das DCs, obtidas nas diferentes condições, de induzir proliferação de linfócitos alogenéicos e o padrão de citocinas produzido nas diferentes culturas.

Investigar a expressão da HSP27 nas DCs obtidas nas diferentes condições.

Determinar, por citometria de fluxo, a presença de DCs infiltradas no tumor.

Avaliar por imunohistoquímica, o fenótipo de DCs infiltradas no tecido tumoral de pacientes e correlacionar o fenótipo das DCs com aspectos anatomopatológicos do tumor da paciente. 
3 MATERIAL E MÉTODOS 


\subsection{Casuística}

Foram selecionadas para o estudo vinte pacientes do sexo feminino, com idade entre 34 e 83 anos, que apresentaram diagnóstico de carcinoma ductal invasivo de mama, ainda não tratado, e candidatas à mastectomia radical modificada. Diagnóstico de carcinoma lobular e/ou tratamento quimioterápico prévio à cirurgia foram considerados como critérios de exclusão. Outro grupo que participou do estudo foi formado por seis pacientes atendidas no ambulatório, diagnosticadas com carcinoma ductal que já haviam feito a cirurgia de retirada do tumor, e que vinham fazendo uso de tamoxifeno por, no mínimo, seis meses.

Todas as pacientes foram informadas sobre o estudo proposto e após a assinatura do termo de consentimento livre e esclarecido foram incluídas no estudo, aprovado previamente pelo Comitê de Ética em Pesquisa do Instituto de Ciencias Biomédicas-USP (Parecer 695/CEP) e na Direção de Ensino do Hospital Pérola Byington (número 107/06).

Para o grupo controle, desoito voluntárias saudáveis (com 32 a 50 anos de idade) foram recrutadas para o estudo, também, após assinatura do termo de consentimento livre e esclarecido.

Nos três grupos de estudo foram feitas as coletas do sangue periférico para a realização da cultura de diferenciação de DCs a partir de células mononucleares (PBMCs). A coleta do fragmento de tumor e a análise de imunoistoquímica foi realizado apenas no grupo de pacientes portadoras de carcinoma ductal invasivo, submetidas a mastectomia. 
As características clínicas e anatomopatológicas dos tumores das pacientes com carcinoma ductal que participaram deste estudo estão expostas na tabela 1 e das pacientes ambulatoriais tratadas com tamoxifeno, sem tumor, na tabela 2.

Tabela 1- Estadiamento clínico e determinação anatomopatológica dos marcadores tumorais, receptor de estrógeno (ER), receptor de progesterona (PR) e c-erb-B2, nas pacientes com carcinoma ductal invasivo antes da mastectomia.

\begin{tabular}{|c|c|c|c|c|c|}
\hline \multirow[t]{2}{*}{ Paciente } & \multirow[t]{2}{*}{ Idade } & \multirow[t]{2}{*}{ Classificação TNM } & \multicolumn{3}{|c|}{ Marcadores de prognóstico } \\
\hline & & & ER & PR & c-erb-B2 \\
\hline 01 & 64 & T1 N0 & + & + & - \\
\hline 02 & 54 & Tis & ID & ID & ID \\
\hline 03 & 55 & Tis & + & - & - \\
\hline 04 & 81 & T2 No & + & - & ++ \\
\hline 05 & 81 & T2 N1 & - & - & - \\
\hline 06 & 48 & T3 N1 & - & - & - \\
\hline 07 & 47 & T4d N2 & - & - & +++ \\
\hline 08 & 34 & T2 N1 & - & - & +++ \\
\hline 09 & 81 & T2 No & + & + & - \\
\hline 10 & 50 & T4b N1 & - & - & - \\
\hline 11 & 72 & T2 No & + & - & - \\
\hline 12 & 71 & T2 No & + & - & - \\
\hline 13 & 34 & T2 No & + & - & +++ \\
\hline 14 & 52 & $\mathrm{TX}$ & ID & ID & ID \\
\hline 15 & 83 & T2 No & + & + & - \\
\hline 16 & 69 & T1 N1 & + & + & - \\
\hline 17 & 57 & TI NO & + & + & - \\
\hline 18 & 48 & TX & + & + & - \\
\hline 19 & 62 & T0 & + & - & - \\
\hline 20 & 41 & T2 No & ID & ID & ID \\
\hline
\end{tabular}


Tabela 2- Estadiamento clínico e determinação anatomopatológica dos marcadores tumorais, receptor de estrógeno (ER), receptor de progesterona (PR) e c-erb-B2, nas pacientes em tratamento ambulatorial com Tamoxifeno.

\begin{tabular}{|c|c|c|c|c|c|}
\hline \multirow[t]{2}{*}{ Paciente } & \multirow[t]{2}{*}{ Idade } & \multirow[t]{2}{*}{ Classificação TNM } & \multicolumn{3}{|c|}{ Marcadores de prognóstico } \\
\hline & & & ER & PR & c-erb-B2 \\
\hline 01 & 47 & T2 N0 & + & + & - \\
\hline 02 & 57 & T2 No & + & - & - \\
\hline 03 & 71 & T1 No & + & - & - \\
\hline 04 & 50 & T0 & ID & ID & ID \\
\hline 05 & 34 & T3 N1 & + & + & - \\
\hline 06 & 65 & T3 N0 & + & + & - \\
\hline
\end{tabular}

\subsection{Coleta do tumor}

As pacientes encaminhadas para a cirurgia de mastectomia radical modificada tiveram a peça anatomopatológica removida e levada para o laboratório de patologia do Hospital Pérola Byington onde foi realizada a coleta de material. Para imunohistoquímica, a coleta seguiu o protocolo de procedimentos do setor de patologia do próprio hospital, e para citometria de fluxo, uma amostra de tumor foi colocada em meio RPMI-1640 (Gibco BRL) e encaminhada para o laboratório de Imunologia de Tumores (ICB-USP) para realização da digestão por colagenase e análise por citometria de fluxo.

\subsection{Imunohistoquimica}

A análise de imunohistoquimica foi realizada de acordo com o protocolo de rotina do setor de Anatomia Patológica do Hospital Pérola Byington, onde, os cortes histológicos foram obtidos de fragmentos do tumor retirados dos pacientes emblocados com parafina onde foram feitos corte de $3 \mu \mathrm{m}$ de espessura por meio de 
micrótomo. Os cortes foram colocados em laminas de vidro preparadas com organossilado para analise histoquímica. Na analise imunohistoquimica, os cortes obtidos foram colocados em laminas de vidro e preparadas com adesivo a base de 3-aminopropil-trietoxi-silano (Sigma Chemical Co, St Louis, MO USA). Posteriormente os cortes ficaram incubados por 24 horas em estufa a $55^{\circ} \mathrm{C}$ e sofreram três banhos de xilol a $60^{\circ} \mathrm{C}, 55^{\circ} \mathrm{C}$ e a temperatura ambiente, durante 60 , 30 e 20 minutos, respectivamente, para remoção da parafina. A hidratação foi realizada com concentrações decrescentes de etanol, seguidos por lavagens em água corrente. $\mathrm{O}$ bloqueio da peroxidase tecidual endógena foi feita por meio de imersão dos cortes, por quatro minutos, em tampão de citrato sob aquecimento, seguido de um resfriamento por vinte minutos. Novamente os cortes passaram por outra seqüência de três banhos em água corrente por cinco minutos, três banhos em água destilada por cinco minutos, quatro banhos com peróxido de hidrogênio em câmara escura, três banhos em água corrente por cinco minutos, três banhos em água destilada por cinco minutos e três banhos em solução salina tamponada com fosfato $\mathrm{pH}=7,2$ (PBS) por cinco minutos. Os cortes foram bloqueados com Protein Block (Dako) por dez minutos. Em seguida, a expressão dos marcadores CD68 (marcador de macrófagos), CD14 (marcador de monócitos e macrofagos), proteína S-100 (marcadora de DCs) e CD1a (marcadora de subpopulação de DCs) foram avaliados com auxílio da streptoavidina-biotina-imunoperoxidase. Os cortes foram submetidos à incubação "overnight" com os anticorpos primários, CD68 (Dako, monoclonal \# PG-M1) CD14 (Dako, monoclonal \# UCH-M1), proteína S-100 (Dako, policlonal) e CD1a (Santa Cruz, monoclonal \# CTB6), nas diluições 1/1000, 1/150, 1/3000 e 1/500 em PBS com 1\% de albumina sérica bovina, respectivamente. Os cortes passaram por dois banhos em PBS por cinco minutos. Os cortes foram 
incubados com um polímero de detecção Mach1 Mouse Probe (Biocare Medicine) em câmara escura, por trinta minutos. Após duas lavagens em PBS, por cinco minutos, os cortes foram incubados, em camara escura, com anticorpo secundário de cabra anti-espécie biotinilado, em solução pronta para uso (LSAB) (Dako, CA, USA) por trinta minutos e lavados duas vezes com tampão PBS por 5 minutos. Posteriormente foi aplicado o complexo streptoavidina-biotina-peroxidase em solução pronta para uso (Dako, CA, USA), durante 30 minutos em câmara úmida a $37^{\circ} \mathrm{C}$. Para a revelação foi usada a solução de diaminobenzidina (Sigma) em PBS (12,5 mg de diaminobenzidina para cada $12,5 \mathrm{~mL}$ de PBS) por cinco minutos em estufa a $37^{\circ} \mathrm{C}$. A análise das lâminas foi feita por microscopia óptica em aumento de 200x. Nas amostras de 10 pacientes, as células marcadas foram quantificadas através da frequência determinada pelo coeficiente do número de células marcadas x 100/ número total de núcleos por campo, tomando-se a média de 10 campos/paciente, utilizando o programa ImageJ.

\subsection{Processamento do tumor por colagenase}

As amostras de tumor fresco foram pesadas em placa de Petri, posteriormente, foram cortadas em pequenos fragmentos com auxílio de bisturi. Os fragmentos foram colocados em vidros estéreis com tampa e adicionados $5 \mathrm{~mL}$ de meio RPMI 1640 por grama de tecido e colagense (Tipo VIII/ $0.056 \mathrm{mg} / \mathrm{mL}$ ) na proporção de $500 \mu \mathrm{L}$ de enzima para cada $9,5 \mathrm{~mL}$ de meio. A suspensão foi levada para o banho-maria a $37^{\circ} \mathrm{C}$ por 2 horas. Após a completa digestão do tumor, a suspensão foi filtrada com o auxílio de uma seringa (sem o êmbolo) com gaze estéril embebida em RPMI 1640. As células foram contadas em uma câmara de Neubauer, 
destas, $2 \times 10^{5}$ células tumorais foram centrifugadas e o pellet ressuspenso para a análise fenotípica segundo o item 3.7.

\subsection{Obtenção das amostras de sangue periférico}

A coleta do sangue periférico (tanto das pacientes quanto das voluntárias) foi feita por punção venosa, obtendo-se um volume final médio de $25 \mathrm{~mL}$ de sangue, através da utilização de tubos a vácuo contendo etilenodiaminotetracético (EDTA) como anticoagulante (BD Vacutainer Systems).

\subsection{Isolamento de monócitos e diferenciação em DCs}

As PBMCs foram obtidas colocando-se o sangue coletado das pacientes diluído com PBS (1:2) em tubos plásticos cônicos de $50 \mathrm{~mL}$, aos quais foram acrescentados, no fundo do tubo, $12 \mathrm{~mL}$ de Ficoll-Paque (Amersham Biosciences). O material foi centrifugado a $607 \mathrm{~g}$ por 30 minutos, a $18^{\circ} \mathrm{C}$. A camada de células mononucleares formada foi retirada, colocada em outro tubo juntamente com HBSS (Hanks Balanced Salt Solution) e centrifugada a $290 \mathrm{~g}$ por $10 \mathrm{~min}$. As células foram lavadas por mais duas vezes a $244 \mathrm{~g}$ e $200 \mathrm{~g}$, respectivamente, para eliminação das plaquetas. O "pellet" foi coletado, as PBMCs foram quantificadas, ressuspendidas em meio AIM-V (Gibco BRL, meio de cultura livre de soro). Uma amostra de $2 \times 10^{5}$ das PBMCs foi separada para análise fenotípica, como descrito no item 3.7 e o restante das células foi mantido em cultura, na concentração de $2 \times 10^{6} / \mathrm{mL}$. As células foram mantidas em estufa de $\mathrm{CO}_{2}$ "overnight" a $37^{\circ} \mathrm{C}$, para aderência em placas de plástico.

Após esse período, as células não-aderentes foram separadas e congeladas em nitrogênio líquido na concentração de $1 \times 10^{7}$ células $/ \mathrm{mL}$ em soro fetal bovino 
(SFB) com 10\% de Dimetilsufóxido (DMSO) e as aderentes cultivadas por 7 dias em meio AIM-V acrescido de $50 \mathrm{ng} / \mathrm{mL}$ de IL-4 e $50 \mathrm{ng} / \mathrm{mL}$ de GM-CSF. No quinto dia, as células foram estimuladas para maturação com $50 \mathrm{ng} / \mathrm{mL}$ de TNF- $\alpha$ por mais dois dias.

Após o período de cultura, as placas foram submetidas a um banho de gelo por 5 minutos, para facilitar a retirada e coleta das células fracamente aderentes. Estas foram lavadas e sua viabilidade testada por sua capacidade de excluir o Azul de Trypan $(0,4 \%)$.

As diferentes condições foram aplicadas sobre este protocolo básico. Assim, tamoxifeno $10 \mathrm{mM}$ (Sigma) foram acrescentados no dia zero da cultura, bem como solução de lactato 15 mM. Esta concentração foi estabelecida após ensaios com uma curva de $\mathrm{pH}$, onde nesta concentração $\circ \mathrm{pH}$ foi de 6,9 , não havendo redução significativa no rendimento (Figura 1). O tratamento com SB203580 $10 \mu \mathrm{M}$, inibidor da via p38MAPK, foi realizado sobre as células aderentes no dia zero por trinta minutos, após esse período o poço foi lavado delicadamente duas vezes com meio RPMI e adicionado às células em cultura o meio AIM-V ou AIM-V acidificado com lactato $15 \mathrm{mM}$. A co-cultura com as linhagens MCF-7 e SK-BR-3 foi feita no quinto dia da cultura na proporção de uma célula tumoral para 30 células aderentes submetidas à diferenciação. Foram feitos dois ensaios, um utilizando células tumorais viáveis mantidas em cultura com as DCs através de placas de cultura tipo trans-well ou utilizando-se células tumorais irradiadas (12,5 Gy) acrescentadas diretamente à cultura de DCs em placa de cultura comum. Em todas as situações, células não-estimuladas foram usadas como controle. 


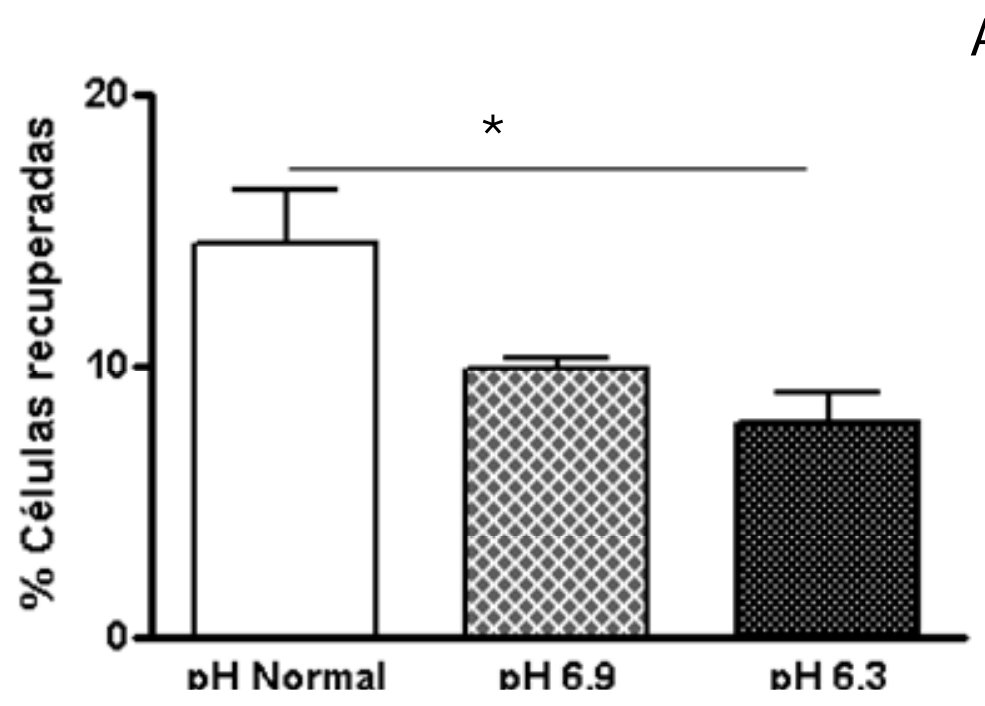

A

HLA-DR

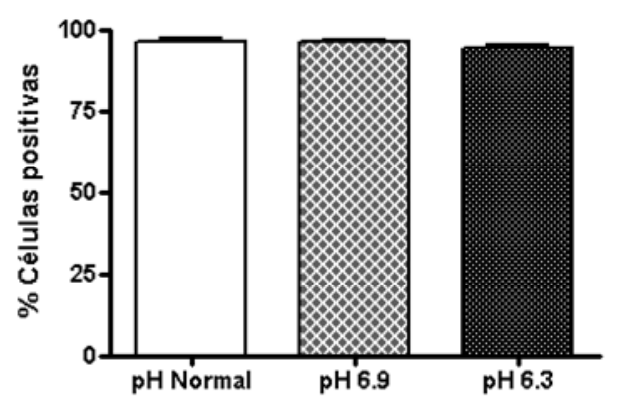

CD86

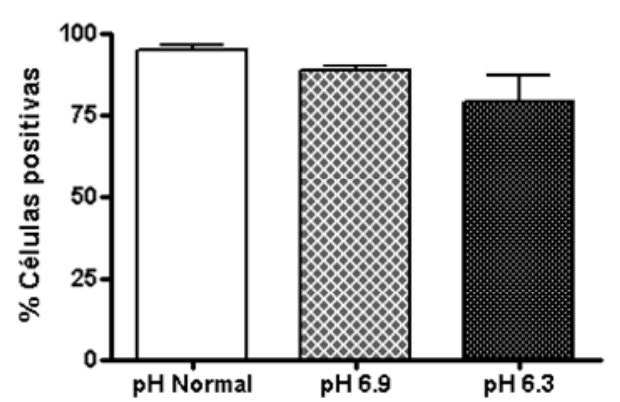

B

CD11c

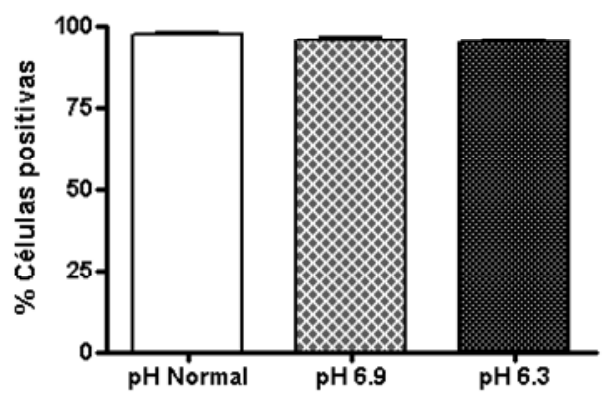

CD80

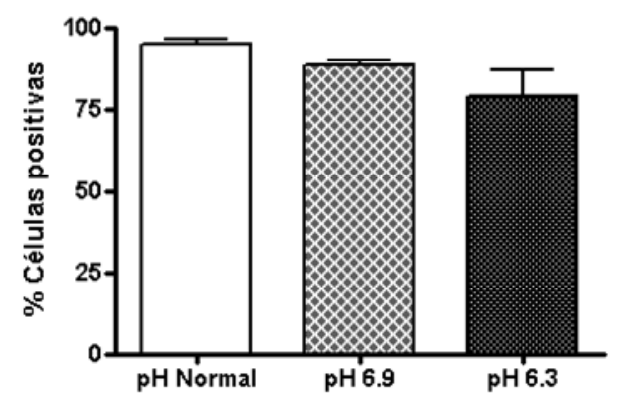

Figura 1- Efeito de acidificação do meio na diferencia ção das DCs. (A) Frequência de células recuperadas na cultura em $\mathrm{pH}$ normal, $\mathrm{pH6}, 9$ e pH6,3. (B)Freqüência de células positvas para HLA-DR, CD11c, CD86 e CD80 em DCs derivadas de PBMCs.Análise feita pelo teste ANOVA e pós-teste de Bonferroni. ${ }^{*}=p<0,05$ 
O rendimento da cultura foi calculado através da frequência de DCs obtidas no final da cultura em relação do número total de PBMCs plaqueadas (número de DCs $\times 100$ / número total de PBMCs plaqueadas) ou do número total de PBMCs CD14+ (número de DCs x 100 / número total de PBMCs CD14+) ou do número de células aderidas (número de DCs x 100 / número de células aderidas).

\subsection{Estudo fenotípico por citometria de fluxo}

Para determinação do fenótipo de membrana, as células foram marcadas com anticorpos monoclonais comerciais (CALTAG Lab) contra os seguintes marcadores: CD11c (marcador de DCs mielóides), CD80 (B7-1, molécula co-estimuladora), CD83 (marcador de DCs ativadas/maduras), CD86 (B7-2, molécula co-estimuladora), CD1a (marcador de DCs derivadas de monócitos in vitro), CD14 (marcador de monócitos e macrófagos, ausente em DCs), HLA-DR (MHC classe II), HLA-ABC (MHC classe I), CCR7 (receptor para quimiocinas, expresso por DCs ativadas/maduras - R \& D Systems).

Após contagem, alíquotas de $5 \times 10^{5}$ células foram colocadas em tubos plásticos (Eppendorf) de 1,5mL e centrifugadas por $5 \mathrm{~min}$, a $290 \mathrm{~g} \mathrm{e} 4{ }^{\circ} \mathrm{C}$ para obtenção de um "pellet", ao qual foram adicionados anticorpos específicos para os marcadores de interesse. As células foram incubadas por 20 min a $4{ }^{\circ} \mathrm{C}$ ao abrigo da luz. Após este período, o material foi lavado por 2 vezes $\left(5 \mathrm{~min}, 290 \mathrm{~g}, 4^{\circ} \mathrm{C}\right) \mathrm{com}$ $500 \mu \mathrm{L}$ de tampão para citometria (PBS suplementado com $0,5 \%$ de soroalbumina bovina e 0,02\% de azida sódica). Após as lavagens, as células, já marcadas, foram ressuspendidas em $500 \mu \mathrm{L}$ de tampão para citometria e analisadas no citômetro de fluxo (FACSCalibur). Os dados obtidos foram analisados usando-se o "software" FlowJo. 


\subsection{Identificação do "gate” para análise das DCs}

As células mononucleares obtidas do sangue periférico (PBMCs) de voluntárias saudáveis e de pacientes com carcinoma mamário foram submetidas à cultura suplementada com IL-4, GM-CSF e TNF- $\alpha$, por sete dias, para a sua diferenciação em DCs maduras. Para verificar se a diferenciação foi efetiva, as células obtidas no final da cultura foram avaliadas com base na expressão de alguns marcadores de membrana. Para isso foi utilizado um conjunto de marcadores de linhagens específicas (CD3 - marcador de linfócitos T e timócitos; CD14 - presente em monócitos e macrófagos; CD56 - expresso em células "natural killer") e os marcadores, Antígeno Leucocitário Humano DR (HLA-DR) e CD11c. Com este conjunto, caracterizaram-se as DCs como células "Linhagens"- (Lin-) e HLA$\mathrm{DR}+\mathrm{CD} 11 \mathrm{C}+$.

A análise por citometria de fluxo das células recuperadas ao término da cultura mostrou razoável heterogeneidade morfológica das células, mas com uma população com tamanho e granulosidade típicos de DCs (Figura 2A). Estas células foram analisadas quando à expressão dos marcadores de linhagens específicas e as células Lin- (Figura 2B) foram selecionadas e, então, analisadas quanto à expressão de HLA-DR e CD11c (Figura 2C). Como se pode notar na figura 1D, as células HLA-DR+CD11C+Lin- apresentavam as características de tamanho (FSC) e granulosidade (SSC) tipicamente atribuídas às DCs. Devido à esta sobreposição de parâmetros "morfológicos" (tamanho e granulosidade) e padrão de expressão do conjunto de marcadores típicos, ao longo deste estudo demos preferência aos parâmetros "morfológicos" para seleção das populações a serem estudadas. 
A

B

C
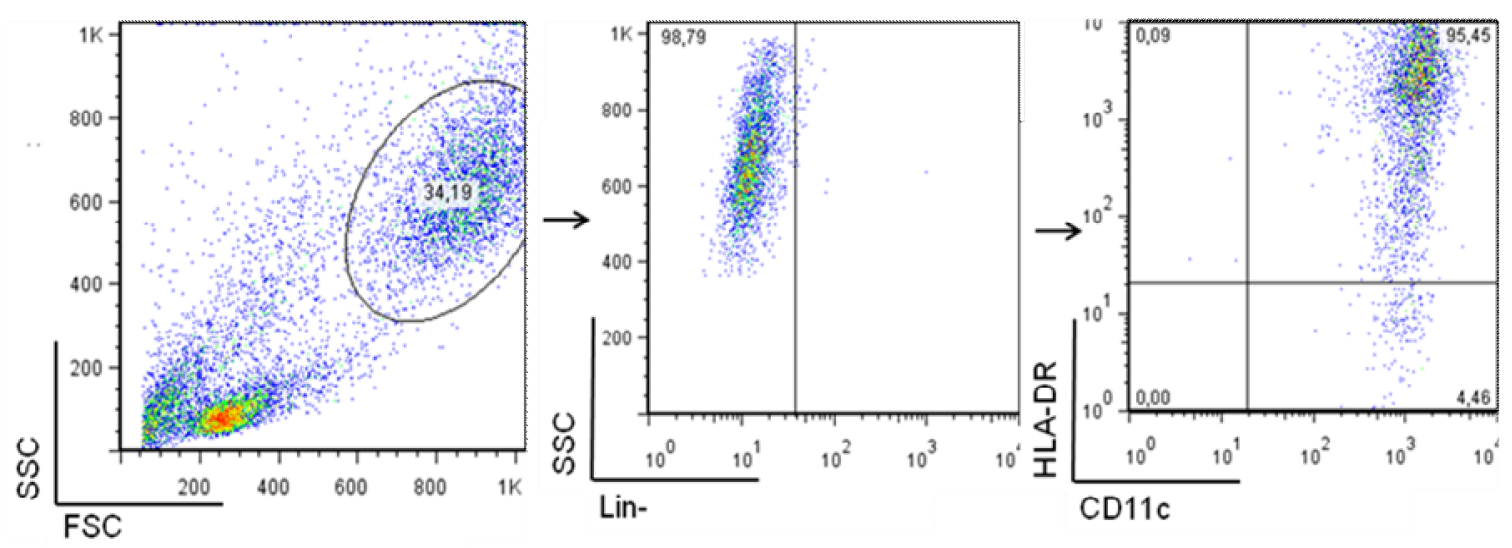

Figura 2- Gráficos representativos das células obtidas na cultura de diferenciação de células PBMCs em DCs. (A) População celular analisadas por citomeria de fluxo selecionada uma população grande e granulosa. (B) Esta população não expressava CD3, CD14,CD56 ou Lineage negative ( $L n)$. (C) A população $L n$ foi selecionada e analisada a expressão de $\mathrm{HLA}^{-D R^{+}}$e CD11c ${ }^{+}$. (D) A população Ln HLA-DR ${ }^{+} \mathrm{CD} 11 \mathrm{c}^{+}$quando analisada por SSC e FSC apresentou maior de tamanho e granulosidade.

\subsection{Separação de Linfócitos T}

Linfócitos $T$ alogenéicos foram usados como células respondedoras em culturas mistas e foram separados por sua capacidade de formar rosetas com hemácias de carneiro, como descrito por Saxon et al. (1976). As hemácias de carneiro foram colocadas em um tubo plástico estéril de $50 \mathrm{~mL}$ e centrifugadas a 290 g durante 10 minutos a $20{ }^{\circ} \mathrm{C}$, e a seguir lavados 2 vezes, com mesma centrifugação, em tampão PBS. Estas hemácias foram tratadas com AET (2aminoethylisothiouronium bromide hydrobromide; Sigma) para mudar a carga elétrica da superfície das hemácias, possibilitando uma maior interação eletrostática com linfócitos $\mathrm{T}$ e a formação de rosetas estáveis. Para tanto, foram diluídos $0,5 \mathrm{~g}$ de AET em 12,5 mL de água bidestilada e deionizada, com ajuste final do $\mathrm{pH}$ para 9,0 utilizando-se $\mathrm{NaOH}$ 1,0 N. Após passagem em filtro de 0,22 $\mu \mathrm{m}$ (Millipore), $8 \mathrm{~mL}$ de solução de AET foram acrescentados a cada $2 \mathrm{~mL}$ de "papa" de hemácias de carneiro e mantidos durante 20 a 40 minutos a $37^{\circ} \mathrm{C}$. 
A seguir, as hemácias foram lavadas com tampão PBS, pH 7,2 (centrifugação a $435 \mathrm{~g}$ por 10 minutos), até obtenção de sobrenadante claro e ressuspensas até se obter uma suspensão a 4\% em meio RPMI-1640 suplementado com SFB a $10 \%$ (R10).

Uma suspensão de linfócitos em concentração máxima de $1 \times 10^{7}$ células $/ \mathrm{mL}$ foi preparada, misturada com soro fetal bovino e hemácias de carneiro pré-tratadas com AET (preparação AET-SRBC) como descrito anteriormente, numa proporção de 2:1:2, centrifugada a $193 \mathrm{~g}$, por 5 minutos a $4^{\circ} \mathrm{C}$ e incubada em gelo por 1 hora. Após a incubação, as células foram novamente ressuspensas e o número de rosetas contado. A suspensão foi submetida à centrifugação sobre Ficoll-paque (2100 rpm, 4 ${ }^{\circ} \mathrm{C}, 35$ minutos).

Após a centrifugação, os linfócitos T ficaram no "pellet", no fundo do tubo, formando rosetas com as hemácias de carneiro modificadas. Os linfócitos T foram recuperados com tampão de lise de hemácias e lavados em meio de cultura R-10, com centrifugação a $314 \mathrm{~g}$, durante 10 minutos a $20{ }^{\circ} \mathrm{C}$. Os linfócitos $\mathrm{T}$ foram ressuspensos em meio R-10, quantificados em câmara de Neubauer, e sua concentração ajustada.

\subsection{Avaliação da atividade aloestimuladora das DCs}

Para avaliar a capacidade aloestimuladora das células geradas, diferentes concentrações de DCs irradiadas (12,5 Gy) foram co-cultivadas com linfócitos T alogenéicos $\left(1 \times 10^{5}\right.$ células $/ \mathrm{mL}$ ) em um volume final de $100 \mu \mathrm{L} /$ poço em placas de cultura de 96 poços. As células foram mantidas por 5 dias em estufa com atmosfera contendo $5 \%$ de $\mathrm{CO}_{2}$ e saturada de água, a $37 \stackrel{\circ}{\circ}$, quando a resposta linfocitária foi avaliada. 
Para avaliação da proliferação celular, os linfócitos $T$ foram incubados em tampão PBS-BSA 0,1\%, contendo $5 \mu \mathrm{M}$ de CFSE (Lyons, 2000). A incubação foi feita a $37{ }^{\circ} \mathrm{C}$, no escuro, por $20 \mathrm{~min}$. Após este período, as células foram lavadas 2 vezes em meio RPMI, suplementado com $3 \%$ de soro bovino fetal. Os linfócitos foram, então, co-cultivados com DCs e avaliados por citometria de fluxo. Os valores foram analisados pelo "software" FlowJo e comparados a partir do índice de proliferaçào calculado pelo coeficiente da Intensidade de Fluorescencia (MFI) do CFSE do linfócito isolado pelo MFI do CFSE de linfócitos mantidos em co-cultura com DCs.

\subsection{Detecção da produção de citocinas por ensaio imunoenzimático (ELISA)}

Para detecção de citocinas nos sobrenadantes das culturas foram utilizados os kits DuoSets para citocinas (R\&D Systems, Minneapolis, MN, EUA). Neste método, placas de 96 poços Maxisorp (Nunc) foram sensibilizadas com $50 \mu \mathrm{L} /$ poço do anticorpo (Ac) de captura, diluído em tampão de carbonato (0,1 M Carbonato de sódio, $\mathrm{pH}$ 9,5) e mantido a $4 \stackrel{\circ}{\circ} \mathrm{C}$ "overnight". Após 3 lavagens com $200 \mu \mathrm{L} /$ poço de tampão de lavagem (PBS contendo 0,05\% de Tween 20, pH 7,2), as placas foram bloqueadas com $200 \mu \mathrm{L} /$ poço de tampão de bloqueio (PBS contendo 10\% SFB) por 1 hora a temperatura ambiente. Em seguida, após 3 lavagens, as amostras e a curva-padrão foram incubadas por um período de 2 horas em temperatura ambiente. As amostras para dosagem foram diluídas 1:2 em. Para a curva-padrão, as citocinas recombinantes foram incubadas em duplicatas de $45 \mu \mathrm{L}$ por poço das diluições seriadas (fator 2 de diluição), conforme recomendações do fabricante. O período de incubação das amostras e da curva padrão foi de 2 horas à temperatura ambiente. 
Após três lavagens, foram adicionados $50 \mu \mathrm{L} /$ poço do anticorpo de detecção (175 $\mathrm{ng} / \mathrm{mL}$ diluído em tampão de diluição) e seguiu-se nova incubação por 2 horas à temperatura ambiente. Novamente a placa foi lavada 3 vezes e $50 \mu \mathrm{L} /$ poço de estreptoavidina diluída em tampão de diluição foram adicionados e havendo nova incubação por 1 hora, no escuro, à temperatura ambiente. Após esse período e 7 novas lavagens, $50 \mu \mathrm{L}$ /poço de substrato $\left(\mathrm{H}_{2} \mathrm{O}_{2}\right.$ e tetrametilbenzidina, $\mathrm{R} \& \mathrm{D}$ System $)$ foram adicionados, com incubação de 30 min, no escuro, em temperatura ambiente. Por fim, $50 \mu \mathrm{L} /$ poço de $\mathrm{H}_{2} \mathrm{SO}_{4}$ (2N) foram adicionados para interromper a reação e a densidade óptica foi determinada em espectrofotômetro com filtro de $450 \mathrm{~nm}$. O cálculo das concentrações foi feito com auxílio do "software" Softmax Pro, através da equação de regressão linear com base na curva padrão e a análise de dados foi executada com auxílio do "software" Prisma.

\subsection{Extração de RNA}

Os experimentos descritos neste e no próximo ítem foram realizados seguindo os protocolos utilizados pelo laboratório de genética do Departamento de Radiologia-FMUSP. Após a mastectomia das pacientes, as amostras de tumor coletadas foram congeladas em nitrogênio líquido para posterior extração de RNA. Os tecidos congelados foram pulverizados utilizando um pulverizador de tecido congelado (Termovac). A extração do RNA do tumor foi feita de acordo com o método descrito por Chomczynski e Sacchi (1987). O kit Illustra RNAspin min isolation (GE healthcare, Piscataway, USA) foi utilizado para extração de RNA de DCs. As amostras de DCs obtidas no sétimo dia foram removidas da placa de cultura e colocadas em um tubo de 1,5 mL. Em seguida, foi feito um "spin" e o 
sobrenadante foi removido. Ao precipitado foi adicionado o tampão de lise, de acordo com os procedimentos de extração descritos pelo fabricante.

A concentração de RNA total extraído foi determinada por leitura espectrofotométrica a 260/280 nm no geneQuant pro (Amersham Biosciences, Cambridge, Inglaterra) e a qualidade do RNA foi avaliada através da eletroforese em gel de agarose $1 \%$ com formadeído marcada com brometo de etídio $1,0 \mathrm{mg} / \mathrm{ml}$. Todas as amostras de RNA foram tratadas com Dnase I (Promega, Madison, EUA)

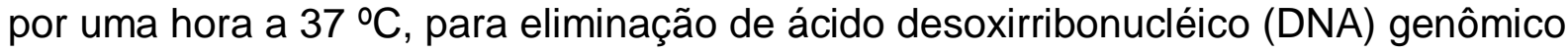
contaminante.

\subsection{Síntese de cDNA e PCR quantitativa em tempo real (qPCR)}

O cDNA foi gerado a partir de $10 \mu \mathrm{g}$ de RNA total tratado com DNAse RNAsefree $1 \mathrm{U} / \mu \mathrm{l}$ (Promega) utilizando o kit High Capacity cDNA Archive (Applied Biosystems, Warriton, UK) conforme orientação do fabricante.

A qPCR foi feita usando $1 \mu \mathrm{L}$ de cDNA, diluído 1:5, em duplicata do gene controle GADPH e do gene de interesse (HSP27). As amplificações (40 ciclos) foram realizadas no equipamento GeneAmp 7500 Sequence Detection System (Applied Biosystems, Califórnia, EUA) através do Power SYBR Green Master Mix (Applied Biosystems, Warriton, UK). Para as amostras de tumor de mama foram usados os primers: GAPDH, forward primer 5'-CCTCCAAAAT CAAGTGGGGCG-3' e reverse primer 5'-GGGGCAGAGATGATGACCCTT-3' e HSP27, forwad primer 5'AGATGTAGCCATGCTCGTCCT-3' e reverse primer 5'GTCCCTGGATGTCAACCACT-3'. A expressão relativa do gene foi determinada usando a expressão do GADPH como gene de referência e um "pool" obtido de 10 
amostras de tecido normal de mama como controle. Para as amostras de DCs, os primers usados foram: $\beta$-actina, forwad primer 5'-TGC CCTGGCACCCAGCACAA-3' e reverse primer 5'-GGGCCGGACTCGTCA TACTC-3' e HSP27, com a sequencia do primer descrito acima. A expressão relativa do gene foi determinada usando a expressão do $\beta$-actina como gene de referência e as amostras de cultura de DCs sem tratamento como controle.

A expressão relativa foi calculada pela fórmula $2^{-\Delta \Delta C T}(C T=$ valor limiar de fluorescencia; $\Delta \mathrm{CT}=\mathrm{CT}$ do gene alvo - $\mathrm{CT}$ do gene de referência; $\Delta \Delta \mathrm{CT}=\Delta \mathrm{CT}$ do gene alvo nas amostras - $\triangle \mathrm{CT}$ do gene alvo nos controles).

\subsection{Análise estatística}

As análises estatísticas foram realizadas no programa GraphPad Prism versão para Windows (GraphPad Software, San Diego California USA). As amostras que apresentaram uma distribuição normal (Gaussiana) os resultados foram expressos pela média dos valores maios ou menos a média do erro padrão. As comparações entre as frequências dos marcadores celulares antes e depois da cultura de diferenciação, do mesmo indivíduo, foram feitas pelo teste t pareado. $\mathrm{O}$ teste t não-pareado foi utilizado nas análises comparativas entre voluntárias e pacientes, bem como na anailse da frequência dos marcadores de DCs em tecido tumoral. Nas análises de comparação entre três grupos ou tratamentos diferentes foi utilizado o teste de variância ANOVA com pós teste de Bonferroni. Os resultados foram considerados como estatisticamente diferentes quando o valor de $p<0,05$. 
4 RESULTADOS 


\subsection{Análise de DCs infiltradas no tumor}

As células obtidas das amostras de tumor digeridas com colagenase foram usadas para análise fenotípica utilizando os mesmos marcadores de membrana aplicados para a caracterização de DCs, com o objetivo de pesquisar a presença destas células infiltradas no tumor. Os resultados mostraram uma freqüência relativamente alta de células $\operatorname{CD}^{+}(28,44 \%)$ enquanto a freqüência de células expressando outros marcadores de DCs (HLA-DR, CD1a, CD86, CD40, CD11c, CCR-7, CD80 e CD123) ou de monócitos/macrófagos (CD14) foi muito baixa (Figura 3). Na cultura primária, as células tumorais sobreviveram em cultura apenas por aproximadamente cinco dias. Foi observado que as células obtidas do tumor digerido apresentaram menor viabilidade que as células desprendidas espontaneamente do fragmento do tumor mantido em meio de cultura.

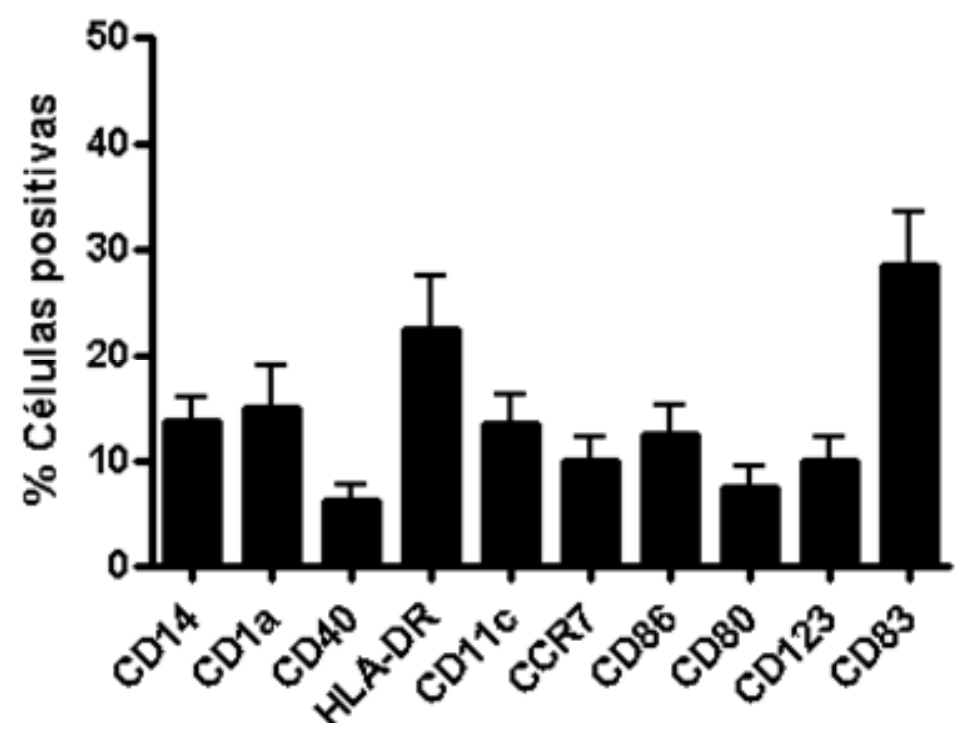

Figura 3- Análise fenotípica de marcadores celulares para caracterização de DCs em suspensão de células obtidas do tecido tumoral digerido com colagenase. As análises estatísticas foram realizadas pelo teste t não pareado. 


\subsection{Imunohistoquímica de marcadores de células imunes presentes nos carcinomas mamários}

Amostras de tumor foram utilizadas para verificar a presença de células que expressam S100 (marcador de DCs), CD68 (marcador de macrófagos) e CD14 (marcador de monócitos e macrófagos) por imunohistoquímica. Os resultados mostraram que a frequência de células $S 100$ positivas foi maior $(59,7 \pm 3 n=10)$

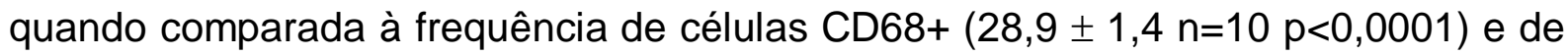
células CD14+ $(26,9 \pm 6,6 n=10 ; p<0,0001)$, localizadas nas áreas intra e peritumoral (Figura 4).

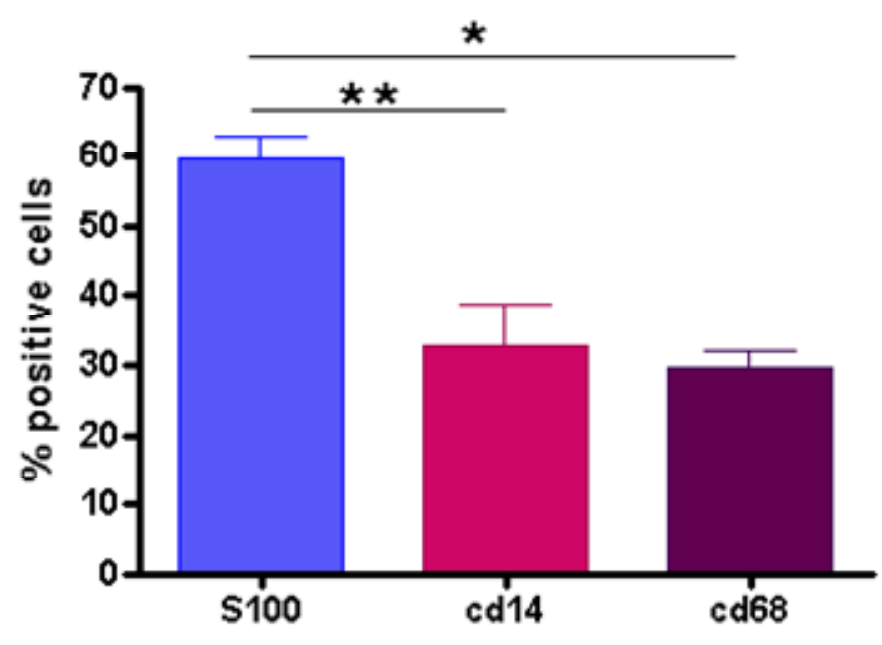

S100

CD14 CD64
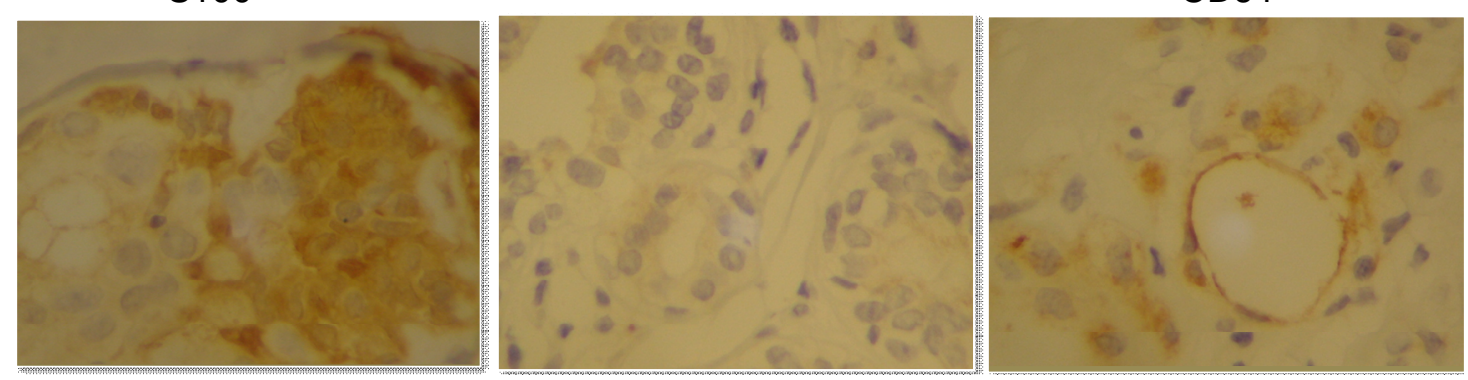

Figura 4- Imunohistoquímica da frequência de marcadores celulares de DCs e macrófafos presentes no tecido tumoral. As análises estatísticas foram realizadas pelo teste t não pareado; ${ }^{*}=p<0,01 ;{ }^{* *}=p<0,001$. 


\subsection{Comparação morfológica e fenotípica das células obtidas de voluntárias e de pacientes com cancer de mama antes e depois da cultura de diferenciação de PBMCs em DCs}

Para verificar as alterações morfológicas e fenotípicas induzidas pela cultura de geração de DCs a partir de PBMCs, foram analisadas caracterisitcas como tamanho, granulosidade e fenótipo usando os marcadores CD14, CD80, CD86, HLADR e CD11c através da citometria de fluxo nas células antes e depois da cultura.

Em voluntárias e em pacientes, foram observadas células grandes e granulosas consideradas DCs, recuperadas no sétimo dia da cultura, população esta que não foi identificada na análise de citometria feita com as PBMCs do iníco da cultura (Figura 5). Na análise fenotípica, a frequência de células expressando CD14 das voluntárias (antes: $46,1 \pm 6,8 \%$ e depois: $9 \pm 2,3 \%, p=0,001$ ) quanto das pacientes (antes: $51,6 \pm 7,3 \%$ e depois: $17,7 \pm 8,8 \%, p=0,03$ ) reduziu após a cultura de diferenciação. Por outro lado, os marcadores que caracterizam o fenótipo das DCs maduras apresentaram-se mais frequentes ao término da cultura em voluntárias (CD80 antes: $29,9 \pm 4,8 \%$ e depois: $64,3 \pm 7,3 \%, p=0,037$; CD86 antes: $32,2 \pm 11,3 \%$ e depois: $73,3 \pm 3,3 \%, p=0,004$; CD11c antes: $60,9 \pm 10,4 \%$ e depois: $86,3 \pm 2,6 \%$, $p=0,03$; HLA-DR antes: $70,8 \pm 5,5 \%$ e depois: $89,9 \pm 2,7 \%, p=0,009 ; n=7$ ) como em pacientes (CD80 antes: $17 \pm 7,7 \%$ e depois: 67,3 $\pm 7,1 \%, p=0,006$; CD86 antes: $54,4 \pm 6,2 \%$ e depois: $81,3 \pm 4,7 \%, p=0,0002$; CD11c antes: $69,3 \pm 6,8 \%$ e depois: $88 \pm 3,4 \%, p=0,003$; HLA-DR antes: $70,3 \pm 4,1 \%$ e depois: $85,8 \pm 3,5 \%, p=0,003 ; n=8$ ) (Figura 6). 

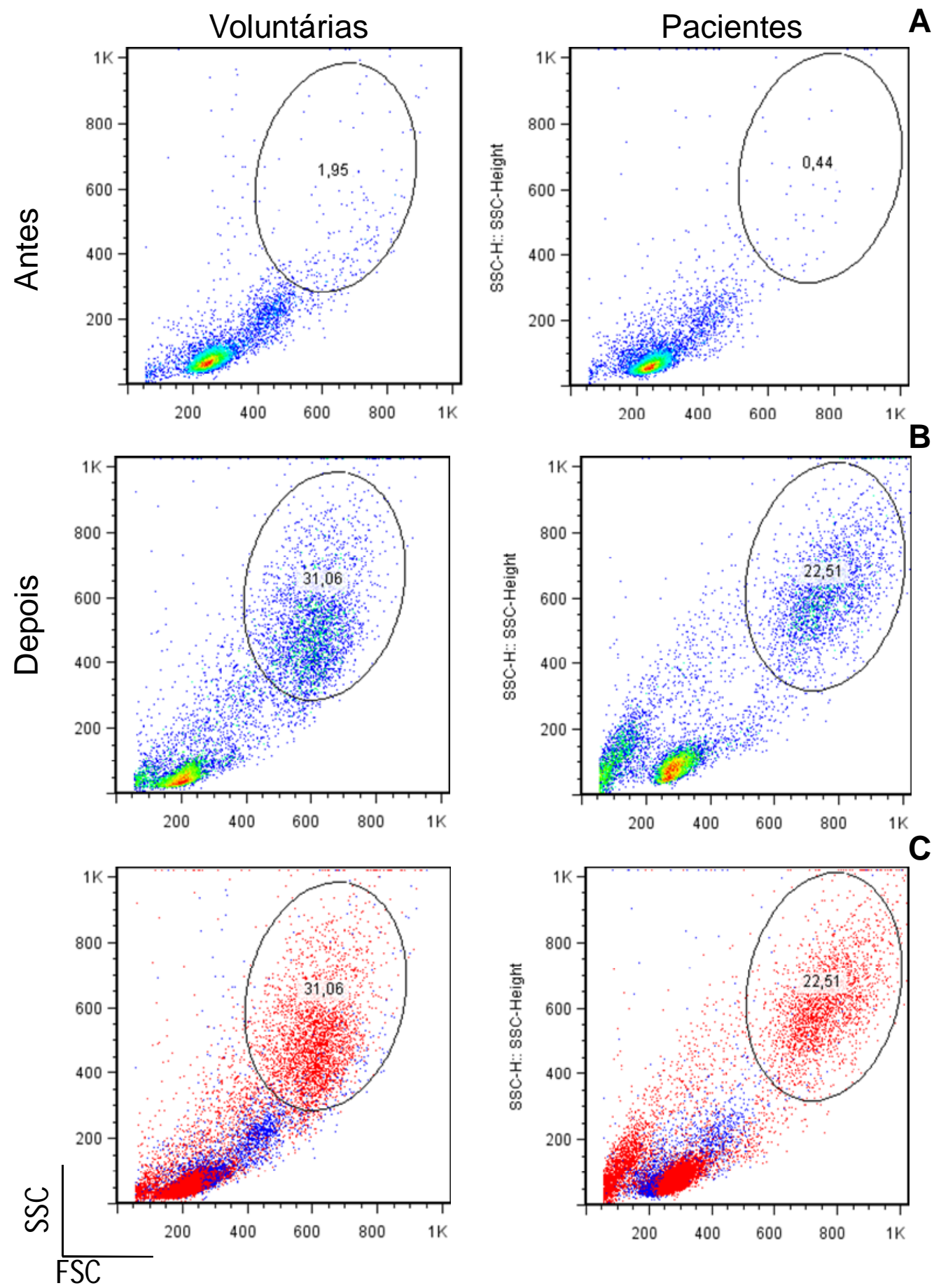

Figura 5- Gráficos representativos das populações de células por tamanho (FSC) e granulosidade (SSC) antes e depois da cultura de diferenciação em DCs. (A) As PBMCs obtidas por separação de gradiente de ficol a partir do sangue periférico de doadoras saudáveis e de pacientes com cancer de mama mostraram menor tamanho e pouca granulosidade. (B) Após a cultura de diferenciação, utilizando meio de cultura AIM$\checkmark$ suplementado com as citocinas IL-4, GM-CSF e TNF- $\alpha$, as células recuperadas apresentaram uma população maior e mais granulosa. (C) A sobreposição das células antes, representada em azul, e depois da cultura de diferenciação, representada em vermelho, revelou uma população grande e granulosa. 
Voluntárias

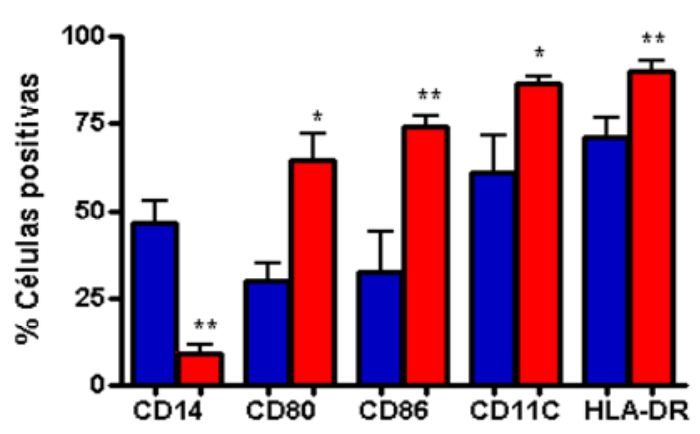

\section{Pacientes}

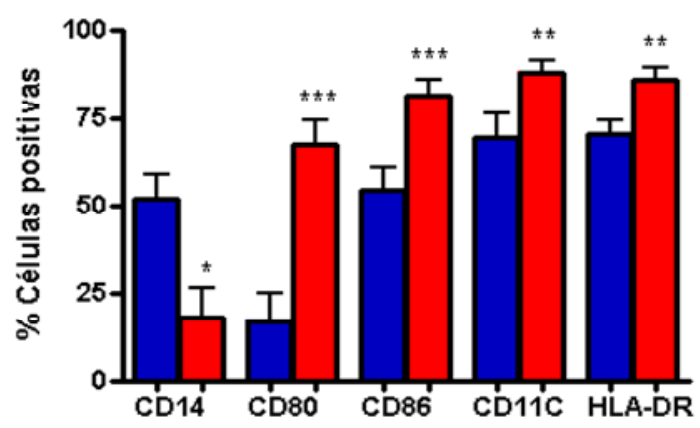

Células antes da cultura de diferenciação

Células depois da cultura de diferenciação

Figura 6- Freqüência de células expressando os marcadores celulares CD14, CD80, CD86, CD11c e HLA-DR, antes e depois da cultura de diferenciação suplementada com IL4, GM-CSF e TNF- $\alpha$. As análises estatisticas foram realizadas pelo teste t pareado; ${ }^{*} p<0,05 ;{ }^{* *} p<0,01 ;{ }^{* * *}=p<0,001$. 


\subsection{Comparação do rendimento da cultura de DCs a partir de PBMCs de voluntárias saudáveis e de pacientes com cancer de mama}

Partindo dos dados que mostraram que o protocolo de diferenciação de DCs a partir de PBMCs aplicado neste trabalho se mostrou eficiente, tanto em células voluntárias quanto em células de pacientes, foi feita uma análise quanto à freqüência das células recuperadas.

Considerando o número total de PBMCs plaqueadas $\left(2 \times 10^{6}\right.$ células), foi observado que o número de DCs recuperadas ao término da cultura, nas voluntárias, foi de $18,9 \%( \pm 2,6 n=18)$ e nas pacientes, de $11,7 \%( \pm 1 n=20)$ sendo esta uma redução significativa (Figura $7 A$ ). Em relação às PBMCs $\mathrm{CD}^{2} 4^{+}$, 0 rendimento, nas pacientes, foi de 9,5\% $( \pm 1,4 n=8)$, valor estatisticamente menor que o obtido nas voluntárias $19,6 \%( \pm 3,6 \mathrm{n}=8)$ (Figura 7B). Entretanto, os resultados mostraram que não houve diferenças, entre voluntárias saudáveis e pacientes com câncer de mama, na frequência de células recuperadas em relação ao número de células aderidas submetidas à cultura de diferenciação. Na análise morfológica, a frequência de células grandes e granulosas analisadas no "gate"de FSC e SSC, também não apresentou diferença entre os grupos.

Os resultados sugerem, portanto, que as PBMCs obtidas das pacientes são capazes de se diferenciar em DCs, mas com um rendimento menor. Este resultado parece ser um reflexo de um menor número de células aderidas das pacientes $(27,6 \% \pm 3,5 n=12)$ quando comparadas com as células das voluntárias saudáveis $(39,7 \% \pm 2,5 n=7)$ (Figura $7 C)$. 
A

B
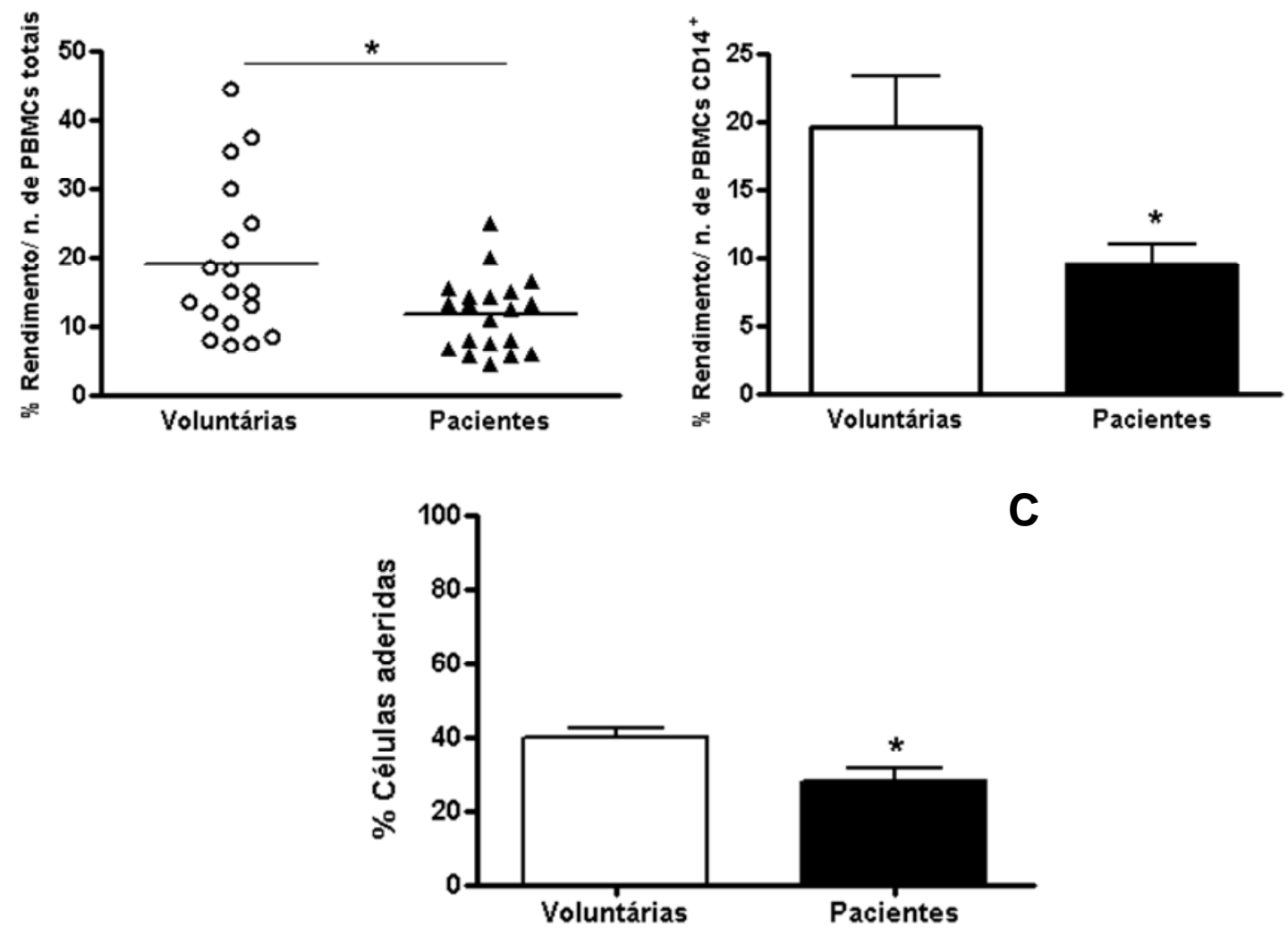

Figura 7- Rendimento relativo de cultura para diferenciação em DCs em voluntárias saudáveis e portadoras de câncer de mama. (A) Rendimento em relação ao número total de células semeadas inicialmente. (B) Rendimento em relação ao número de células CD14+ presentes na população inicialmente semeada. (C) Número de células aderidas em relação ao número de células semeadas. As análises estatisticas foram realizadas pelo teste t não-pareado e as diferenças assinaladas com *, tiveram $p<0,05$.

\subsection{Comparação fenotípica e funcional das DCs diferenciadas de PBMCs de voluntárias e de pacientes com cancer de mama}

Para determinar se as DCs derivadas de PBMCs de pacientes apresentavam as mesmas características fenotípicas que as DCs diferenciadas de PBMCs de voluntárias, foi realizada uma comparação da freqüência de células positivas para os marcadores celulares típicos de DCs, no "gate" definido a partir de uma população de células grandes e granulosas.

Os resultados desta comparação mostraram que entre as DCs das voluntárias houve maior freqüência de expressão de $\operatorname{HLA}$-DR $(92,2 \% \pm 1,7$ vs $83,2 \% \pm 3,2)$, 
CD11c $(91,5 \% \pm 1,4$ vs $82,1 \% \pm 4)$, CD86 (88\% \pm 2 vs $77,9 \% \pm 3,8)$, CD80 $(69,4 \% \pm$ $4,1$ vs $51,6 \% \pm 5,7)$ e CCR7 $(42 \% \pm 8,4$ vs $18,6 \% \pm 6,4)$. Já os marcadores CD1a, CD40 e CD83 não mostraram diferenças significativas (Figura 8).
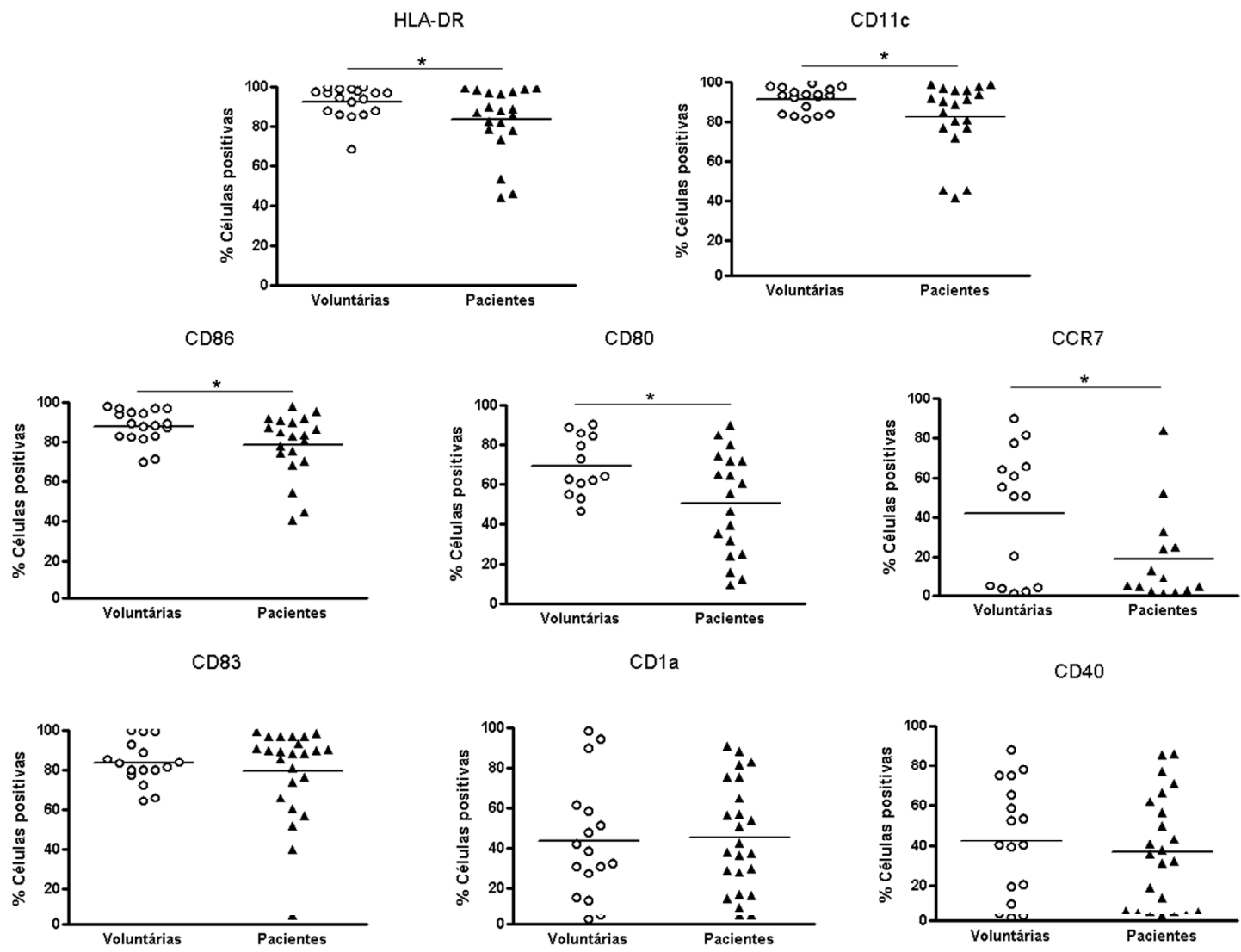

Figura 8- Comparação fenotípica entre DCs obtidas a partir de PBMCs de voluntárias saudáveis e de pacientes com câncer de mama. A análise estatística foi realizada pelo teste t não-pareado; as barras horizontais indicam diferenças com $p<0,05$.

Para verificar se as possíveis modificações fenotípicas poderiam influenciar a função das DCs de forma significativa, foi utilizado o ensaio de estimulação de linfócitos $\mathrm{T}$ alogenéicos (MLR), em co-cultura com DCs obtidas de PBMCs de voluntárias e de pacientes. Nas análises, inicialmente foi identificado por tamanho e granulosidade o "gate" definido como de linfócitos, tendo como referência uma amostra controle definida pela presença de linfócitos sem as DCs.

Após as co-culturas, observou-se um aumento claro no tamanho e granulosidade das células no "gate" de linfócitos, sugerindo a capacidade de estimulação linfocitária de DCs, tanto de voluntárias, quanto de pacientes (ilustrado 
na Figura 9A). Ainda nesta análise morfológica inicial, parece haver maior granulosidade nos linfócitos estimulados com DCs de voluntárias. Confirmando esta impressão, pode-se notar (ilustrado na Figura 9B), que linfócitos estimulados com DCs de voluntárias apresentam uma diluição claramente maior do corante CFSE, usado para detectar a divisão celular na população de linfócitos. Esta diluição pode ser usada para cálculo de um índice de proliferação, que analisado em todos os experimentos realizados (Figura 9D) confirma a menor capacidade de estimulação linfocitária por DCs das pacientes em comparação às de doadoras sadias $(1,2 \pm 0,07$ $n=20$ vs. $2,7 \pm 0,6 n=18)$.

Um fenômeno intrigante observado nestes ensaios foi o padrão distinto de estimulação de linfócitos T CD4 e CD8 pelas DCs de voluntárias e de pacientes. A figura 9C ilustra e a figura 9E resume o encontrado em todos os ensaios: DCs de pacientes têm atividade estimuladora sobre linfócitos CD8+ menor do que sua capacidade de estimular células CD4+. Como conseqüência disto, a relação CD4+/CD8+ cresce significativamente entre as células estimuladas com DCs de pacientes, quando em comparação com as células estimuladas com DCs de voluntárias sadias $(5,2 \pm 0,8 n=15$ vs. $2,1 \pm 0,3 n=14)$. Chama também a atenção, 0 aparecimento de uma subpopulação de células com baixa intensidade de marcação para CD8, entre os linfócitos estimulados com as DCs das pacientes. Este fenômeno foi observado em vários ensaios, mas não em todos, de modo que sua relevância não pôde ser estabelecida com segurança. 

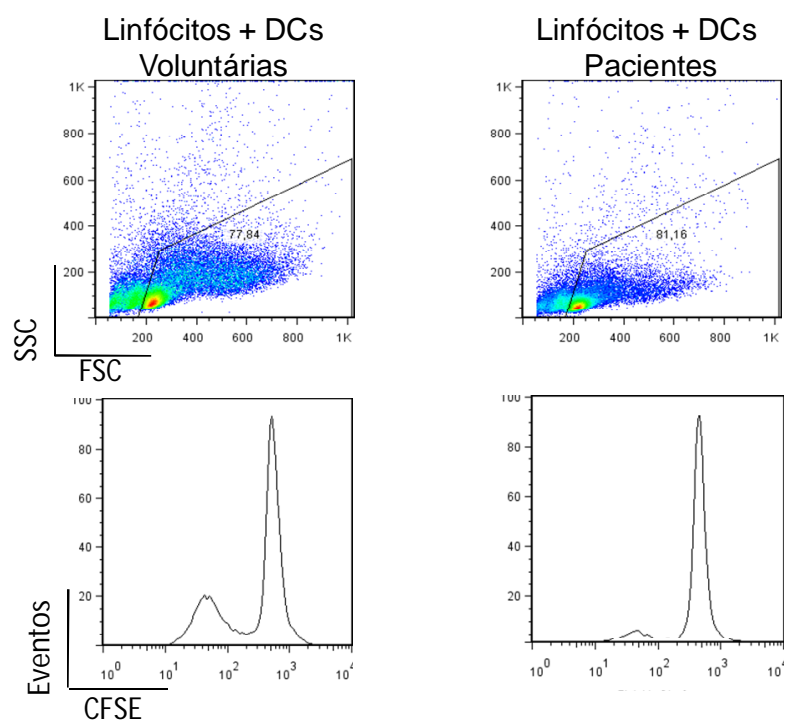

A
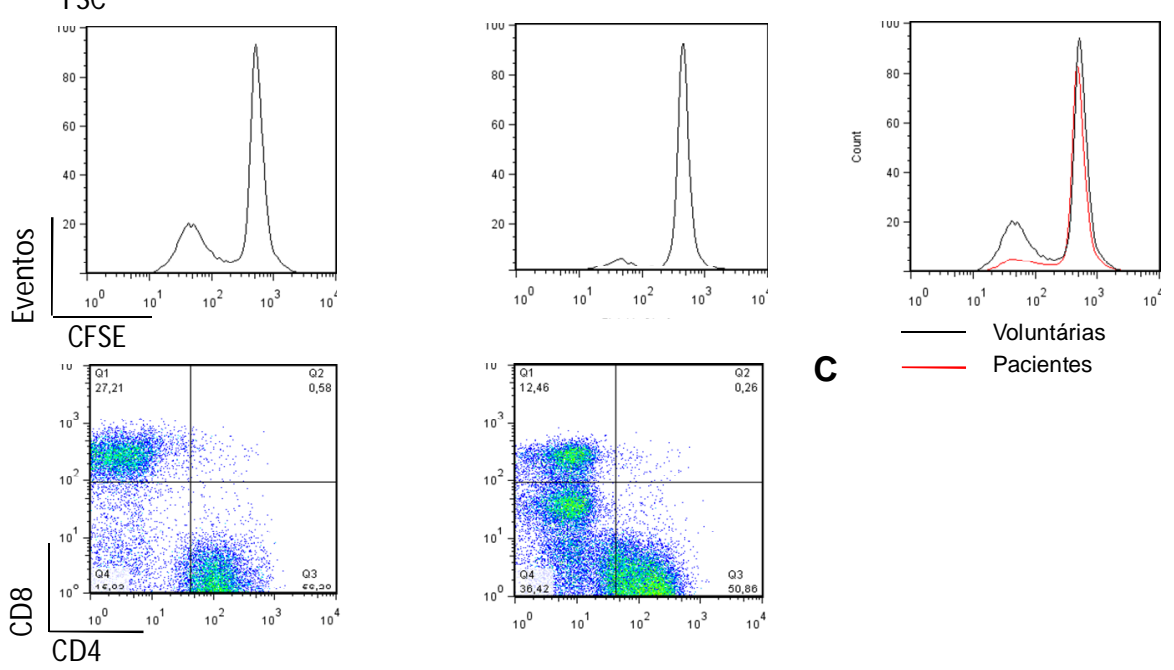

B

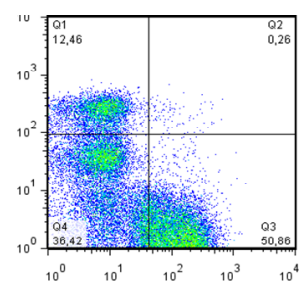

C Pacientes

D
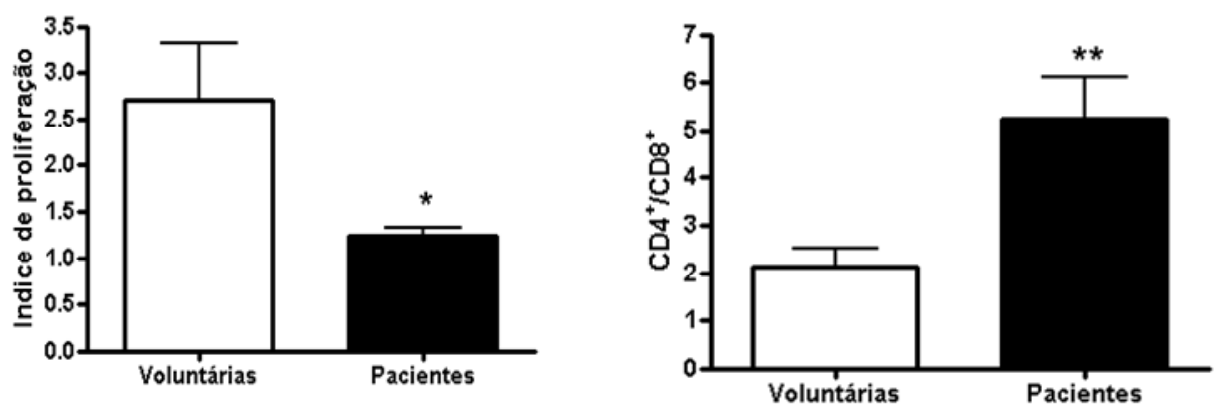

Figura 9- DCs diferenciadas de PBMCs de pacientes apresentam menor capacidade de induzir linfoproliferação que DCs diferenciadas a partir de PBMCs de voluntárias saudáveis.

(A) Gráficos ilustrando tamanho e granulosidade de linfócitos isolados e de linfócitos mantidos em co-cultura com DCs por cinco dias; (B) Histogramas ilustrando a diluição do CFSE em linfócitos isolados, linfócitos mantidos em co-cultura com DCs de voluntárias e de pacientes e a sobreposição dos histogramas dos linfócitos mantidos em co-cultura com DCs de voluntárias e de pacientes; (C) Gráficos ilustrando a distribuição de linfócitos quanto à marcação por CD4 e CD8 em células $\mathrm{CFSE}^{+}$, após co-cultura com DCs de voluntárias ou de pacientes; (D) Índice de proliferação linfocitária, calculado pelo coeficiente: MFI de linfócitos não-estimulados/MFI de linfócitos estimulados (MFI para a marcação com CFSE); (E) Relação entre as populações de células $\mathrm{CD}^{+} \mathrm{CFSE}^{+}$e $\mathrm{CD}^{+} \mathrm{CFSE}^{+}$após co-cultura com DCs de voluntárias ou de pacientes. As análises estatísticas foram realizadas pelo teste t não-pareado; ${ }^{\star} p=0,01,{ }^{\star \star} p=0,004$. 
Ao final das co-culturas, o sobrenadante das mesmas foi separado e utilizado para análise da presença das citocinas, IFN- $\gamma$ e IL-10 (Figura 10). Os resultados mostraram as co-culturas de linfócitos com DCs de voluntárias apresentaram uma concentração de IFN- $\gamma$ significativamente maior que a concentração encontrada no sobrenadante das co-culturas de linfócitos e DCs de pacientes $(534,7 \mathrm{ng} / \mathrm{mL} \pm$ $156,92,7 \mathrm{n}=18$ vs. $238,9 \mathrm{ng} / \mathrm{mL} \pm 15,5, \mathrm{n}=20)$. Em contraste, na análise da concentração de IL-10 foi observado o oposto, com concentração significativamente menor nas culturas com células de voluntárias $(57,4 \mathrm{pg} / \mathrm{mL} \pm 19,2, \mathrm{n}=18$ vs. 213,7 $\mathrm{pg} / \mathrm{mL} \pm 51,5, \mathrm{n}=20)$.
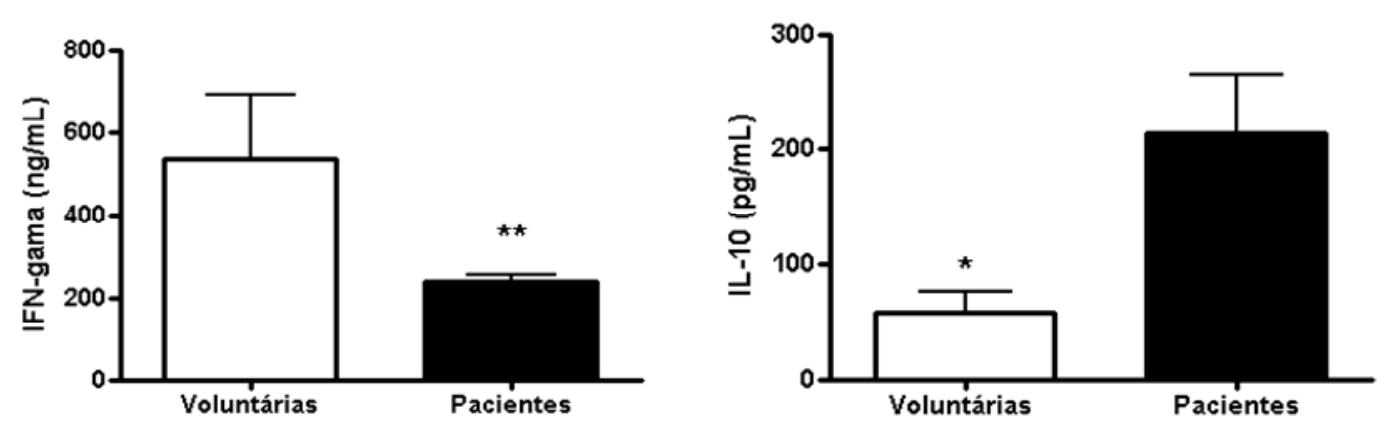

Figura 10- Concentração de IFN- $\gamma$ e IL-10 no sobrenadante da co-cultura de linfócitos alogenéicos com DCs obtidas de PBMCs de voluntárias e de pacientes. As análises estatísticas foram realizadas pelo teste t não-pareado; ${ }^{*}=p=0,01 ;{ }^{* *}=p=0,001$. 


\subsection{Expressão de receptores para IL-4 e GM-CSF em monócitos obtidos do sangue periférico de voluntárias saudáveis e de pacientes com câncer de mama}

Considerando que as DCs diferenciadas de PBMCs de pacientes mostraram menor expressão de HLA-DR, CD11c, CD80, CD86 e CCR-7, redução na capacidade de induzir linfoproliferação e um padrão "imunossupressor" de indução de produção de citocinas nas reações alogenêicas, quando comparadas com as DCs obtidas de PBMCs de voluntárias saudáveis, investigamos a possibilidade de haver uma diferença nos monócitos das pacientes em relação aos das voluntárias sadias. Assim, foi feita a análise dos receptores para as citocinas GM-CSF (CD116) e IL-4 (CD124), que são usadas na cultura de diferenciação.

As PBMCs de voluntárias e pacientes foram selecionadas quanto à expressão de $\mathrm{CD}_{14}^{+}$e nesta população foi avaliada a freqüência de células positivas para CD116 e CD124. Não houve diferença na frequência de células CD14 ${ }^{+}$CD116 ${ }^{+}$entre voluntárias e pacientes, entretanto a população de PBMCs CD14 ${ }^{+}$CD124 $4^{+}$foi menor nas pacientes $(9,6 \pm 3,8 n=7)$ quando comparada com as voluntárias $(32,6 \pm 3,6$ $n=7)$ (Figura 11A).

A intensidade de expressão dos receptores na população positiva se distingue entre as células de doadoras sadias e de pacientes. Neste caso, tanto os receptores para GM-CSF quanto para IL-4 exibiram menor expressão nos monócitos de pacientes (CD116: $172,4 \pm 32,6$ vs. $250,3 \pm 14,5 n=11$; CD124: $34,95 \pm 5,1$ vs. 55,9 $\pm 6,5 \mathrm{n}=11$ ) (Figura 11B). A figura 11C ilustra estes achados em gráficos onde a marcação de células de voluntárias aparece em preto, e a das pacientes, em vermelho. 


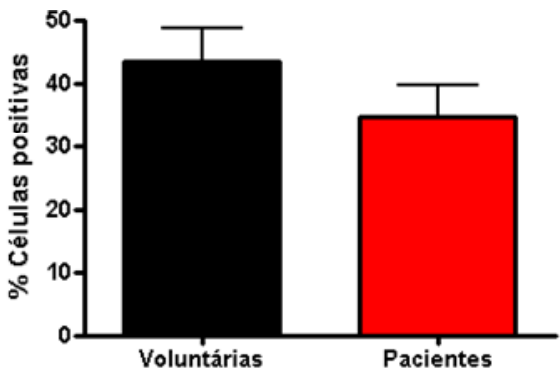

$\mathrm{CD}_{116^{+}}$
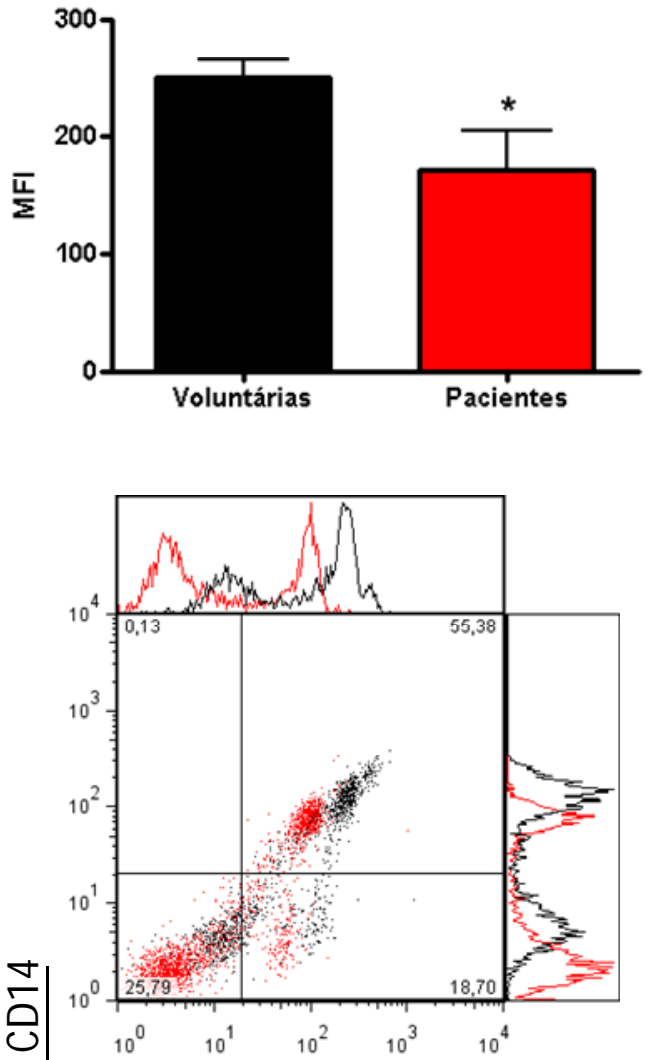

CD116

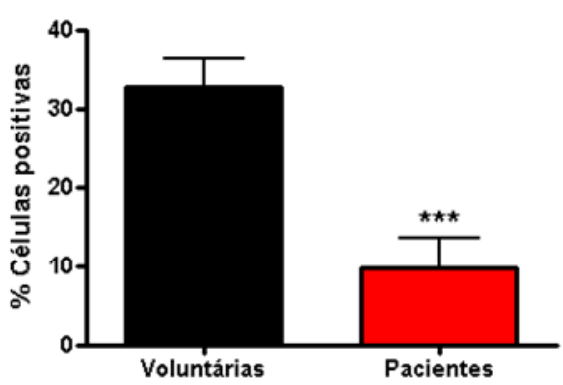

CD124

B

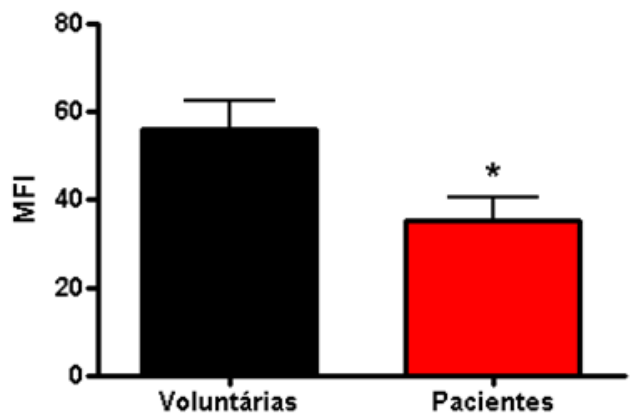

C

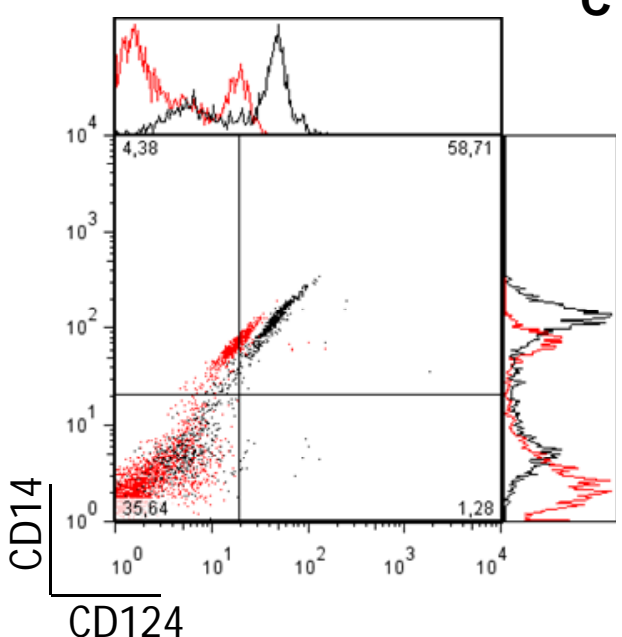

Figura 11- Expressão dos receptores para citocinas GM-CSF (CD116) e IL4 (CD124) em PBMCs $\mathrm{CD}_{14}{ }^{+}$de voluntárias e de pacientes. (A) Frequência de células duplo positivas $\mathrm{CD}_{14}{ }^{+} \mathrm{CD} 116^{+}$, e CD14 ${ }^{+} \mathrm{CD} 124^{+}$; (B) Intensidade de marcação para CD116 e CD124 na população positiva; (C) Os gráficos de sobreposição ilustram as diferenças entre a frequência e o MFI das PBMCs $\mathrm{CD}_{14}{ }^{+} \mathrm{CD} 116^{+}$e $\mathrm{CD} 14^{+} \mathrm{CD} 124^{+}$entre voluntárias, representadas em preto $e$ as pacientes representadas em vermelho. As análises estatísticas foram realizadas pelo teste t não-pareado, ${ }^{* *}=p=0,0009,{ }^{*}=p<0,05$. 


\subsection{Efeito da presença das células tumorais ou seus fatores solúveis na ativação de DCs a partir de PBMCs obtidas de voluntárias saudáveis e pacientes com câncer de mama}

Observamos que DCs diferenciadas de PBMCs de pacientes com câncer de mama apresentam alterações fenotípicas e funcionais, algumas delas desde seus precursores, os monócitos. Nesta etapa resolvemos investigar o efeito da presença de possíveis fatores solúveis secretados por células de duas linhagens tumorais de mama, uma, estrógeno-dependente (MCF-7) e outra, estrógenoindependente (SK-BR-3) sobre a ativação de DCs diferenciadas in vitro. Para isso, células de tumor irradiadas foram usadas para co-cultura direta e células de tumor viáveis foram usadas para co-cultura em transwell, adicionadas no quinto dia do protocolo de diferenciação de monócitos em DCs. No mesmo dia, as culturas foram suplementadas com TNF- $\alpha$. No sétimo dia, ao término da cultura, as células foram analisadas quando ao fenótipo, a capacidade de induzir proliferação em linfócitos alogenéicos e o padrão de produção de citocinas.

Os resultados mostraram que, nas voluntárias, a presença das células irradiadas de linhagem tumoral não modificou a frequência dos marcadores de DCs quando comparados com o controle, obtido da cultura de DCs sem tumor. Nas pacientes, porém, o tratamento com a linhagem tumoral SK-BR-3 provocou a diminuição significativa na frequência de células CD11c ${ }^{+}$(Figura 12). 


\section{CD11c}

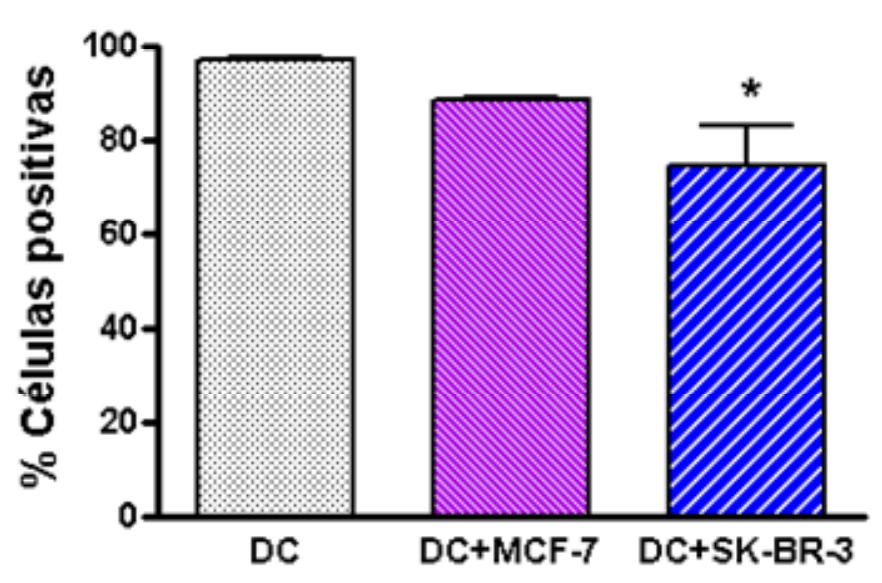

Figura 12- Efeito da co-cultura de DCs com linhagens tumorais de MCF-7 e SK-BR-3 sobre o fenótipo. As células de tumor irradiadas foram adicionadas ao quinto dia da cultura das DCs derivadas de PBMCs de pacientes ao mesmo tempo em que as culturas foram suplementadas com TNF- $\alpha$. A análise estatística foi realizada pelo teste ANOVA com pós-teste de Bonferroni; ${ }^{*}=p<0,05$.

No ensaio de MLR as DCs derivadas de PBMCs de voluntárias cultivadas na presença de células tumorais provocaram proliferação com tendência a diminuição em relação ao controle, mas sem diferença significativa (Figura 13A), enquanto para as DCs derivadas de pacientes os resultados não mostraram diferenças. Na dosagem de IFN- $\gamma$ e IL10 no sobrenadante da cultura de linfoproliferação, não foram observadas alterações significativas quando as DCs foram derivadas de pacientes, entretanto nas co-culturas onde as células estimuladoras foram as DCs de voluntárias expostas à SK-BR-3 foi observado um aumento na concentração de IL10 (Figura13B). 

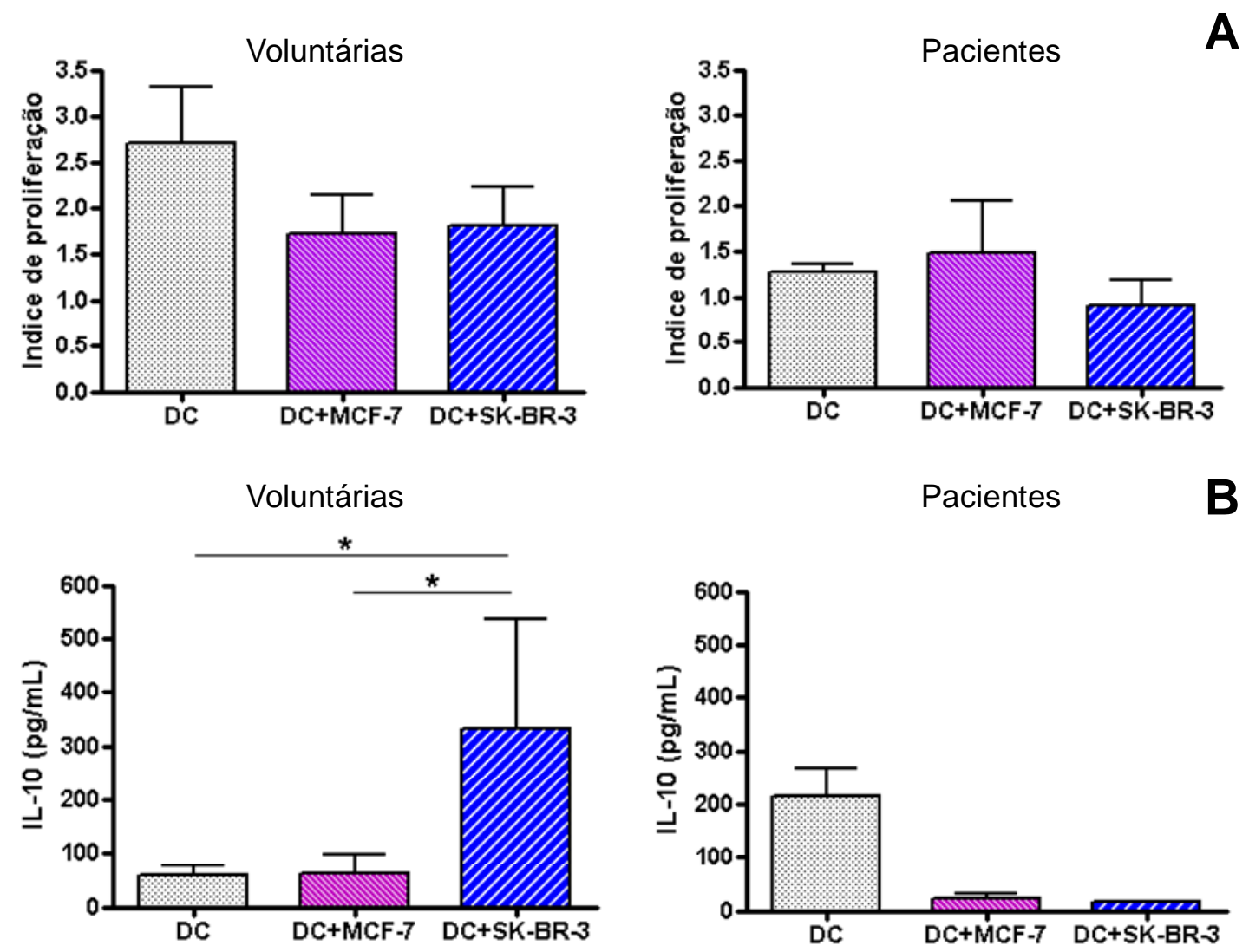

Figura 13- Efeito da co-cultura de DCs com linhagens tumorais de MCF-7 e SK-BR-3 sobre a capacidade de induzir linfoproliferação e produção de citocinas. As células de tumor irradiadas foram adicionadas ao quinto dia da cultura das DCs derivadas de PBMCs voluntárias e suplementada com TNF- $\alpha$ para a indução da maturação das DCs. As análises estatisticas foram realizadas pelo teste ANOVA e pós-teste de Bonferroni; * $=$ $\mathrm{p}<0,05$

Nos experimentos feitos com placa de cultura transwell, as células tumorais foram mantidas em co-cultura com as DCs compartilhando do mesmo meio, mas sem contato direto entre as células. Desta forma, características funcionais e fenotípicas de DC maduras foram avaliadas em presença de fatores solúveis possivelmente secretados pelo tumor. Os resultados mostraram que o fenótipo das DCs não se alterou com a presença de fatores solúveis tumorais. No ensaio de MRL também não houve diferença no índice de proliferação de linfócitos mantidos em cocultura com DCs de voluntárias e de pacientes, entretanto o coeficiente de linfócitos $\mathrm{CD}^{+}$em relação aos linfócitos $\mathrm{CD}^{+}$aumentou nas DCs de voluntárias mantidas em 
co-cultura com fatores solúveis produzidos pelas células tumorais quando comparado com controle (Figura 14A), e em presença das células da linhagem SKBR-3 foi observado um aumento significativo da concentração de IL10 no sobrenadante da cultura de linfoproliferação (Figura 14B).
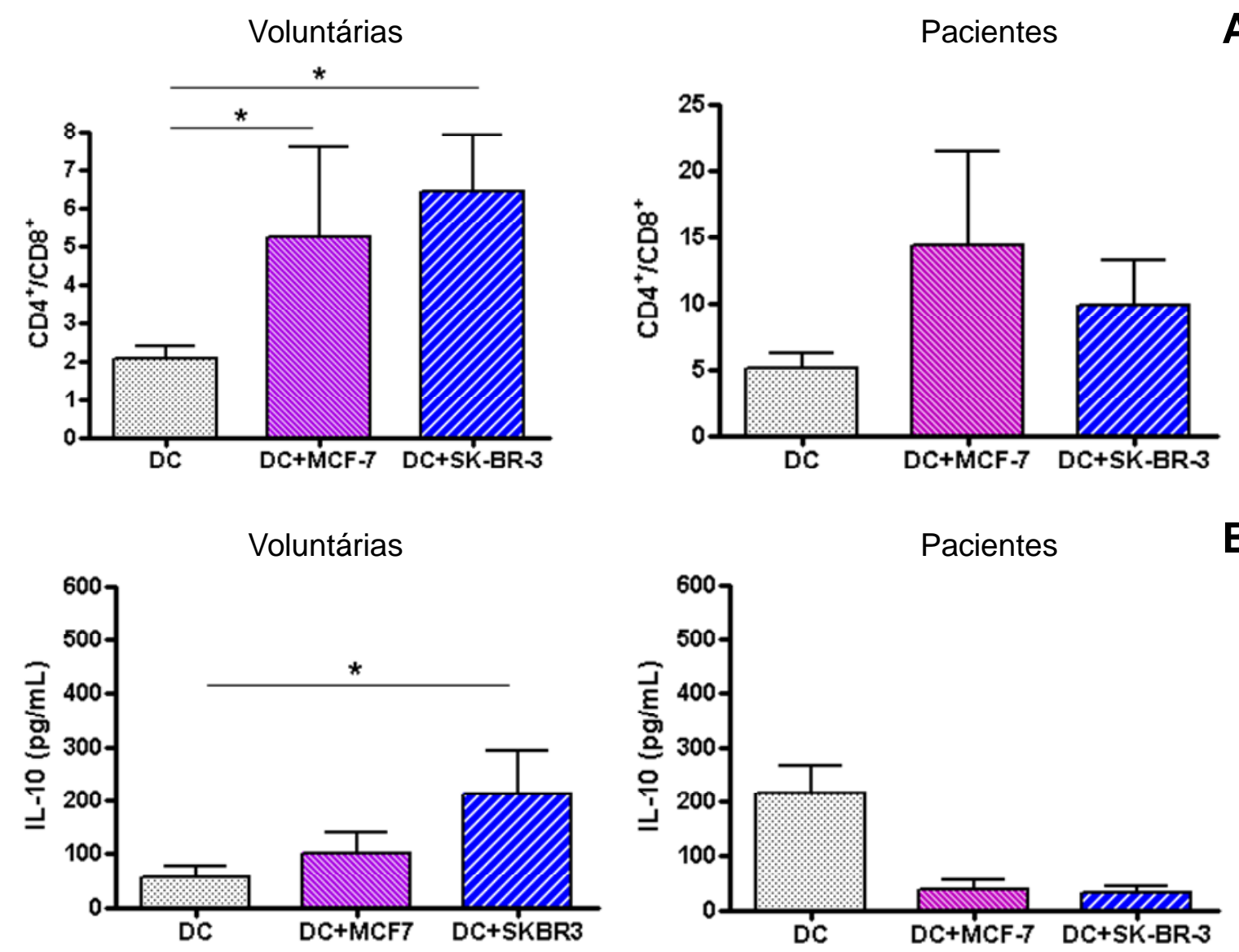

Figura 14- Efeito de fatores solúveis derivados das linhagens tumorais, MCF-7 e SK-BR-3, sobre fenótipo e função de DCs derivadas de doadoras saudáveis. As células de tumor viáveis foram adicionadas no quinto dia, por transwell, na cultura das DCs derivadas de PBMCs de voluntárias, suplementadas com TNF- $\alpha$ no mesmo dia. As análises estatísticas foram realizadas pelo teste ANOVA one-way e pós-teste de Bonferroni; * $=$ $\mathrm{p}<0,05$. 


\subsection{Efeito do pH baixo induzido pelo ácido láctico na diferenciação de DCs a partir de PBMCs de voluntárias e de pacientes}

A presença de fatores solúveis produzidos pelas células tumorais modifica as condições normais, como, por exemplo, a presença do ácido lático que altera o pH e que também já foi descrito como capaz de alterar a capacidade de geração de DCs maduras a partir de PBMCs. No presente trabalho foi investigado o efeito do $\mathrm{pH}$ sobre o fenótipo, a capacidade de induzir linfoproliferação e produção de citocinas de DCs diferenciadas de PBMCs de voluntárias e de pacientes com câncer de mama.

Na figura 15, os resultados mostraram que o tratamento com ácido lático não modificou a expressão de HLA-DR e CD11c nas DCs obtidas da cultura de diferenciação a partir de PBMCs de voluntárias, mas nas pacientes foi observada

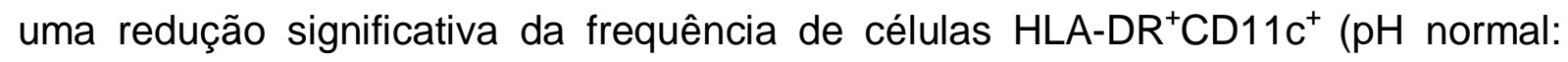
91,2 $\pm 1,3 ; \mathrm{pH}$ ácido: $69,1 \pm 7,5)$.
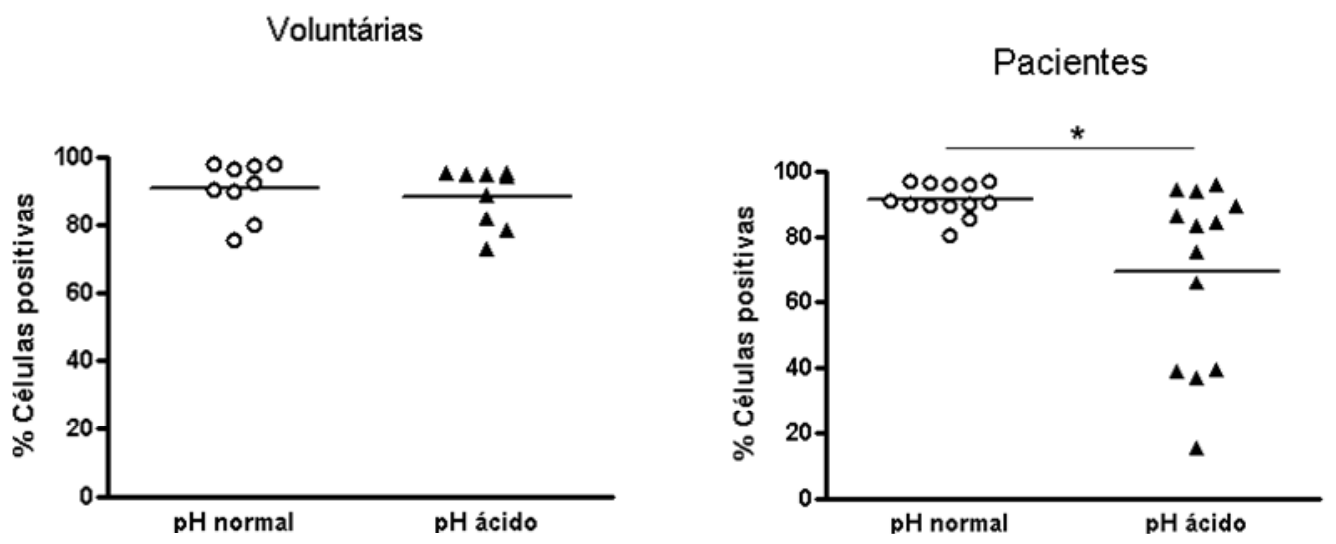

Figura 15- Efeito do ácido lático no fenótipo de DCs derivadas de PBMCs de voluntárias e de pacientes com câncer mamário. As análises estatísticas foram realizadas pelo teste $t$ pareado; * $p<0,05$. 
No ensaio funcional de MLR, as DCs de voluntárias provocaram um índice de proliferação menor expostas ao $\mathrm{pH}$ ácido, quando comparado com as células não tratadas, mas o resultado não foi estatisticamente diferente. Nas pacientes o índice de proliferação não se alterou com o a acidificação da cultura em presença do ácido lático; os valores dos índices de proliferação, nas pacientes, se mantiveram baixos, independentemente do tratamento. As diferenças observadas foram entre os índices obtidos de co-cultura de linfócitos com DCs de voluntárias e DCs de pacientes $(2,7 \pm 0,6 n=18$ vs $1,2 \pm 0,07 n=20)$, já descritas, e que se mantiveram com DCs de pacientes tratadas com lactato $(2,7 \pm 0,6 n=18$ vs $1,3 \pm 0,1 n=13)$ (Figura 16A). A relação de linfócitos $\mathrm{CD}^{+}$e $\mathrm{CD} 8^{+}$nas co-culturas com DCs não sofreu alteração pelo tratamento com o ácido lático, tanto nas DCs derivadas de PBMCs de voluntárias quanto de pacientes, mantendo-se apenas a diferença entre voluntárias e pacientes, já mostrada em resultados anteriores (Figura 16B). O tratamento com ácido lático reduziu a concentração de IFN- $\gamma$ no sobrenadante da cocultura de linfócitos e DCs, sendo que nas voluntárias, esta diminuição não foi estatisticamente significativa, mas o foi nas pacientes $(\mathrm{pH}$ normal: $238,9 \mathrm{ng} / \mathrm{mL} \pm$ 15,5, $\mathrm{n}=20$ vs. $\mathrm{pH}$ ácido: $171 \mathrm{ng} / \mathrm{mL} \pm 20,1, \mathrm{n}=13$ ) (Figura $16 \mathrm{C}$ ). Na figura $16 \mathrm{D}$, a concentração de IL-10 não sofreu alterações significativas nas DCs de voluntárias tratadas com ácido lático, mas nas pacientes o tratamento com ácido lático reduziu significativamente a concentração de IL-10 ( $\mathrm{pH}$ normal: $213,7 \pm 51,1 \mathrm{n}=20$ vs. $\mathrm{pH}$ ácido: $5,8 \pm 1,1 \mathrm{n}=13$ ). Entre voluntárias e pacientes, a produção elevada de IL10, já descrita para cultura de DCs de pacientes em $\mathrm{pH}$ normal, reduziu drasticamente com o tratamento em meio ácido, ficando com valores abaixo dos encontrados para DCs de voluntárias em pH normal $(5,8 \pm 1,1 \mathrm{n}=13$ vs $57,4 \pm 19,2 \mathrm{n}=18)$ e em $\mathrm{pH}$ ácido $(5,8 \pm 1,1 \quad n=13$ vs $79,3 \pm 36,1 n=8)$. 
A
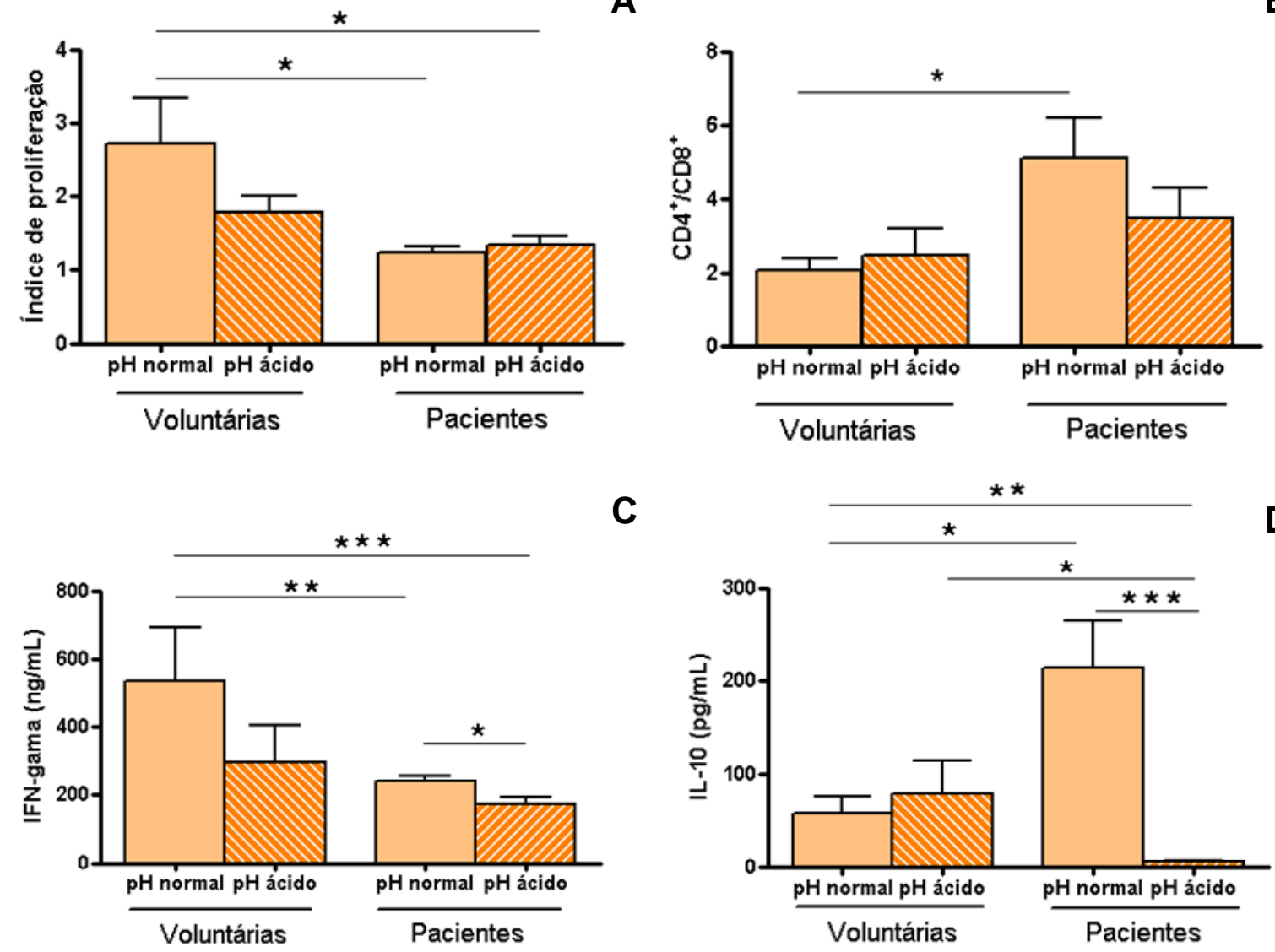

C

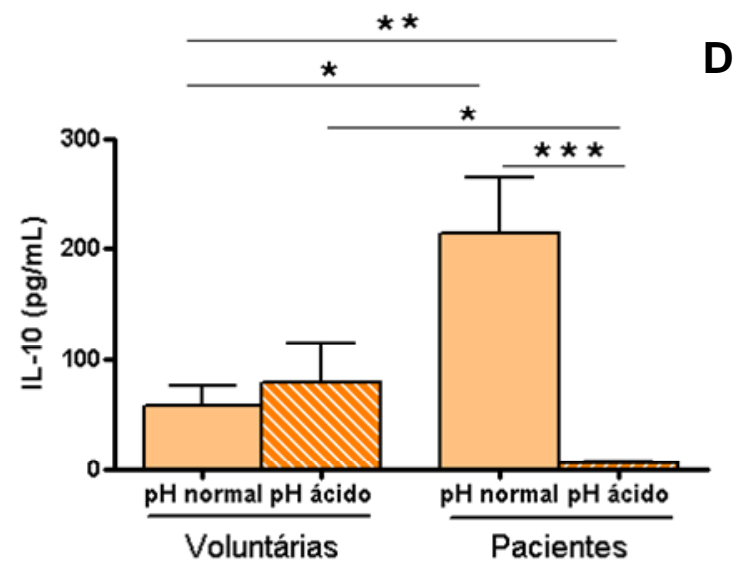

Figura 16- Efeito do ácido lático na função de DCs derivadas de PBMCs de voluntárias e de pacientes com câncer mamário. (A) Índices de proliferação induzidos pelas diferentes DCs sobre linfócitos alogenêicos; (B) Relação entre linfócitos $\mathrm{CD}^{+}$e $\mathrm{CD} 8^{+}$, marcados com CFSE, e respondendo ao estímulo com as DCs; (C) Concentração de IFN- $\gamma$ no sobrenadante da MLR com as diferentes DCs; (D) Concentração de IL-10 no sobrenadante da MLR com as diferentes DCs. As análises estatísticas foram realizadas pelo teste t não-pareado, ${ }^{* * *}=p=0,0005,{ }^{* *}=p<0,005,{ }^{*}=p<0,05$. 


\subsection{Participação da via p38MAPK nas alterações fenotípicas e funcionais induzidas pelo ácido lático na cultura de diferenciação de PBMCs em DCs de voluntárias e de pacientes}

Nas DCs obtidas de PBMCs de voluntárias saudáveis, os resultados mostraram que o tratamento com o inibidor da p38MAPK reduziu a frequência de células $\mathrm{HLA}-\mathrm{DR}{ }^{+} \mathrm{CD} 11 \mathrm{c}^{+}$, independente do tratamento com o lactato. Os resultados mostraram que nas voluntárias a frequência de células duplo positivas era de 90,7\% $( \pm 2,7 \mathrm{n}=9)$ em pH normal, sem SB203580. O efeito do inibidor da via de sinalização mediada pela p38MAPK reduziu a frequência de células $\mathrm{HLA}_{-}-\mathrm{R}^{+} \mathrm{CD} 11 \mathrm{c}^{+}$para $71,7 \%( \pm 2,1 \mathrm{n}=8)$ em $\mathrm{pH}$ normal e 77,6\% ( $\pm 3,2 \mathrm{n}=8)$ em $\mathrm{pH}$ ácido. Nas pacientes foi observada a redução da frequência de células $\mathrm{HLA}-\mathrm{DR}^{+} \mathrm{CD} 11 \mathrm{c}^{+}$em meio acidificado (pH normal: 88,6 \pm 1,9 $\mathrm{n}=11$; $\mathrm{pH}$ ácido: 69,1 \pm 7,5 $\mathrm{n}=13$ ) independentemente do tratamento com o inibidor (Figura 17A).

No ensaio funcional de MRL foi observado que não houve diferença estatística nos índices de proliferação induzidos por DCs obtidas a partir de PBMCs diferenciadas em meio com $\mathrm{pH}$ normal ou $\mathrm{pH}$ ácido, com ou sem o tratamento com o inibidor da p38MAPK (Figura 17B). Entretanto nas células de voluntárias os resultados mostraram uma tendência a redução do índice de proliferação e um aumento da relação de linfócitos $\mathrm{CD}^{+}$para $\mathrm{CD}^{+}$quanto em presença do inibidor (Figura 17C). Na determinação de citocinas no sobrenadante da MRL, os resultados mostraram a concentração de IFN- $\gamma$ nas DCs obtidas de PBMCs de voluntárias, mantidas em cultura com o pH normal sem o SB 203580 foi $534,7 \mathrm{ng} / \mathrm{mL}( \pm 156,9$ $\mathrm{n}=6$ ), entretanto, a inibição da via de sinalização mediada pela p38MAPK reduziu a concentração de IFN- $\gamma$ tanto em pH normal $(28,9 \pm 8 n=6)$, como em pH ácido (126,9 
$\pm 55,5 \mathrm{n}=8$ ). Nas pacientes, a produção de IFN- $\gamma$ foi menor em todos os tratamentos quando comparados com o controle, em pH ácido sem SB $203580(171 \pm 20,1 \mathrm{n}=13$ vs $238,9 \pm 15,5 \mathrm{n}=11)$, bem como na presença do inibidor, em $\mathrm{pH}$ normal $(164,1 \pm$ 9,7 $\mathrm{n}=8$ vs $238,9 \pm 15,5 \mathrm{n}=11)$ e em pH ácido $(162,9 \pm 19,3 \mathrm{n}=10$ vs $238,9 \pm 15,5$ $\mathrm{n}=11$ ) (Figura 18A). Na dosagem de IL10, as culturas de DCs voluntárias não apresentaram alterações entre os tratamentos, e nas pacientes a redução desta citocina ocorreu em meio ácido sem inibidor $(5,8 \pm 1,1 \mathrm{n}=13)$ e na presença do inibidor em pH normal $(8,6 \pm 1,8 \mathrm{n}=8)$ e em pH ácido $(10,8 \pm 2,4 \mathrm{n}=10)$ em relação ao controle $(213,7 \pm 51,5 n=11)$ (Figura 18B). 


\section{Voluntárias}
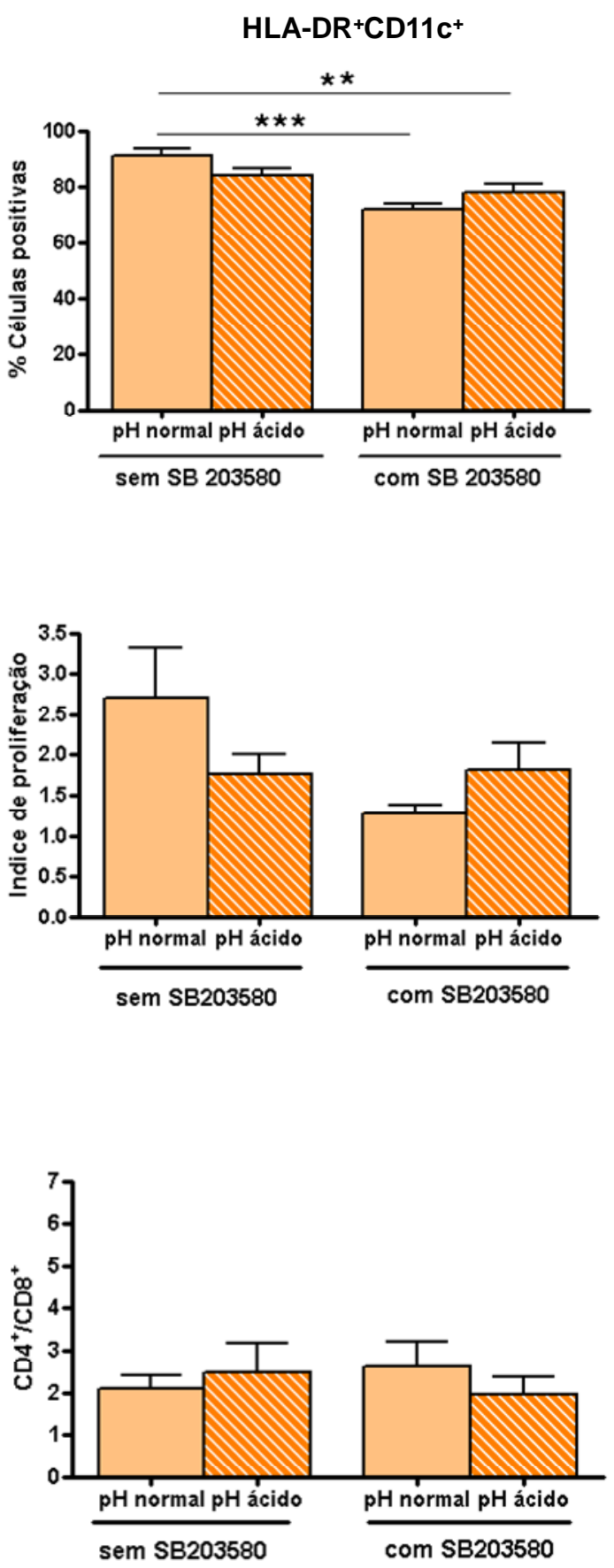

\section{Pacientes}

HLA-DR+CD11c ${ }^{+}$

A

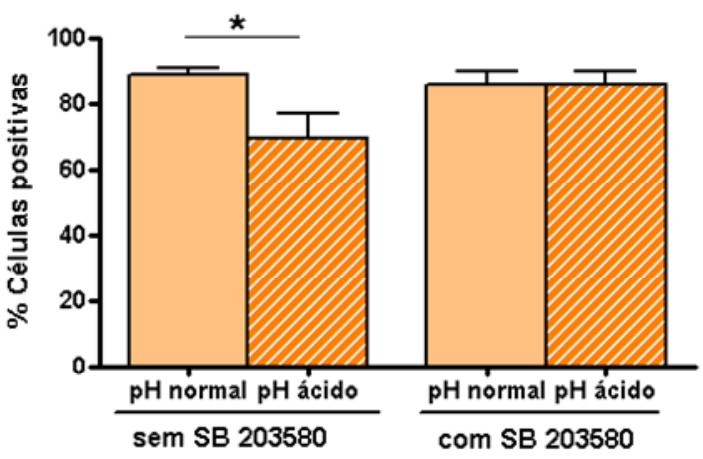

B

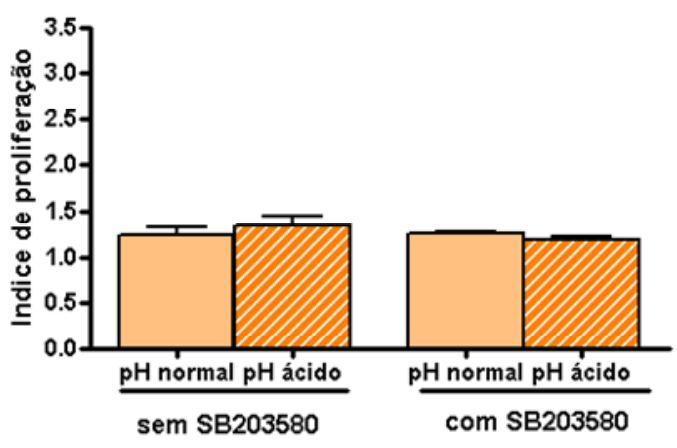

C

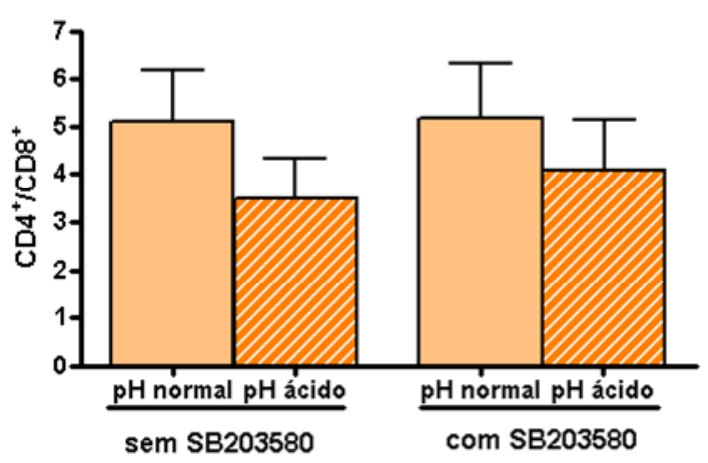

Figura 17- Efeito da p38MAPK no fenótipo e na função de DCs derivadas de PBMCs de voluntárias e de pacientes com cancer de mama diferenciadas em pH normal e pH ácido. (A) Nas DCs diferenciadas de PBMCs de voluntárias a inibição da p38MAPK reduziu a frequência de células $\mathrm{HLA}-\mathrm{DR}^{+} \mathrm{CD} 11 \mathrm{c}^{+}$, independente do $\mathrm{pH}$; $(\mathrm{B}) \mathrm{O}$ tratamento com inibidor da p38MAPK não alterou de forma significativa os valores do índice de proliferação; (C) O coeficiente entre as populações de linfócito $\mathrm{CD}^{+}$e $\mathrm{CD}^{+}$não se alterou de forma significativa. As análises estatísticas foram realizadas pelo teste $t$ não pareado; ${ }^{*}=p<0,05 ;{ }^{* *}=p<0,001 ;{ }^{* * *}=p<0,0001$. 

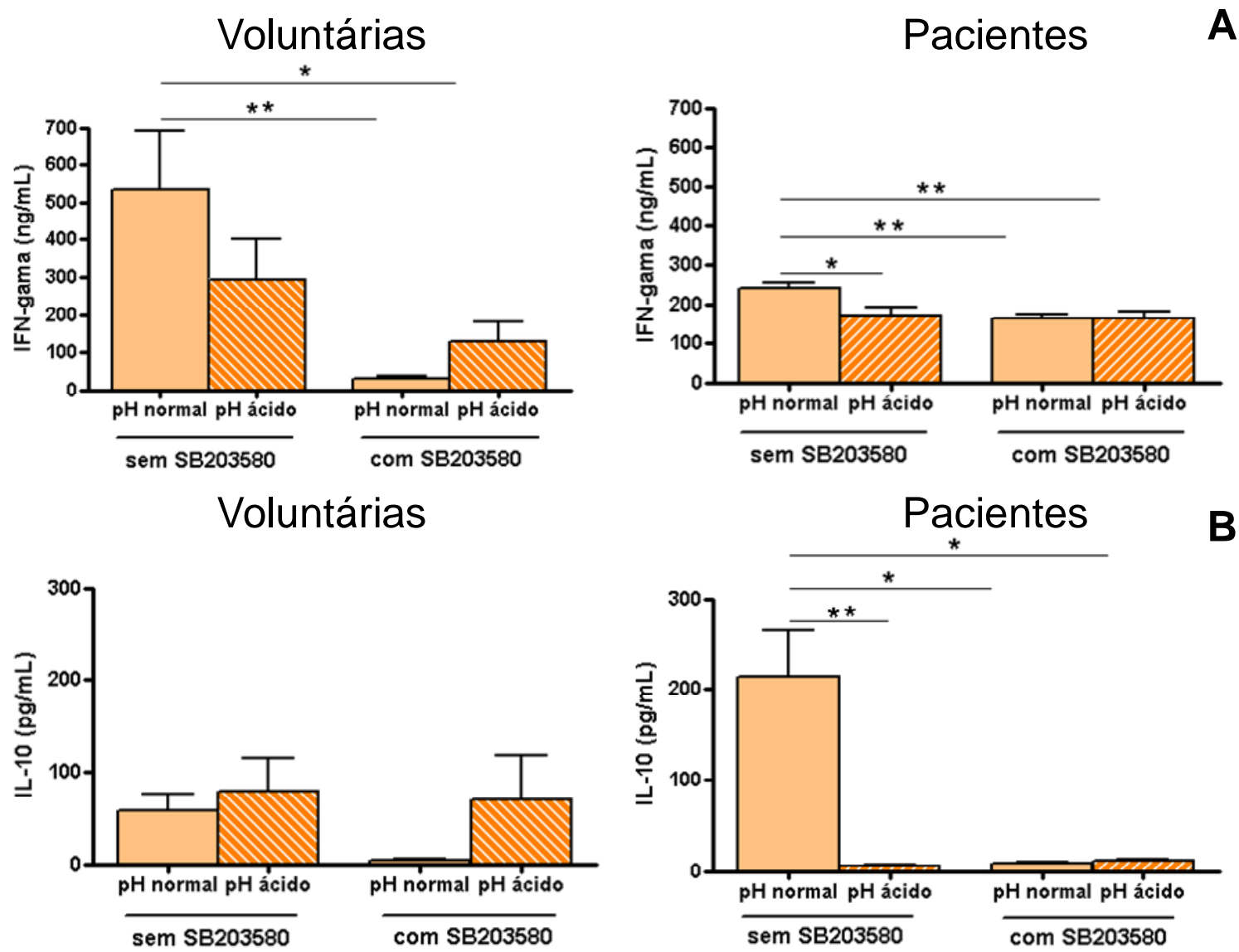

Figura 18- Efeito da p38MAPK na produção de citocinas no sobrenadante de MRL de DCs derivadas de PBMCs de voluntárias e de pacientes com cancer de mama mantidas em pH normal ou pH ácido. (A) Redução na concentração de IFN- $\gamma$ pela inibição da via p38MAPK nas DCs de voluntárias, independente ao $\mathrm{pH}$, e nas pacientes em todos tratamentos. (B) A concentração de $\mathrm{IL}-10$, nas voluntárias, não apresentou alteração, entretanto nas pacientes foi observada uma redução em todos os grupos tratados. As análises estatísticas foram realizadas pelo teste t não pareado; ${ }^{*}=p<0,05 ;{ }^{* *}=p<0,001$. 


\subsection{Expressão de HSP27 em DCs diferenciadas de PBMCs de voluntárias e de pacientes}

Os resultados mostraram que as pacientes apresentam uma expressão maior de HSP27, que se reduziu com o tratamento feito em meio ácido e/ou com inibidor da p38MAPK. Nas voluntárias, não foi observada diferenças significativas na expressão do mRNA para HSP27 (Figura 19). Destacamos que em todas as condições, a expressão de mRNA para HSP27 foi maior nas células das pacientes.
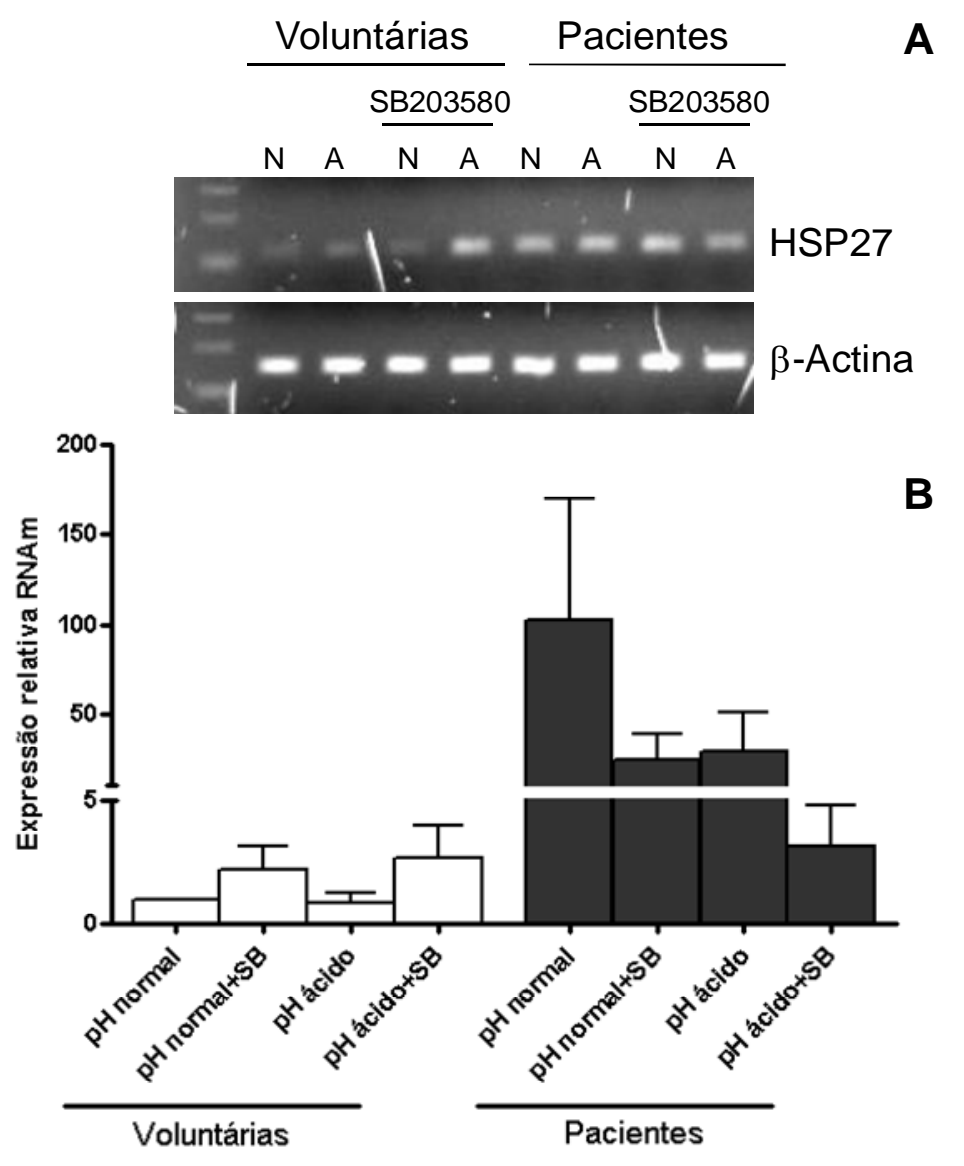

Figura 19- Efeito do inibidor p38MAPK e do ácido lático na expressão do RNAm para HSP27 em DCs derivadas de PBMCs obtidas de voluntárias e de pacientes com cancer de mama. (A) llustração das bandas de cDNA sintetizados a partir de RNA para a proteína HSP27 e da $\beta$-actina extraidas de DCs de voluntárias ou de pacientes, mantidas em cultura com pH normal $(\mathrm{N})$ ou pH ácido $(\mathrm{A})$ na presença ou não do inibidor da p38MAPK. (B) Análise da expressão relativa do RNAm para HSP27 normalizada pela expressão do RNAm da $\beta$-actina utilizando a fórmula do $\Delta \Delta$ Ct. As análises estatísticas foram realizadas pelo teste ANOVA one-way seguido do pós-teste de Bonferroni. 
A co-cultura de DCs derivadas de PBMCs com linhagens tumorais estrógenodependente (MCF-7) e estrógeno-independente (SK-BR-3), em placas de trans-well, induziu a expressão para HSP27 tanto em voluntárias quanto em pacientes (Figura 20). Não foi observado expressão de HSP27 em PBMCs de voluntárias e de pacientes.

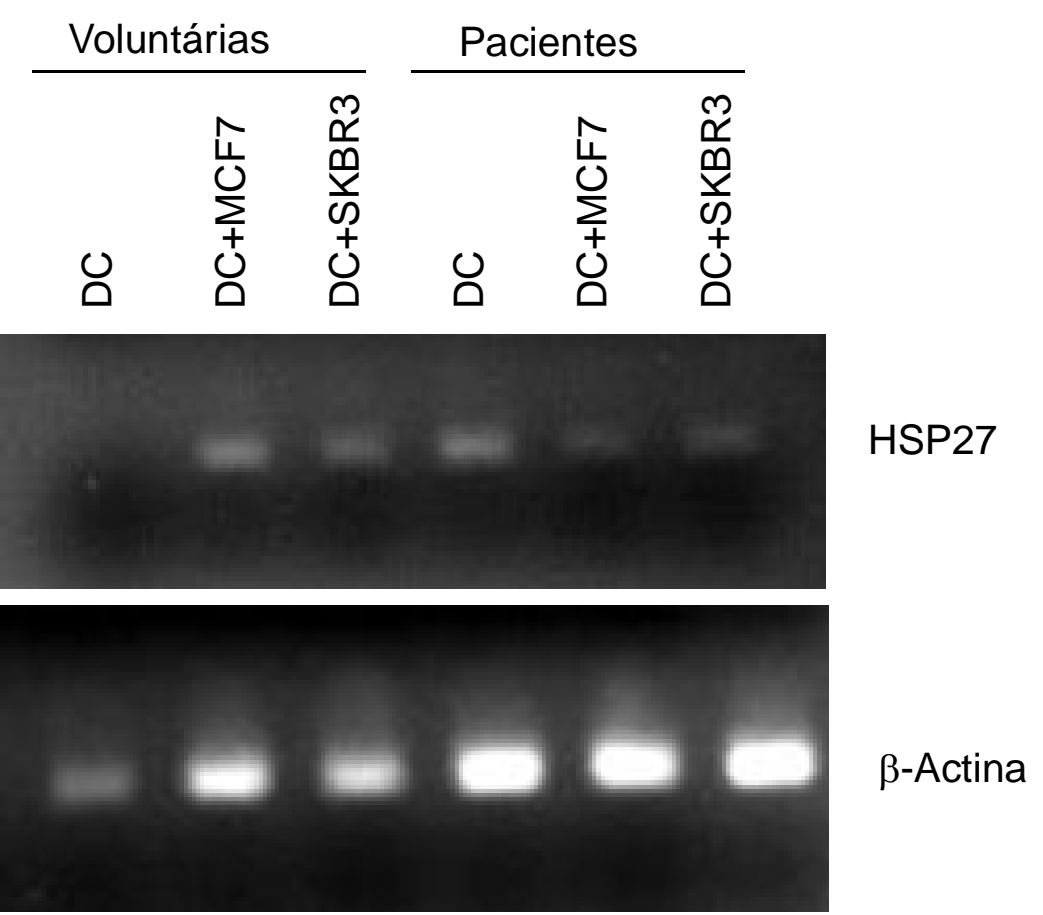

Figura 20- Expressão do RNAm para HSP27 em DCs derivadas de PBMCs obtidas de voluntárias e de pacientes com cancer de mama mantidas em co-cultura com linhagens tumorais de mama. 


\subsection{Avaliação fenotípica e funcional das DCs obtidas de PBMCs de pacientes em tratamento com Tamoxifeno após mastectomia}

Após a mastectomia, para a remoção do tecido mamário afetado pelo tumor, um grupo de pacientes passa a receber tamoxifeno, droga que atua como um modulador dos receptores de estrógeno. Algumas destas pacientes, atendidas no ambulatório do Hospital Pérola Byington para acompanhamento, tiveram amostras de sangue coletadas para a obtenção de PBMCs utilizadas na geração de DCs in vitro.

As pacientes ambulatoriais apresentaram uma redução significativa no número de DCs recuperadas $(7,8 \% \pm 1,4)$, em relação ao total de PBMCs utilizadas na cultura de diferenciação, quando comparadas com as voluntárias saudáveis $(18,9 \% \pm 2,6)$ (Figura 21A). Entretanto, a frequência dos receptores para citocinas IL-4 e GM-CSF nas PBMCs destas pacientes tratadas com tamoxifeno não apresentou diferenças significativas, quando comparadas com PBMCs de voluntárias (Figura 21B).

O fenótipo das DCs diferenciadas de PBMCs destas mesmas pacientes apresentou-se mais próximo ao de células derivadas de doadoras saudáveis, mantendo apenas uma frequência de células CD86+ menor nas pacientes $(67,5 \% \pm$ 8) quando comparadas as voluntárias saudáveis (88,4\% $\pm 2,3)$ (Figura 22). 


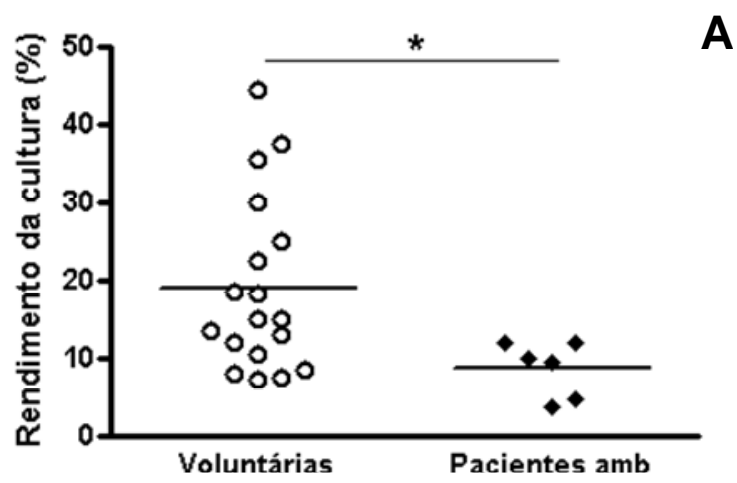

B

\section{$\mathrm{CD}_{14}{ }^{+} \mathrm{CD} 116^{+}$}

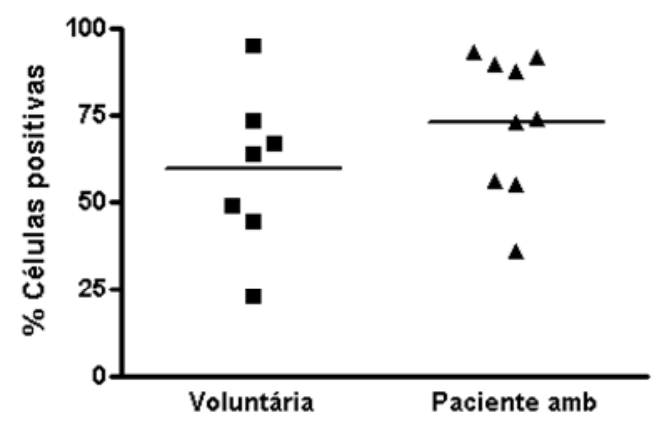

A

$\mathrm{CD}_{14}^{+} \mathrm{CD} 124^{+}$

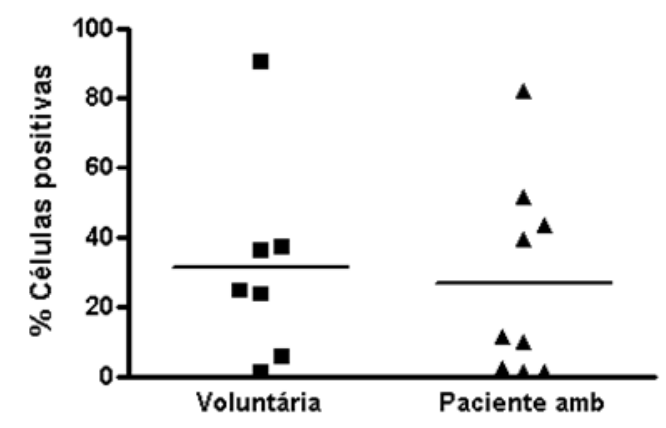

Figura 21- Comparação entre a cultura de DCs derivadas de PBMCs obtidas de voluntárias e de pacientes que sofreram mastectomia e em tratamento com tamoxifeno. (A) Frequência do rendimento de células obtidas ao término da cultura em relação às PBMCs totais submetidas à cultura. (B) Frequência de células positivas para receptor de GM-CSF (CD116) e IL4 (CD124) em PBMCs. As análises estatísticas foram realizadas pelo teste t não pareado; ${ }^{*}=p<0,05$. 
HLA-DR
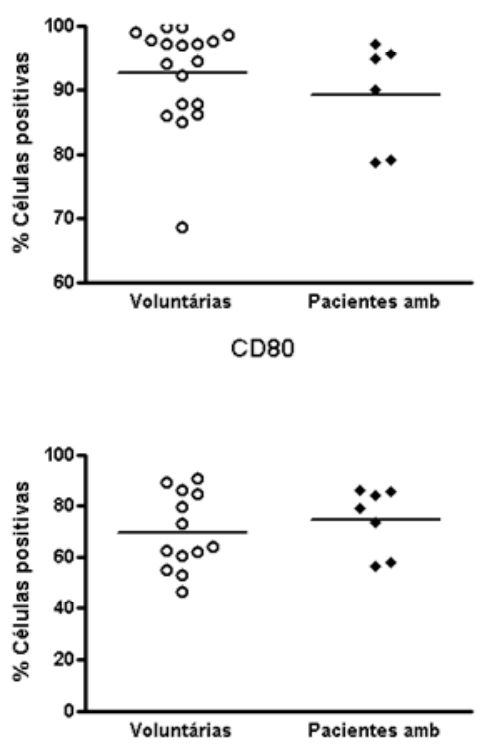

CD11c

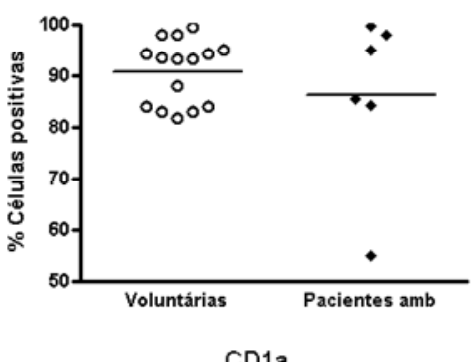

CD1a
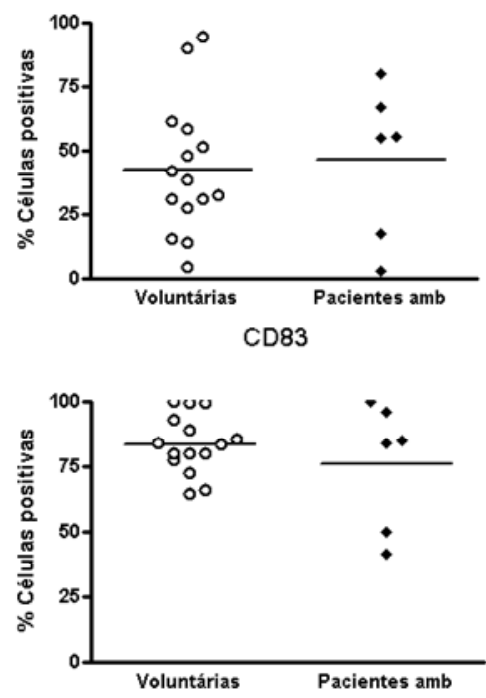

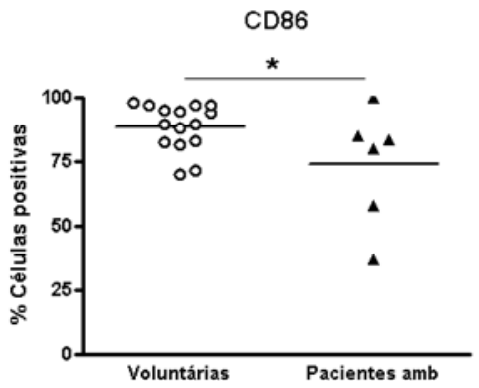

$\mathrm{CD} 40$

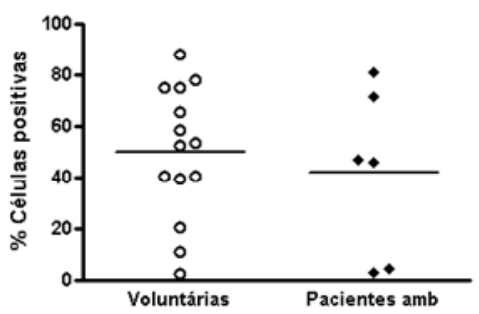

Figura 22- Comparação fenotípica de DCs derivadas de PBMCs obtidas de voluntárias e de pacientes ambulatoriais. A frequência dos marcadores HLA-DR, CD11c, CD80, CD40, CD83 e CD1a não apresentaram diferenças entre os grupos, exceto a expressão de CD86 que foi menor nas pacientes quando comparadas com as voluntárias saudáveis. As análises estatísticas foram realizadas pelo teste t não pareado; * $=p<0,05$. 
$\mathrm{Na}$ análise funcional, os resultados mostraram que o índice de proliferação e a relação de linfócitos $\mathrm{CD}^{+}$e $\mathrm{CD}^{+}$nas pacientes ambulatoriais não apresentou diferença em relação às voluntárias saudáveis e foi significativamente diferente quando comparado com as pacientes antes da mastectomia (Figura 23A e B).

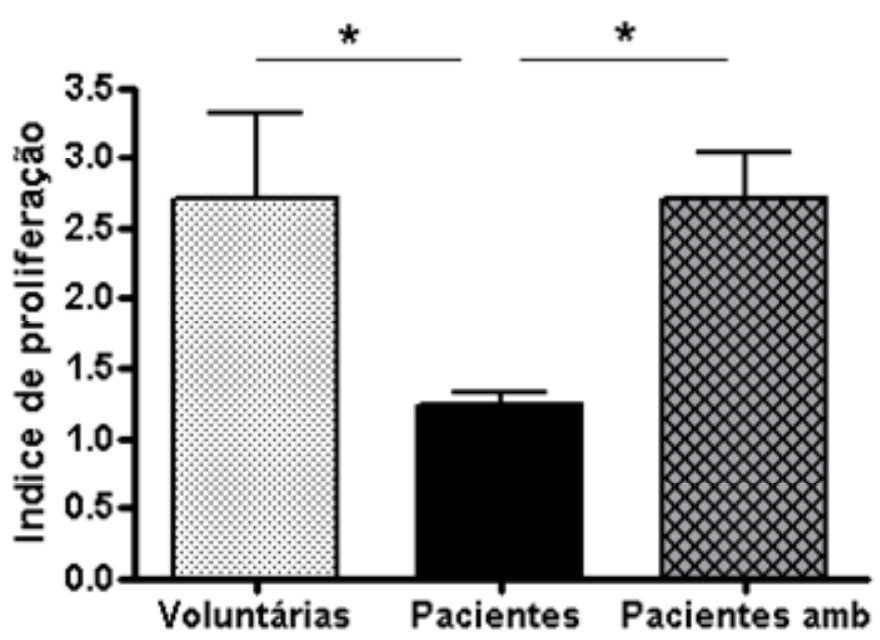

A

B

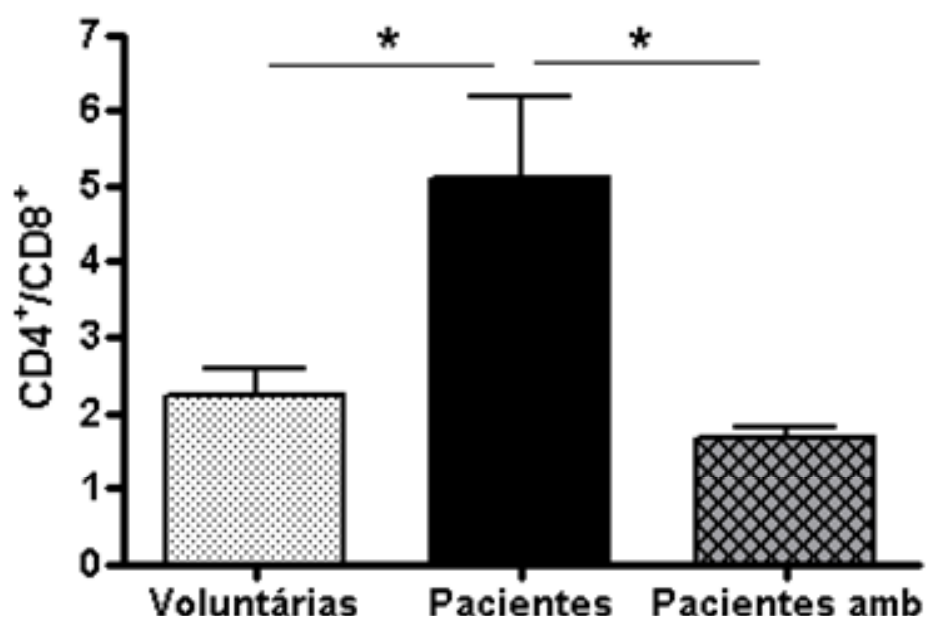

Figura 23- Comparação funcional entre a cultura de DCs derivadas de PBMCs obtidas de voluntárias e de pacientes ambulatoriais. (A) Comparação do índice de proliferação de linfócitos alogenéicos e (B) da relação de linfócitos CD4 e CD8 no ensaio de MRL com DCs obtidas de PBMCs de voluntárias saudáveis, de pacientes com câncer de mama e de pacientes que tiveram o tumor removido e fazem uso do tamoxifeno. As análises estatísticas foram realizadas pelo teste ANOVA one-way com pós-teste Bonferroni; * $=p<0,05$. 


\subsection{Efeito do Tamoxifeno no fenótipo e na função das DCs diferenciadas de PBMCs de voluntárias saudáveis e de pacientes com cancer de mama}

Os resultados obtidos com os experimentos realizados com DCs derivadas de PBMCs de pacientes, que tiveram o tumor removido por mastectomia e tradadas tamoxifeno, mostraram uma melhora fenotípica e funcional. Para verificar se estes efeitos eram estariam sendo causados pelo tratamento com o modulador de estrógeno e/ou pela ausência do tumor, PBMCs de pacientes com carcinoma ductal foram diferenciadas com meio de cultura suplementado com tamoxifeno, tendo como controle as DCs obtidas de PBMCs de voluntárias saudáveis. Os resultados mostraram que o tamoxifeno não modificou o fenótipo das DCs de voluntárias, entretanto nas pacientes os dados mostraram uma tendência a um aumento na população positiva para HLA-DR, CD11c, CD80 e CD86, mas sem significância estatística (Figura 24).

Nos ensaios funcionais de MRL, os resultados mostraram que o tratamento com tamoxifeno não modificou os índices de proliferação, isto é, não modifica a capacidade de induzir linfoproliferação pelas DCs (Figura 25). 
Voluntárias

HLA-DR

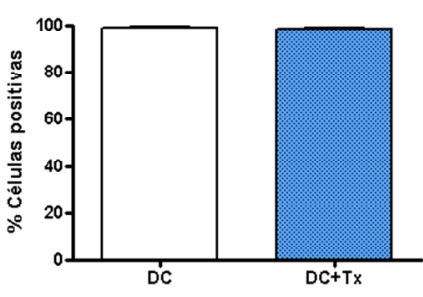

CD11c

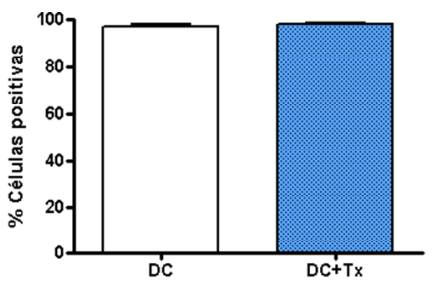

CD80
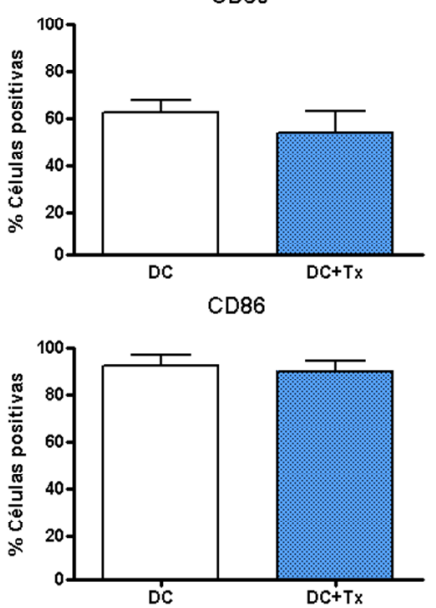

Pacientes

HLA-DR

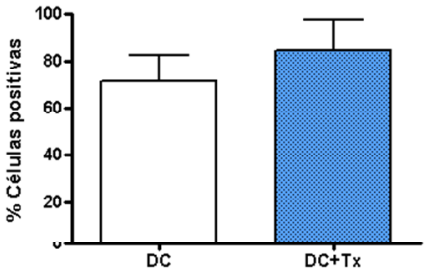

CD11c
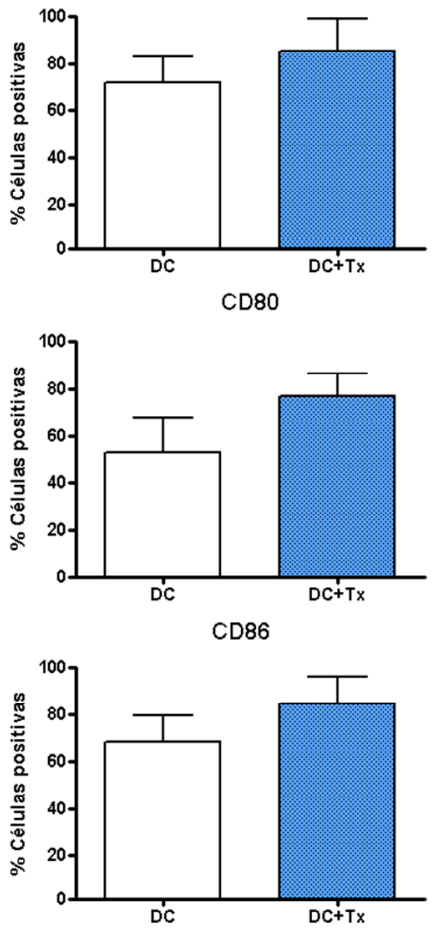

Figura 24- Comparação fenotípica de DCs derivadas de PBMCs obtidas de voluntárias e de pacientes com cancer de mama tratadas com Tamoxifeno (TX). As análises estatísticas foram realizadas pelo teste t não pareado.
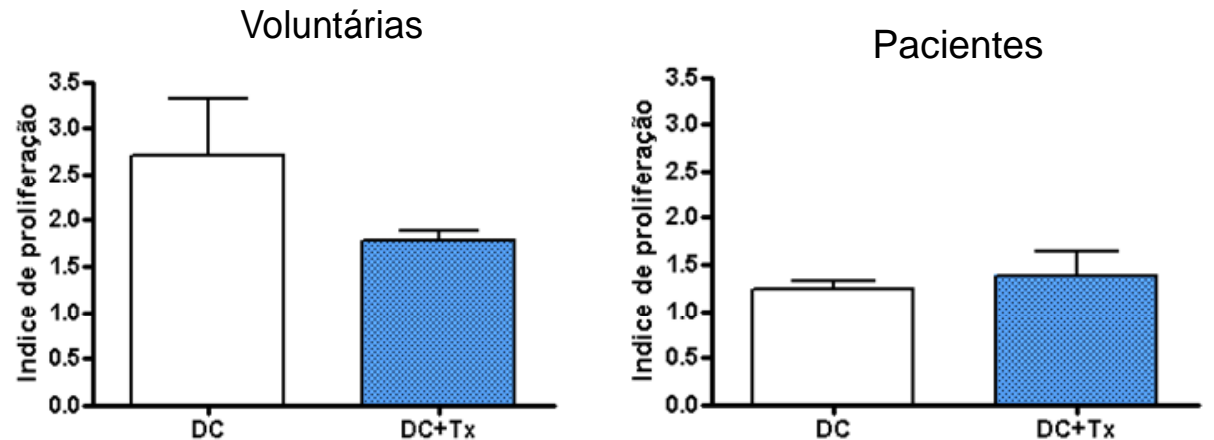

Figura 25- Comparação funional de DCs derivadas de PBMCs obtidas de voluntárias e de pacientes com cancer de mama tratadas com Tamoxifeno (Tx). As análises estatísticas foram realizadas pelo teste t não pareado. 
5 DISCUSSÃO 
O presente trabalho avaliou a diferenciação de DCs a partir PBMCs de pacientes com câncer de mama e de voluntárias saudáveis, comparou suas características fenotípicas e funcionais isoladamente ou com a presença de alguns fatores que participam do microambiente tumoral como a presença de células neoplasicas e de seus fatores solúveis secretados, o ácido láctico e modularodes de receptor de estrógenos e inibidores específicos da p38MAPK.

De acordo com dados relatados na literatura, desde a primeira descrição das DCs feita por Steinman e Cohn (Steinman e Cohn, 1973) até a geração de DCs in vitro através da cultura de células hematopoiéticas com GM-CSF e IL-4, as DCs são definidas como APCs que apresentam uma morfologia típica, que expressa níveis elevados de moléculas do complexo principal de histocompatibilidade (MHC) classe I e classe II, baixos níveis de CD14, alta atividade estimulatória de linfócitos e aumento da sua eficiência com a adição de TNF-a (Inaba et al., 1992; Caux et al., 1992; Sallusto e Lanzavecchia, 1994).

Entretanto, é importante considerar que as DCs se apresentam como uma população heterogênea que desempenham papéis diferentes na resposta imune e que ainda são insuficientes as informações que definem melhor as subpopulações, bem como, suas funções (Naik e Demystifying, 2008; Villadangos e Schnorrer, 2007.).

Desta forma, considerando os monócitos como um potencial precursor das DCs, vários fatores presentes no microambiente durante a diferenciação, como TNF, IL3, IL6, GM-CSF, IFNs, entre outros, podem determinar a heterogeneidade já relatada nas DCs, mesmo in vitro, influenciando a expressão de moléculas coestimuladoras e a produção de citocinas, resultando em interações diversas com outras células do sistema imune, causando ações que podem ir desde tolerância até 
imunogenicidade. (Chomarat, et al., 2003; Chomarat et al., 2000; Encabo et al., 2004; Pulendran et al., 2000; Ito et al., 2001).

Assim, padronizamos o protocolo de diferenciação com meio suplementado com IL4, GM-CSF e TNF $\alpha$ para geração DCs maduras a partir de PBMCs de voluntárias saudáveis com base nos protocolos já desenvolvidos no nosso laboratório. A diferenciação, inicialmente, foi determinada pela morfologia e pelo perfil fenotípico das células antes e depois da cultura, feita por meio da avaliação de vários marcadores que definem o fenótipo e o estado de maturação. Nossos resultados mostraram redução na expressão de CD14 e aumento da expressão de HLA-DR e moléculas co-estimuladoras nas DCs comparadas com as PBMCs, dados estes que concordam com os já descritos na literatura, mostrando que o protocolo de diferenciação usado neste trabalho foi capaz de gerar DCs maduras a partir de PBMCs.

Considerando que em condições patológicas, como no câncer, outros fatores que não participam do processo fisiológico podem estar presentes, foi avaliada a capacidade de geração de DCs in vitro a partir de PBMCs obtidas de pacientes com câncer de mama operável, utilizando o mesmo protocolo de diferenciação descrito para as células de voluntárias saudáveis. Os resultados mostram que as PBMCs de pacientes com carcinoma ductal apresentam capacidade de diferenciação. Ao término da cultura foram observadas células com características típicas de DCs, com a presença de uma população morfologicamente grande e granulosa detectada por citometria de fluxo e o fenótipo composto pela maior expressão de HLA-DR e moléculas co-estimuladoras, como descrito para as DCs diferenciadas de PBMCs de voluntárias saudáveis. 
Devido o fato de que PBMCs obtidas do sangue de pacientes portadores de tumor podem originar DCs defeituosas, a princípio, observamos que foi possível gerar DCs in vitro a partir de PBMCs de pacientes com carcinoma ductal invasivo operável.

Além disso, fizemos um estudo comparativo das DCs obtidas de PBMCs de pacientes com o de voluntárias saudáveis. O perfil fenotípico das DCs de pacientes apresentou uma diminuição no número de células diferenciadas e na expressão de marcadores celulares típicos de DCs ativadas, uma baixa frequência na população de células HLA-DR ${ }^{+}, \mathrm{CD} 11 \mathrm{c}^{+}, \mathrm{CD} 80^{+}, \mathrm{CD} 86^{+}$e $\mathrm{CCR} 7^{+}$que sugerem um prejuízo na formação de APCs competentes.

Gabrilovich et al. (1997) relataram que DCs isoladas diretamente do sangue periférico de pacientes com câncer de mama avançado apresentaram deficiências fenotípicas e funcionais, entretanto, a geração in vitro de DCs a partir de precursores hematopoiéticos presentes no sangue periférico destas pacientes poderiam originar DCs capazes de estimular células $T$, isto é, corrigindo o defeito das DCs quando diferenciadas in vivo.

Entretanto, nossos resultados concordam completamente com os dados descritos por Gervais et al. (2005) relataram que DCs diferenciadas de monócitos obtidos de pacientes com câncer de mama apresentaram uma diminuição na expressão de MHC classe II e na iniciação da capacidade de apresentação de antígenos, e que estes efeitos poderiam estar associados ao microambiente tumoral.

Assim, os dados mostrados neste trabalho indicam que ocorre geração de DCs a partir de PBMCs isoladas de pacientes com carcinoma ductal invasivo operável, mas estas DCs apresentam defeitos sutis na sua diferenciação que podem ser consequência de uma menor responsividade das células precursoras aos 
estímulos de diferenciação e maturação em DCs provocadas pela presença do tumor.

Podemos dizer também que, ainda hoje, a literatura apresenta alguns pontos que divergem quanto à eficácia das DCs diferenciadas in vitro a partir de PBMCs de pacientes com câncer de mama e estas diferenças podem estar relacionadas com o tipo e estadiamento o tumor, bem como, com o protocolo usado para a geração de DCs.

Nossos dados sugerem também que, as DCs de pacientes com câncer de mama são afetadas pelo microambiente tumoral, onde o tumor seria capaz de criar um microambiente inóspito para a diferenciação e/ou maturação das DCs, o que gera, como consequência, uma menor capacidade de apresentação de antígenos por estas APCs e menor resposta específica antitumoral, fato que também foi relatado em DCs obtidas de pacientes com outros tipos de tumores ou em diversos estágios da doença (Ninomiya et al., 1999; Ratta et al., 2002; Dallal et al., 2002; Neves et al., 2005; Pinzon-Charry et al., 2007; Sun et al., 2008; Baleeiro et al., 2008).

Juntamente com as alterações fenotípicas, em ensaios funcionais também foram observadas diferenças relevantes na capacidade de estimulação de linfócitos T alogenéicos pelas DCs, que foi significativamente menor nas células de pacientes com câncer de mama, com uma relação maior de linfócitos $\mathrm{CD}^{+}$para $\mathrm{CD} 8 .^{+} \mathrm{Na}$ produção de citocinas, o sobrenadante de co-cultura de DCs de pacientes com linfócitos alogenéicos mostrou um a produção de IL-10 maior, enquanto que a produção de IFN- $\gamma$ foi significativamente menor quando comparado com as voluntárias. 
Alguns trabalhos têm demonstrado a importância das DCs na "polarização" de células Th naive capazes de secretar padrões de citocinas bem diferentes e, conseqüentemente, modificar a resposta imune inclusive no câncer de mama (Matsuura et al., 2006; Feili-Hariri et al., 2006). A síntese da IL-10 pode ser feita por células T CD4+ ou CD8+, monócitos, macrófagos, células B ativadas, queratinócitos e linfomas, é uma citocina produzida relativamente tarde na seqüência de ativação de células T ou monócitos / macrófagos, em comparação a outras citocinas, que pode ser um aspecto importante da IL - 10 de inibir a capacidade ativação das células T e macrófagos (Moore et al., 1993). Já o IFN- $\gamma$ é secretado principalmente por linfócitos Th1 e apresentam um importante papel na resposta imune antitumoral (Brandacher et al., 2006).

Nossos dados mostraram que as DCs de pacientes parecem induzir um padrão de reposta imune completamente diferente quando comparado com DCs de voluntárias. Considerando que estas APCs apresentam a habilidade de dirigir a resposta imune no momento da apresentação do antígeno para os linfócitos T e das citocinas dosadas que são produzidas por eles, os achados sugerem que as DCs das pacientes induzem um padrão de linfócitos tolerogênicos, enquanto que as DCs de voluntárias induzem um padrão de resposta de linfócitos $T$ efetores. Além do resultado em si, destacamos a importância da diversificação de experimentos para melhor avaliação funcional das DCs.

Assim, sugerimos que as DCs derivadas de PBMCs de voluntárias saudáveis apresentam-se plenamente maduras, enquanto que as diferenças fenotípicas e funcionais encontradas nas DCs diferenciadas de PBMCs de pacientes fazem com que as mesmas expressem um fenótipo imaturo. Estas alterações encontradas nas DCs de pacientes poderiam ser capazes de alterar a sinalização celular, de forma 
que há moléculas de membrana suficientes para ativar os linfócitos, entretanto, causando um padrão de resposta completamente diferente. Estudo sobre a relação entre a função e o estado de maturação das DCs mostrou que: DCs maduras são capazes de induzir uma maior proliferação de linfócitos T CD4+, em contraste, DCs imaturas reduzem a proliferação de linfócitos, inibem secreção de IFN- $\gamma$, IL-2 e IL-4 e aumentam a secreção de IL-10 (Jonuleit et al., 2000).

De acordo com os resultados encontrados, mesmo recebendo todos os estímulos necessários para a geração de uma DC madura, as DCs diferenciadas de PBMCs de pacientes com câncer de mama parecem apresentar um caráter de DC imatura, quando comparado com PBMCs de voluntárias saudáveis. Tal fato poderia ser justificado pelo fenótipo e pelo padrão de citocina encontrado, que reforça uma possível tolerância das células progenitoras aos estímulos de diferenciação e de maturação. Estes resultados podem ter relação com a menor expressão de receptores para IL4 e GM-CSF em PBMCs de pacientes com cancer, gerando DCs, mas com prejuízo fenotípico e/ou funcional, já que, segundo Sallusto e Lanzavecchia (1994) a combinação de GM-CSF e IL-4 na cultura proporcionam condições para a geração de células com características fenotípicas e propriedades funcionais de DCs. Os dados sugerem mais uma vez que, a presença do tumor é um fator relevante, onde já foi descrito na literatura que o tumor pode influenciar não só as DCs, mas também seus precursores, interferindo na sua capacidade de diferenciação (Encabo et al., 2004; Neves et al., 2005; Bharadwaj et al., 2007).

Apesar de alguns protocolos de imunoterapia antitumoral com DCs utilizarem células precursoras do próprio paciente para fazer a diferenciação em DCs in vitro (Jacobs et al., 2007), se consideramos os dados encontrados para pacientes com carcinoma ductal mamário, eles sugerem que as DCs das próprias pacientes 
diferenciadas in vitro a partir de PBMCs possam ser ineficientes para a geração de uma resposta imune efetora e, portanto, utilizá-las como ferramenta no desenvolvimento de uma vacina terapêutica seria

Tendo a presença do tumor como um fator essencial na indução das modificações fenotípicas e funcionais nas DCs, avaliamos o contato célula-célula, através da presença de células tumorais de linhagens de adenocarcinoma de mama (MCF-7 e SK-BR-3) irradiadas e adicionadas diretamente a cultura de DC durante sua ativação, bem como, a ação de fatores solúveis, por meio da co-cultura de celulas tumorais e DCs em placa transwell. Os resultados mostraram uma redução significativa na freqüência de células positivas com fenótipo de DC madura, uma tendêcia de redução na capacidade de induzir a proliferação de células $T$ com aumento na concentração de IL10 na co-cultura de linfócitos com DCs diferenciadas com SK-BR-3, mas não com MCF-7.

A linhagem MCF7 apresenta características do epitélio mamário incluindo a capacidade de processar estradiol via receptores citoplasmáticos (http://icbp.lbl.gov/breastcancer), a SK-BR-3 é uma linhagem de adenocarcinoma de mama, que não apresenta receptor de E2 e que super expressa o produto do gene que codifica o receptor de fator de crescimento de epiderme 2 (HER2/c-erb-2). O HER2/c-erb-2 faz parte da família dos receptores de membrana de tirosina quinase que regula o crescimento e a proliferação celular importante na tumorigenese do câncer de mama, sendo alvo de terapias (Zhou et al., 2002) inclusive na elaboração de vacinas (Stojadinovic et al., 2007). A super expressão do HER2/c-erb-2 confere maior agressividade as células tumorais por favorecer o desenvolvimento do tumor e conferir resistência a hormonioterapia (Albert et al., 1998). 
Os nossos resultados sugerem que o tipo de linhagem tumoral pode induzir efeitos diferentes sobre as DCs, e uma das características das células tumorais que pode está envolvida nestes efeitos seria a expressão HER2/c-erb-2 pela linhagem SK-BR-3, modificando de alguma forma a maturação das DCs que não foi observada com a linhagem MCF-7. Tais efeitos sobre o sistema imune podem contribuir para as caracteríticas que determinam maior ou menor agressividade do tumor.

As células tumorais são capazes de produzir ácido láctico de forma exacerbada em decorência das alterações sofridas pelo metobolismo energético (Warburg, 1961). Assim, o ácido láctico é um exemplo de molécula secreteda pelo tumor que compõem o microambiente podendo afetar a diferenciação de PBMCs em DCs. Puig-Kröger et al., (2003) mostraram que o lactato de sódio, presente na solução de diálise peritoneal, era capaz de prejudicar o fénotipo e a função de DCs maduras por inibir a ativação do NFאB. Em cultura tridimensional de melanoma, as DCs originadas de monócitos infiltrantes aprentaram alterações fenotípicas, onde foi observado no sobrenadante, altas concentrações de lactato. As culturas de DCs acidificadas mostraram as mesmas alterações fenotípicas das DCs diferenciadas de monócitos infiltrados no tumor e o bloqueio do ácido láctico na cultura originou DCs com fenótipo normal, sugerindo uma ação moduladora sobre fenótipo das DCs presentes no ambiente tumoral, o que pode contribuir para os mecanismos de evasão (Gottfried et al., 2006).

Desta forma avaliamos a capacidade de diferenciação de PBMCs, de voluntárias e de pacientes, em DCs mantidas em cultura com meio acidificado com ácido láctico. Nossos resultados mostraram que o ambiente ácido inibe a diferenciação e maturação das DCs e reforça a diferença existente entre células de 
voluntárias e pacientes, mostrando que nas células precursoras obtidas das pacientes o efeito inibitório foi marcante.

Com base nos resultados mostrados, o microambiente tumoral parece impor uma condição estressante capaz de alterar a capacidade das PBMCs de se diferenciar em DCs. A via p38MAPK é uma das vias mais bem descritas responsáveis em estabilizar as células em condições de estress. Em células epiteliais a hipóxia tem como um dos mecanismos a ativação da via das p38MAPK que eleva a fosforilação da Proteína de Choque Térmico (HSP) 27 que atua no citoesqueleto, altera a permeabilidade celular e regula os mecanismos de apoptose (Liu et al., 2009). Algumas HSPs apresentam efeitos sobre o sistema imune, entre elas, a HSP27 é capaz de atuar sobre os monócitos provocando efeitos antiinflamatórios mediados pela secreção de IL10 e pela modificação na capacidade de diferenciação dos monócitos em DCs, promovendo um "anti-sinal de perigo" (Miller-Graziano et al., 2008).

Uma das hipóteses especuladas neste trabalho seria de que muitos dos efeitos inibitórios, observados ex vivo, sobre as DCs seria causado pelo microambiente tumoral devido a indução da síntese da HSP27, já descrita como capaz de interferir nos mecanismos de diferenciação dos monócitos em DCs. Devido as PBMCs das pacientes já estarem em contato com este microambiente in vivo isso causaria um aumento da susceptibilidade nas DCs das pacientes às diversas condições testadas. Assim, o microambiente tumoral, formado por células tumorais, elementos solúveis secretados como o ácido láctico, poderia funcionar como um meio estressante, ativando a via das p38MAPKs provocando a síntese da HSP27, que poderia ser responsável pelas falhas na maturação e na diferenciação, na 
indução na secreção de IL10 e, conseqüentemente, o não desenvolvimento de imunogenicidade antitumoral.

Os resultados mostraram que as DCs diferenciadas de PBMCs de pacientes apresentaram uma expressão elevada de HSP27, quando comparadas com as voluntárias, sugerindo que há ativação da via p38MAPK em resposta ao ambiente inóspito.

Já foi descrito na literatura que alguns tipos de tumores, inclusive o de mama, apresentam elevada expressão da HSP27, podendo estar envolvida com o desenvolvimento e resistência do tumor e tendo aplicação como um marcador de diagnóstico (Garrido et al., 1998; Rui et al., 2003; Ciocca e Calderwood 2005; Kang, et al., 2008). Entretanto, nossos resultados são inéditos quanto a expressão elevada da HSP27 em DCs de pacientes com cancer de mama e sua possível relação com as alterações no fenótipo e na função destas APCs.

Quando as PBMCs foram tratadas com o inibidor da p38MAPK (SB203580) e induzidas à diferenciação, foi observado uma redução na expressão da HSP27 quando comparada com as células sem o inibidor, entretanto a expressão ainda foi maior que o observado nas voluntárias saudáveis, sugerindo uma super expressão da via.

Entretanto, nossos resultados mostraram que o bloqueio da via p38MAPK nas voluntárias causou uma perda do fenótipo maduro, tendeu a reduzir a capacidade de linfoproliferação, elevou a relação de $\mathrm{CD}^{+} / \mathrm{CD} 8^{+}$e reduziu a produção de IFN- $\gamma$. Estes dados colaboram com outros relatos da literatura, onde, a via da p38MAPK é uma via de sinalização importante para a expressão de antígenos, para a produção de citocinas e capacidade aloestimulatória em DCs derivadas de monócitos (Nakahara et al., 2006). 
Como a via da p38MAPK também é ativada com a hipóxia (Liu et al., 2009) e um dos produtos desta condição é o ácido lático, o utilizamos como um agente estressante e que está presente no microambiente tumoral. Os resultados mostraram que há um prejuízo fenotípico principalmente nas DCs de pacientes,

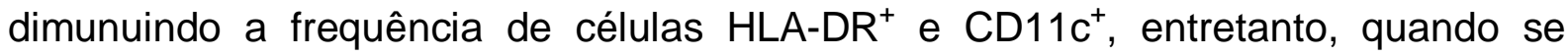
analisa a expressão da HSP27, os dados mostram que ele não se altera nas voluntárias e que reduz a expressão nas pacientes.

Assim, podemos supor que o efeito inibitório do ácido lático não parece ser mediado por esta via de sinalização da p38MAPK, visto que, mesmo tendo um fenótipo prejudicado, a expressão da HSP27 não se elevou, muito pelo contrário, a acidez parece atuar como um bloqueador da expressão desta chaperona, que se reduz mais ainda quando combinado com o inibidor específico da p38MAPK (SB203580). Entretanto como as alterações fenotípicas foram significantes nas pacientes, não excluimos uma ação inibitória sinérgica do meio ácido com a HSP27, possivelmente, já presente na célula.

A via da p38MAPK é importante para a diferenciação de monóctos em DCs. Segundo Hercus et al. (2009), o receptor de GM-CSF é um receptor pleiotrópico em que sua via de sinalização envolve uma família de proteínas Jaks (quinase de Janus) e STATs (Transdutores de sinal e ativadores de transcrição) capazes de ativar vários substratos como o Shc (do inglês Src homology collagen) com a ativação das MAPKs. Poderando a importância dos receptores de IL4 e GM-CSF, supomos que por meio destes receptores pode haver a ativação da p38MAPK que participa da sinalização para a diferenciação de monócitos em DCs. Entretanto este mecanismo fisiológico pode gerar uma produção de HSP27 constitutiva, sem alterar a capacidade de geração de DCs competentes. 
Nossos resultados mostraram que quando as DCs de voluntárias foram mantidas em cultura com MCF-7 ou SK-BR-3 houve a expressão de HSP27, e a indução desta proteína ocorre durante a diferenciação, já que, não foi observada uma expressão significativa da HSP27 nas PBMCs, tanto em voluntárias quanto em pacientes. Desta forma, a exposição do monócito ao microambiente tumoral, capaz de ativar a via p38MAPK, associado à baixa expressão dos receptores de IL4 e GMCSF pode induzir um aumento da produção de HSP27, onde a sinergia entre a falha na sinalização pelas citocinas e a resposta ao estresse, com a síntese da chaperona, pode alterar os mecanismos celulares de diferenciação, gerando DCs com características mais imaturas (Figura 26).

\section{$\underline{\text { Voluntárias }}$}
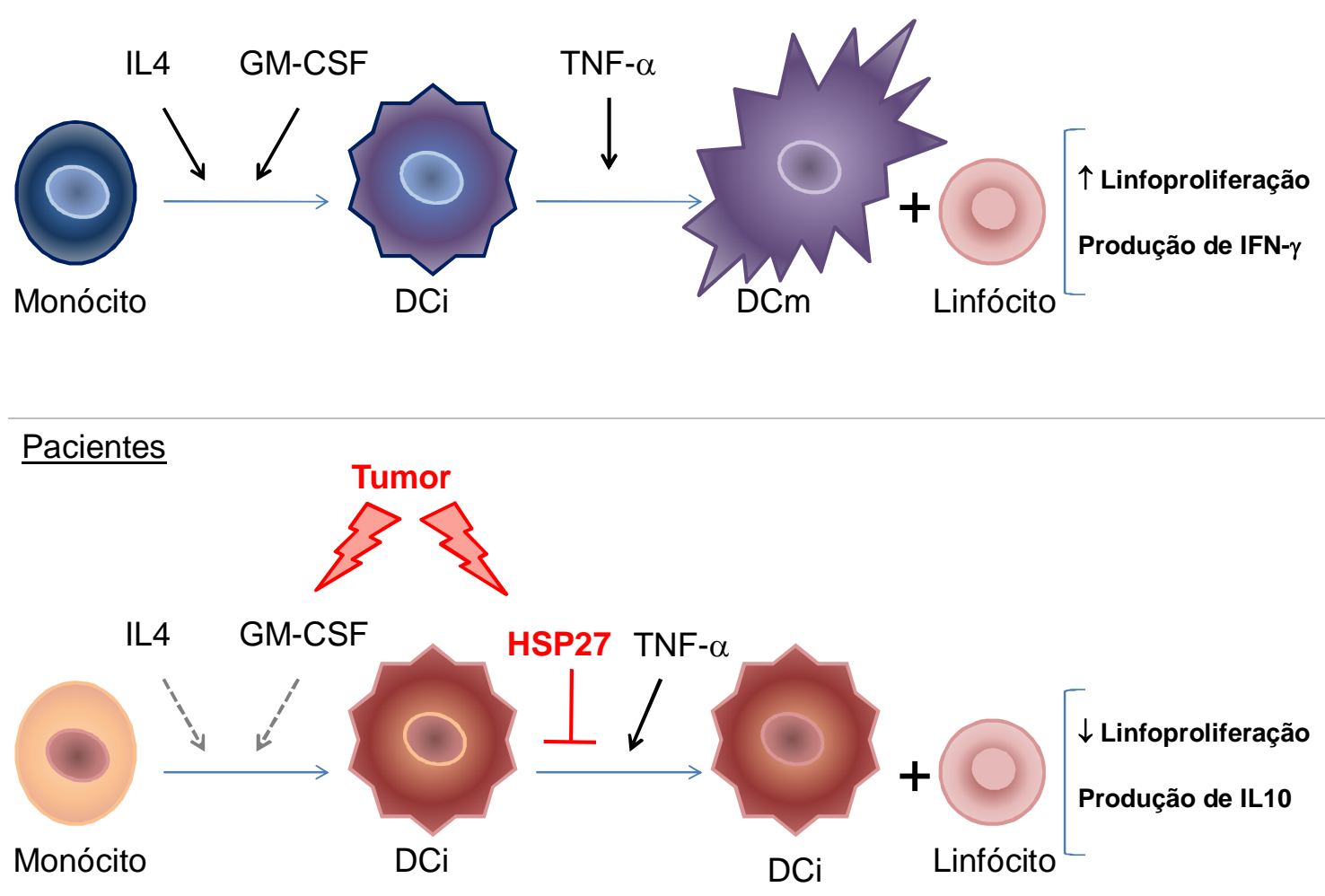

Figura 26- Esquema hipotético das interações dos fatores do microambiente tumoral sobre a diferenciação das DCs a partir de PBMCs de voluntárias saudáveis e de pacientes com câncer de mama. 
Outro dado que reforça a idéia do efeito do microambiente na capacidade das PBMCs de se diferenciarem em DCs foi observado nas pacientes que tivem o tumor removido e faziam uso do Tamoxifeno. Os resultados mostraram que, mesmo com um rendimento inferior ao das voluntárias saudáveis, as características fenotípicas e funcionais apresentaram uma melhora. Entretanto o tratamento com o tamoxifeno é um fator que não pode ser ignorado. Assim, a cultura de DCs derivadas de PBMCs de pacientes com câncer foi suplementada com tamoxifeno, e este, não corrigiu as falhas fenotípicas já descritas nas células de pacientes com câncer operável. Muito pelo contrário, no uso dos moduladores específicos de receptor de estrógeno seriam capazes de inibir a capacidade imunoestimuladora das DCs que apresentariam um fenótipo mais imaturo (Nalbandian et al., 2005).

Assim, as DCs são "alvos" do microambiente tumoral, evidenciado pelas células obtidas de pacientes com câncer de mama, que apresentaram maior susceptibilidade aos efeitos inibitórios quando comparadas com células obtidas de voluntárias saudáveis. Além disso, os resultados sugerem os efeitos causados pelos fatores solúveis do tumor não se limitam apenas a células já diferenciadas, podendo também interferir com as células precursoras de DCs, sendo um possível mecanismo de evasão interferindo com as células imunes antes mesmo de elas chegarem ao tecido tumoral, principalmente as APCs, impedindo o desenvolvimento de uma resposta tumor-específica. 
6 CONCLUSÕES 
- As análises fenotípicas de células derivadas do tumor mostraram uma expressão de CD83 maior que outros marcadores de DCs, e pela imunohistoquímica, mostra a presença delas infiltardas no tumor em regiões intra e peritumorais.

- PBMCs de pacientes com câncer de mama operável e voluntárias saudáveis são capazes de diferenciar-se em DCs em cultura suplementada com IL4, GM-CSF e TNF- $\alpha$, entretanto as DCs de pacientes apresentaram alterações fenotípicas e funcionais. Estes resultados podem estar relacionados a menor expressão de receptores para IL4 e GM-CSF nas PBMCs de pacientes.

- DCs obtidas de PBMCs de pacientes apresentaram aterações fenotípicas com menor expressão de HLA-DR, CD11c e moléculas co-estimuladoras (CD80 e CD86) e CCR7, reduz a capacidade aloestimuladora e apresenta um padrão de citocina imunossuperssor

- Nos ensaios de co-cultura de DCs com linhagem tumoral (MCF-7 e SK-BR-3), a presença da célula tumoral e seus fatores solúveis modificaram na capacidade de maturação de DCs a partir de PBMCs, aumentaram a relação de células $C D 4^{+}$para $\mathrm{CD}^{+}$e concentração de IL10 na co-cultura de DCs e linfócitos alogenéicos.

- O pH ácido modificou a capacidade das PBMCs se diferenciarem em DCs nas pacientes, sugerindo maior sensibilidade a modificação do pH.

- O bloqueio da via da p38MAPK causou prejuízo no fenótipo e na produção de IFN- $\gamma$ nas células das voluntárias.

- A HSP27 encontra-se mais expressa nas DCs diferenciadas de PBMCs de pacientes, podendo estar relacionado à via de ativação de estresse p38MAPK. 
- A ausência do tumor nas pacientes tratadas com tamoxefeno apresentou melhora fenotípica e funcional das DCs, entretanto, a presença do tamoxifeno na cultura de DCs de pacientes com tumor não reverteu completamente as alterações fenotípicas e funcionais, sugerindo que a presença do tumor interfere na diferenciação de PBMCs em DCs.

- As alterações fenotípicas e funcionais observadas nas DCs podem ser provocadas pela presença de fatores que compõe o microambiente tumoral, atuando como um fator estressante capaz de influenciar negativamente a capacidade de geração de DCs competentes. 
REFERÊNCIAS 
Adema GJ, Hartgers F, Verstraten R, De Vries E, Marland G, Menon S, Foster J, Xu Y, Nooyen P, McClanahan T, Bacon KB, Figdor CG. Dendritic-cell-derived C-C chemokine that preferentially attracts naive T cells. Nature. 1997;387(6634):713-717.

Albert ML, Sauter B, Bhardwaj N. Dendritic cells acquire antigen from apoptotic cells and induce class I-restricted CTLs. Nature. 1998;392 (6671)86-89.

Moghrabi N, Andersson S. Physiology and molecular genetics of 17 betahydroxysteroid dehydrogenases. Steroids. 1997;62(7)143-147.

Ansar Ahmed S, Dauphinee MJ, Talal N. Effects of short-term administration of sex hormones on normal and autoimmune mice. J Immunol. 1985;134(1) 204-210.

Ansar Ahmed S, Penhale WJ, Talal N. Sex hormones, immune responses, and autoimmune diseases: mechanisms of sex hormone action. Am $\mathrm{J}$ Pathol. $1985 ; 121(3) 531-551$.

Baleeiro RB, Anselmo LB, Soares FA, Pinto CA, Ramos O, Gross JL, Haddad F, Younes RN, Tomiyoshi MY, Bergami-Santos PC, Barbuto JA. High frequency of immature dendritic cells and altered in situ production of interleukin-4 and tumor necrosis factor-alpha in lung cancer. Cancer Immunol Immunother. 2008;57(9)13351345.

Baleeiro RB, Bergami-Santos PC, Tomiyoshi MY, Gross JL, Haddad F, Pinto CA, Soares FA, Younes RN, Barbuto JA. Expression of a dendritic cell maturation marker CD83 on tumor cells from lung cancer patients and several human tumor cell lines: is there a biological meaning behind it? Cancer Immunol Immunother. 2008;57(2)265270.

Banchereau J, Briere F, Caux C, Davoust J, Lebecque S, Liu YJ, Pulendran B, Palucka K.Immunobiology of dendritic cells. Annu Rev Immunol. 2000;18:767-811.

Banchereau J, Palucka AK. Dendritic cells as therapeutic vaccines against cancer. Nat Rev Immunol. 2005;5(4)296-306.

Banchereau J, Steinman RM. Dendritic cells and the control of immunity. Nature.1998;392(6673)245-252.

${ }^{*}$ De acordo com:

International Committee of Medical Journal Editors Uniform requimrements for manuscripts submitted to Biomedical Journal: sample references. Available from:

Htpp://www.icmje.org[2007 May 22] 
Bentrem DJ, Craig JV. Tamoxifen, raloxifene and the prevention of breast cancer. Minerva Endocrinol. 2002;27(2)127-139.

Bergami-Santos PC, Mariano M, Barbuto JA. Dual role of polymorphonuclear neutrophils on the growth of Ehrlich ascites tumor (EAT) in mice. Life Sci. 2004;75(2) 245-255.

Beyaert R, Cuenda A, Vanden Berghe W, Plaisance S, Lee JC, Haegeman G, Cohen $\mathrm{P}$, Fiers $\mathrm{W}$. The $\mathrm{p38} / \mathrm{RK}$ mitogen-activated protein kinase pathway regulates interleukin-6 synthesis response to tumor necrosis factor. EMBO J. 1996;15(8)19141923.

Bharadwaj U, Li M, Zhang R, Chen C, Yao Q. Elevated Interleukin-6 and G-CSF in Human Pancreatic Cancer Cell Conditioned Medium Suppress Dendritic Cell Differentiation and Activation. Cancer Res. 2007;67(11)5479-5488.

Bouman A, Heineman MJ, Faas MM. Sex hormones and the immune response in humans. Hum Reprod Update. 2005;11(4)411-423.

Brandacher G, Winkler C, Schroecksnadel K, Margreiter R, Fuchs D. Antitumoral activity of interferon-gamma involved in impaired immune function in cancer patients. Curr Drug Metab. 2006;7(6)599-612.

Brigati C, Noonan DM, Albini A, Benelli R. Tumors and inflammatory infiltrates: friends or foes? Clin Exp Metastasis. 2002;9(3)247-258.

Caux C, Massacrier C, Vanbervliet B, Dubois B, Van Kooten C, Durand I, Banchereau J. Activation of human dendritic cells through CD40 cross-linking. J Exp Med. 1994;180(4)1263-1272.

Caux C, Moreau I, Saeland S, Banchereau J. Interferon-gamma enhances factordependent myeloid proliferation of human CD34+ hematopoietic progenitor cells. Blood. 1992;79(10)2628-2635.

Chang L, Karin M. Mammalian MAP kinase signalling cascades. Nature. 2001;410(1)37-40.

Cheng ZN, Zhou HH. Contribution of genetic variations in estradiol biosynthesis and metabolism enzymes to osteoporosis. Acta Pharmacol Sin. 2000;21(7)587-590.

Chomarat P, Dantin C, Bennett L, Banchereau J, Palucka AK. TNF skews monocyte differentiation from macrophages to dendritic cells. J. Immunol. 2003;171(5)22622269. 
Chomarat P, Banchereau J, Davoust J, Palucka AK. IL-6 switches the differentiation of monocytes from dendritic cells to macrophages. Nat Immunol. 2000;1(6)510-514.

Chomczynski P, Sacchi N. Single-step method of RNA isolation by acid guanidinium thiocyanate-phenol-chloroform extraction. Anal Biochem. 1987;162(1)156-159.

Ciocca R, Calderwood SK. Heat shock proteins in cancer: diagnostic, prognostic, predictive, and treatment implications. Cell Stress \& Chaperones. 2005;10(2)86103.

Coussens LM, Werb Z. Inflammation and cancer. Nature. 2002;420(6917)860-867.

Coventry BJ, Lee PL, Gibbs D, Hart DN. Dendritic cell density and activation status in human breast cancer CD1a, CMRF-44, CMRF-56 and CD-83 expression. $\mathrm{Br} \mathrm{J}$ Cancer. 2002;86(4)546-551.

Cuenda A, Rouse J, Doza YN, Meier R, Cohen P, Gallagher TF, Young PR, Lee JC. SB 203580 is a specific inhibitor of a MAP kinase homologue which is stimulated by cellular stresses and interleukin-1. FEBS Letters. 1995;364(1)229-233.

Cutler CW, Jotwani R, Pulendran B. Dendritic cells: immune saviors or Achilles' heel? Infect Immun. 2001;69(8)4703-4708.

Dallal RM, Christakos P, Lee K, Egawa S, Son YI, Lotze MT. Paucity of dendritic cells in pancreatic cancer. Surgery. 2002;131(2)135-138.

De AK, Kodys KM, Yeh BS, Miller-Graziano C. Exaggerated human monocyte IL-10 concomitant to minimal TNF-a induction by heatshock protein 27 (HSP27) suggests HSP27 is primarily an antiinflammatory stimulus. J. Immunol. 2000;165(7)39513958.

Doisneau-Sixou SF, Sergio CM, Carroll JS, Hui R, Musgrove EA, Sutherland RL. Estrogen and antiestrogen regulation of cell cycle progression in breast cancer cells. Endocr Relat Cancer. 2003;10(2)179-186.

Dong C, Davis RJ, Flavell RA. MAP kinases in the immune response. Annu Rev Immunol. 2002;20:55-72.

Douin-Echinard V, Laffont S, Seillet C, Delpy L, Krust A, Chambon P, Gourdy P, Arnal JF, Guéry JC. Estrogen receptor alpha, but not beta, is required for optimal dendritic cell differentiation and [corrected] CD40-induced cytokine production. J Immunol. 2008;180(6)3661-3669. 
Dunn GP, Bruce AT, Ikeda H, Old LJ, Schreiber RD. Cancer immunoediting: from immunosurveillance to tumor escape. Nat Immunol. 2002;3(11)991-998.

Dunn GP, Old LJ, Schreiber RD. The immunobiology of cancer immunosurveillance and immunoediting. Immunity. 2004;21(2)137-148.

Encabo A, Solves P, Mateu E, Sepulveda P, Carbonell-Uberos F, Minana MD. Selective generation of different dendritic cell precursors from CD34+ cells by interleukin-6 and interleukin-3. Stem Cells. 2004;22(5)725-740.

English MA, Kane KF, Cruickshank N, Langman MJ, Stewart PM, Hewison M. Loss of estrogen inactivation in colonic cancer. J Clin Endocrinol Metab. 1999;84(6)20802085.

Fabian CJ. Breast cancer chemoprevention: beyond tamoxifen. Breast Cancer Res. 2001;3(2)99-103.

Feili-Hariri M, Flores RR, Vasquez AC, Morel PA. Dendritic cell immunotherapy for autoimmune diabetes. Immunol Res. 2006;36(1-3)167-173.

Freshney NW, Rawlinson L, Guesdon F, Jones E, Cowley S, Hsuan J, Saklatvala J. Interleukin-1 activates a novel protein kinase cascade that results in the phosphorylation of Hsp27. Cell. 1994;78(6)1039-1049.

Fukao T. Dendritic-cell-based anticancer vaccination: has it matured? Trends Immunol. 2002;23(5)231-232.

Gabrilovich DI. Dendritic cell vaccines for cancer treatment. Curr Opin Mol Ther. 2002; 4(5)452-458.

Gabrilovich DI, Corak J, Ciernik IF, Kavanaugh D, Carbone DP. Decreased antigen presentation by dendritic cells in patients with breast cancer. Clin Cancer Res. 1997;3(3)483-490.

Garrido C, Fromentin A, Bonnotte B, Favre N, Moutet M, Arrigo AP, Mehlen P, Solary E. Heat Shock Protein 27 Enhances the Tumorigenicity of Immunogenic Rat Colon Carcinoma Cell Clones. Cancer Research. 1998;58(23)5495-5499.

Gatenby RA, Gillies RJ. Why do cancers have high aerobic glycolysis? Nat Rev Cancer. 2004;4(11)891-899.

Gervais A, Levêque J, Bouet-Toussaint F, Burtin F, Lesimple T, Sulpice L, Patard JJ, Genetet N, Catros-Quemener V. Dendritic cells are defective in breast cancer 
patients: a potential role for polyamine in this immunodeficiency. Breast Cancer Res. $2005 ; 7(3) 326-335$.

Gottfried E, Kunz-Schughart LA, Ebner S, Mueller-Klieser W, Hoves S, Andreesen R, Mackensen A, Kreutz M. Tumor-derived lactic acid modulates dendritic cell activation and antigen expression. Blood. 2006;107(5)2013-2021.

Guermonprez P, Valladeau J, Zitvogel L, Théry C, Amigorena S. Antigen presentation and $T$ cell stimulation by dendritic cells. Annu Rev Immunol. 2002;20:621-667.

Hercus TR, Thomas D, Guthridge MA, Ekert PG, King-Scott J, Parker MW, Lopez AF. The granulocyte-macrophage colony-stimulating factor receptor: linking its structure to cell signaling and its role in disease. Blood. 2009;114(7)1289-1298.

Inaba K, Inaba M, Romani N, Aya H, Deguchi M, Ikehara S, Muramatsu S, Steinman RM. Generation of large numbers of dendritic cells from mouse bone marrow cultures supplemented with granulocyte/macrophage colony-stimulating factor. J Exp Med. 1992;176(6)1693-1702.

Ito T, Amakawa R, Inaba M, Ikehara S, Inaba K, Fukuhara S. Differential regulation of human blood dendritic cell subsets by IFNs. J Immunol. 2001;1(5)2961-2969.

Jacobs JF, Hoogerbrugge PM, De Rakt MW, Aarntzen EH, Figdor CG, Adema GJ, De Vries IJ. Phenotypic and functional characterization of mature dendritic cells from pediatric cancer patients. Pediatr Blood Cancer. 2007;49(7)924-927.

Jonuleit H, Schmitt E, Schuler G, Knop J, Enk AH. Induction of interleukin 10producing, nonproliferating CD4(+) $\mathrm{T}$ cells with regulatory properties by repetitive stimulation with allogeneic immature human dendritic cells. J Exp Med. 2000;192(9)1213-1222.

Jordan VC. Tamoxifen $(\mathrm{ICl} 46,474)$ as a targeted therapy to treat and prevent breast cancer. British Journal of Pharmacology. 2006;147(Suppl 1)S269-76.

Kang SH, Kang KW, Kim KH, Kwon B, Kim SK, Lee HY, Kong SY, Lee ES, Jang SG, Yoo BC. Upregulated HSP27 in human breast cancer cells reducesHerceptin susceptibility by increasing Her2 protein stability. BMC Cancer. 2008;8:1-10.

Kato M, Neil TK, Fearnley DB, McLellan AD, Vuckovic S, Hart DN. Expression of multilectin receptors and comparative FITC-dextran uptake by human dendritic cells. Int Immunol. 2000;12(11)1511-1519. 
Kim U, Baumler A, Carruthers C, Bielat K. Immunological escape mechanism in spontaneously metastasizing mammary tumors. Proc Natl Acad Sci USA. 1975;72(3)1012-1016.

Klein G. Mechanisms of escape from immune surveillance. Natl Cancer Inst Monogr. 1976;44:135-136.

Kobie JJ, Wu RS, Kurt RA, Lou S, Adelman MK, Whitesell LJ, Ramanathapuram LV, Arteaga CL, Akporiaye ET. Transforming growth factor beta inhibits the antigenpresenting functions and antitumor activity of dendritic cell vaccines. Cancer Res. 2003;63(8)1860-1864.

Komi J, Lassila O. Nonsteroidal anti-estrogens inhibit the functional differentiation of human monocyte-derived dendritic cells. Blood. 2000;95(9)2875-2882.

Kostenko S, Moens U. Heat shock protein 27 phosphorylation: kinases, phosphatases, functions and pathology. Cell. Mol. Life Sci. 2009;66(20)3289-3307.

Kulig E. Estrogen receptor: structure and function in normal and neoplastic tissue. Postepy Biochem. 1994;40(4) 222-229.

Lang TJ. Estrogen as an immunomodulator. Clin Immunol. 2004;113(3)224-230.

Lattime EC, Stutman O. Tumor growth in vivo selects for resistance to tumor necrosis factor. J Immunol. 1989;143(12)4317-4323.

Laudanski K, De A, Miller-Graziano C. Exogenous heat shock protein 27 uniquely blocksdifferentiation of monocytes to dendritic cells. Eur. J. Immunol. 2007;37(10)2812-2824.

Liu T, Guevara OE, Warburton RR, Hill NS, Gaestel M, Kayyali US. Modulation of HSP27 alters hypoxia-induced endothelial permeability and related signaling pathways. J Cell Physiol. 2009;220(3)600-610.

Lyons $A B$. Analysing cell division in vivo and in vitro using flow cytometric measurement of CFSE dye dilution. J Immunol Methods. 2000;243(1-2)147-154.

Makarenkova VP, Shurin GV, Tourkova IL, Balkir L, Pirtskhalaishvili G, Perez L, Gerein V, Siegfried JM, Shurin MR. Lung cancer-derived bombesin-like peptides down-regulate the generation and function of human dendritic cells. J Neuroimmunol. 2003;145(1-2)55-67. 
Margolese RG, Hortobagyi GN, Buchholz TA. The Breast. In: Kufe DW, Pollock RE, Weichselbaum RR, Bast Jr RC, Gansler TS, Holland JF, Frei III E, editors. Cancer Medicine. 5th ed.Ontario: BC Decker; 2003. p.1879-1970.

Matsuura K, Yamaguchi Y, Ueno H, Osaki A, Arihiro K, Toge T. Maturation of dendritic cells and $\mathrm{T}$-cell responses in sentinel lymph nodes from patients with breast carcinoma. Cancer. 2006;106(6)1227-1236.

McKallip R, Li R, Ladisch S. Tumor gangliosides inhibit the tumor-specific immune response. J Immunol. 1999;163(7)3718-326.

Miller-Graziano CL, De A, Laudanski K, Herrmann T, Bandyopadhyay S. HSP27: an anti-inflammatory and immunomodulatory stress protein acting to dampen immune function. Novartis Found Symp. 2008;291:96-208.

Miller WL. Molecular biology of steroid hormone synthesis. Endocr Rev. 1988;9(3)295-318.

Mindnich R, Adamski J. Functional aspects of 17beta-hydroxysteroid dehydrogenase 1 determined by comparison to a closely related retinol dehydrogenase. J Steroid Biochem Mol Biol. 2007;104(3-5)334-339.

Mohamadzadeh M, Luftig R. Dendritic cells: In the forefront of immunopathogenesis and vaccine development - A review. J Immune Based Ther Vaccines. 2004;2(1)111.

Monti P, Leone BE, Zerbi A, Balzano G, Cainarca S, Sordi V, Pontillo M, Mercalli A, Di Carlo V, Allavena P, Piemonti L. Tumor-derived MUC1 mucins interact with differentiating monocytes and induce IL-10highlL-12low regulatory dendritic cell. J Immunol. 2004;172(12)7341-7349.

Moore KW, O'Garra A, De Waal Malefyt R, Vieira P, Mosmann TR. Interleukin-10. Annu Rev Immunol. 1993;11:165-90.

Morse MA, Chui S, Hobeika A, Lyerly HK, Clay T. Recent developments in therapeutic cancer vaccines. Nat Clin Pract Oncol. 2005;2(2)108-113..

Murashov AK, Haq IU, Hill C, Park E, Smith M, Wang X, Wang X, Goldberg DJ, Wolgemuth DJ. Crosstalk between p38, Hsp25 and Akt in spinal motor neurons after sciatic nerve injury. Mol Brain Res. 2001;93(2)199-208..

Nagaraj S, Ziske C, Schmidt-Wolf IG. Dendritic cell, the immunotherapeutic cell for cancer. Indian J Med Res. 2004;119(4)133-138. 
Nagata Y, Ono S, Matsuo M, Gnjatic S, Valmori D, Ritter G, Garrett W, Old LJ, Mellman I. Differential presentation of a soluble exogenous tumor antigen, NY-ESO1 , by distinct human dendritic cell populations. Proc Natl Acad Sci USA. 2002;99(16)10629-10634.

Nakahara T, Moroi Y, Uchi H, Furue M. Differential role of MAPK signaling in human dendritic cell maturation and Th1/Th2 engagement. J Dermatol Sci. 2006;42(1)1-11..

Naik SH. Demystifying The development of dendritic cell subtypes, a little. Immunol. Cell Biol. 2008;86(5)439-452.

Nalbandian G, Paharkova-Vatchkova V, Mao A, Nale S, Kovats S. The selective estrogen receptor modulators, tamoxifen and raloxifene, impair dendritic cell differentiation and activation. J Immunol. 2005;175(4)2666-2675.

Neidhardt-Berard EM, Berard F, Banchereau J, Palucka AK. Dendritic cells loaded with killed breast cancer cells induce differentiation of tumor-specific cytotoxic $T$ lymphocytes. Breast Cancer Res. 2004;6(4)322-328.

Nencioni A, Brossart P. Cellular immunotherapy with dendritic cells in cancer: current status. Stem Cells. 2004;22(4)501-513.

Neves AR, Ensina LF, Anselmo LB, Leite KR, Buzaid AC, Câmara-Lopes LH, Barbuto JA. Dendritic cells derived from metastatic cancer patients vaccinated with allogeneic dendritic cell-autologous tumor cell hybrids express more CD86 and induce higher levels of interferon-gamma in mixed lymphocyte reactions. Cancer Immunol Immunother. 2005;54(1)61-66.

Ninomiya T, Akbar SM, Masumoto T, Horiike N, Onji M. Dendritic cells with immature phenotype and defective function in the peripheral blood from patients with hepatocellular carcinoma. J Hepatol. 1999;31(2)323-331.

O'Neill DW, Adams S, Bhardwaj N. Manipulating dendritic cell biology for the active immunotherapy of cancer. Blood. 2004;104(8)2235-2246.

Paharkova-Vatchkova V, Maldonado R, Kovats $\mathrm{S}$. Estrogen preferentially promotes the differentiation of $\mathrm{CD} 11 \mathrm{c}+\mathrm{CD} 11 \mathrm{~b}$ (intermediate) dendritic cells from bone marrow precursors. J Immunol. 2004;172(3)1426-1436.

Park SM, Kim S, Choi JS, Hur DY, Lee WJ, Lee MS, Choe J, Lee TH. TGF-beta inhibits Fas-mediated apoptosis of a follicular dendritic cell line by down-regulating the expression of Fas and caspase-8: counteracting role of TGF-beta on TNF sensitization of Fas-mediated apoptosis. J Immunol. 2005;174(10)6169-6175. 
Péguet-Navarro J, Sportouch M, Popa I, Berthier O, Schmitt D, Portoukalian J. Gangliosides from human melanoma tumors impair dendritic cell differentiation from monocytes and induce their apoptosis. J Immunol. 2003;170(7)3488-3494.

Pinzon-Charry A, Ho CS, Maxwell T, McGuckin MA, Schmidt C, Furnival C, Pyke CM, López JA. Numerical and functional defects of blood dendritic cells in early- and late-stage breast cancer. Br J Cancer. 2007;97(9)1251-1259.

Pikarsky E, Porat RM, Stein I, Abramovitch R, Amit S, Kasem S, Gutkovich-Pyest E, Urieli-Shoval S, Galun E, Ben-Neriah Y. NF-kB functions as a tumour promoter in inflammation-associated cancer. Nature. 2004;23(7007)461-466.

Polanczyk MJ, Jones RE, Subramanian S, Afentoulis M, Rich C, Zakroczymski M, Cooke P, Vandenbark AA, Offner $\mathrm{H}$. T lymphocytes do not directly mediate the protective effect of estrogen on experimental autoimmune encephalomyelitis. Am J Pathol. 2004;165(6)2069-2077.

Powles TJ, Hickish T. Tamoxifen Therapy and Carcinogenic Risk. Journal of the National Cancer Institute. 1995;87(18)1343-1345.

Puig-Kröger A, Pello OM, Selgas R, Criado G, Bajo MA, Sánchez-Tomero JA, Alvarez V, del Peso G, Sánchez-Mateos P, Holmes C, Faict D, López-Cabrera M, Madrenas J, Corbí AL. Peritoneal dialysis solutions inhibit the differentiation and maturation of human monocyte-derived dendritic cells: effect of lactate and glucosedegradation products. J Leukoc Biol. 2003;73(4)482-492.

Pulendran B, Banchereau J, Burkeholder S, Kraus E, Guinet E, Chalouni C, Caron D, Maliszewski C, Davoust J, Fay J, Palucka K. Flt3-ligand and granulocyte colonystimulating factor mobilize distinct human dendritic cell subsets in vivo. J. Immunol. 2000;165(1)566-572.

Ratta M, Fagnoni F, Curti A, Vescovini R, Sansoni P, Oliviero B, Fogli M, Ferri E, Della Cuna GR, Tura S, Baccarani M, Lemoli RM. Dendritic cells are functionally defective in multiple myeloma: the role of interleukin-6. Blood. 2002;100(1)230-237.

Reichert TE, Scheuer C, Day R, Wagner W, Whiteside TL. The number of intratumoral dendritic cells and zeta-chain expression in $\mathrm{T}$ cells as prognostic and survival biomarkers in patients with oral carcinoma. Cancer. 2001;91(11)2136-2147.

Reiman JM, Kmieciak M, Manjili MH, Knutson KL. Tumor immunoediting and immunosculpting pathways to cancer progression. Semin Cancer Biol. 2007;17(4) 275-87. 
Rui Z, Jian-Guo J, Yuan-Peng T, Hai P, Bing-Gen R. Use of serological proteomic methods to find biomarkers associated with breast cancer. Proteomics. 2003;3(4)433-439.

Rutella S, Danese S, Leone G. Tolerogenic dendritic cells: cytokine modulation comes of age. Blood. 2006;1(9)1435-1440.

Sallusto $F$, Lanzavecchia A. Efficient presentation of soluble antigen by cultured human dendritic cells is maintained by granulocyte/macrophage colony-stimulating factor plus interleukin 4 and downregulated by tumor necrosis factor alpha. $J$ Exp Med. 1994;179(4)1109-1118.

Sallusto F, Palermo B, Lenig D, Miettinen M, Matikainen S, Julkunen I, Forster R, Burgstahler R, Lipp M, Lanzavecchia A. Distinct patterns and kinetics of chemokine production regulate dendritic cell function. Eur J Immunol. 1999;29(5)1617-1625.

Sasano H, Suzuki T, Takeyama J, Utsunomiya H, Ito K, Ariga N, Moriya T. 17-betahydroxysteroid dehydrogenase in human breast and endometrial carcinoma. A new development in intracrinology. Oncology. 2000;59(1) 5-12.

Saxon A, Feldhaus J, Robins RA. Single step separation of human $T$ and $B$ cells using AET treated srbc rosettes. J Immunol Methods. 1976;12(3-4)285-288.

Schmitt E, Gehrmann M, Brunet M, Multhoff GE, Garrido C. Intracellular and extracellular functions of heat shock proteins:repercussions in cancer therapy. Journal of Leukocyte Biology. 2007;81(1)15-27.

Schoppmann SF, Birner P, Stöckl J, Kalt R, Ullrich R, Caucig C, Kriehuber E, Nagy $\mathrm{K}$, Alitalo K, Kerjaschki D. Tumor-associated macrophages express lymphatic endothelial growth factors and are related to peritumoral lymphangiogenesis. Am J Pathol. 2002;161(3)947-956.

Schnurr M, Chen Q, Shin A, Chen W, Toy T, Jenderek C, Green S, Miloradovic L, Drane D, Davis ID, Villadangos J, Shortman K, Maraskovsky E, Cebon J. Tumor antigen processing and presentation depend critically on dendritic cell type and the mode of antigen delivery. Blood. 2005;105(6)2465-2472.

Schuler G, Schuler-Thurner B, Steinman RM. The use of dendritic cells in cancer immunotherapy. Curr Opin Immunol. 2003;15(2)138-147.

Sellin D. Tumour immunology. Prax Klin Pneumol. 1979;33(1)341-349.

Semenza GL. Regulation of hypoxia-induced angiogenesis: a chaperone escorts VEGF to the dance. J Clin Invest. 2001;108(1)39-40. 
Sharma S, Stolina M, Yang SC, Baratelli F, Lin J, Atianzar K, Luo J, Zhu L, Lin Y, Huang M, Dohadwala M, Batra RK, Dubinett SM. Tumor cyclooxygenase 2dependent suppression of dendritic cell function. Clin Cancer Res. 2003;9(3)961-968.

Sozzani S, Allavena P, D'Amico G, Luini W, Bianchi G, Kataura M, Imai T, Yoshie O, Bonecchi $\mathrm{R}$, Mantovani $\mathrm{A}$. Differential regulation of chemokine receptors during dendritic cell maturation: a model for their trafficking properties. J Immunol. 1998;161(3)1083-1086.

Steinman RM. Dendritic cells. Transplantation. 1981;31(3)151-155.

Steinman RM, Cohn ZA. Identification of a novel cell type in peripheral lymphoid organs of mice. I. Morphology, quantitation, tissue distribution. J Exp Med. $1973 ; 137(5) 1142-1162$.

Steinman RM, Turley S, Mellman I, Inaba K. The Induction of Tolerance by Dendritic Cells That HaveCaptured Apoptotic Cells. J. Exp. Med. 2000;191(2)411-416.

Steinman RM, Hawiger D, Nussenzweig MC. Tolerogenic Dendritic Cells. Annu. Rev. Immunol. 2003;21:685-711.

Stojadinovic A, Mittendorf EA, Holmes JP, Amin A, Hueman MT, Ponniah S, Peoples GE. Quantification and phenotypic characterization of circulating tumor cells for monitoring response to a preventive HER2/neu vaccine-based immunotherapy for breast cancer: a pilot study. Ann Surg Oncol. 2007;14(12)3359-3368.

Sun Q, Kong CT, Huang FP, Chan LC. Aberrant dendritic cell differentiation initiated by the MII-Een fusion gene does not require leukemic transformation. J Leukoc Biol. 2008;83(1)173-180.

Suzuki T, Moriya T, Ariga N, Kaneko C, Kanazawa M, Sasano H. 17Betahydroxysteroid dehydrogenase type 1 and type 2 in human breast carcinoma: a correlation to clinicopathological parameters. Br J Cancer. 2000;82(3)518-523.

Tada T, Ohzeki S, Utsumi K, Takiuchi H, Muramatsu M, Li XF, Shimizu J, Fujiwara H, Hamaoka, T. Transforming growth factor-beta-induced inhibition of $T$ cell function. Susceptibility difference in $\mathrm{T}$ cells of various phenotypes and functions and its relevance to immunosuppression in the tumor-bearing state. $J$ Immunol. $1991 ; 146(3) 1077-1082$.

Tamaoki B. Steroidogenesis and cell structure. Biochemical pursuit of sites of steroid biosynthesis. J Steroid Biochem. 1973;4(1)89-118. 
Torisu H, Ono M, Kiryu H, Furue M, Ohmoto Y, Nakayama J, Nishioka Y, Sone S, Kuwano, M. Macrophage infiltration correlates with tumor stage and angiogenesis in human malignant melanoma: possible involvement of TNF $\alpha$ and IL-1 $\alpha$. Int $\mathrm{J}$ Cancer. 2000;85(2)182-188.

Tourkova IL, Yamabe K, Foster B, Chatta G, Perez L, Shurin GV, Shurin MR. Murine prostate cancer inhibits both in vivo and in vitro generation of dendritic cells from bone marrow precursors. Prostate. 2004;59(2)203-213.

Trefzer U, Herberth G, Wohlan K, Milling A, Thiemann M, Sharav T, Sparbier K, Sterry W, Walden P. Tumour-dendritic hybrid cell vaccination for the treatment of patients with malignant melanoma: immunological effects and clinical results. Vaccine. 2005;23(17-18)2367-2373.

Tsung K, Dolan JP, Tsung YL, Norton JA. Macrophages as effector cells in interleukin 12-induced $\mathrm{T}$ cell-dependent tumor rejection. Cancer Res. 2002;62(17)5069-5075.

Uemura Y, Liu TY, Narita Y, Suzuki M, Matsushita S. 17 Beta-estradiol (E2) plus tumor necrosis factor-alpha induces a distorted maturation of human monocytederived dendritic cells and promotes their capacity to initiate T-helper 2 responses. Hum Immunol. 2008;69(3)149-157.

Vassiliou E, Jing H, Ganea D. Prostaglandin E2 inhibits TNF production in murine bone marrow-derived dendritic cells. Cell Immunol. 2003;223(2)120-132.

Villadangos JA, Schnorrer P. Intrinsic and cooperative antigen-presenting functions of dendritic-cell subsets in vivo. Nat Rev Immunol. 2007;7(7)543-555.

Vokaer R. Role of hormones in the genesis of breast cancer. J Gynecol Obstet Biol Reprod. 1975;4(2)189-197.

Warburg $O$. On the facultative anaerobiosis of cancer cells and its use in chemotherapy. Munch Med Wochenschr. 1961;103:2504-2506.

Waskiewicz AJ, Cooper JA. Mitogen and stress response pathways: MAP kinase cascades and phosphatase regulation in mammals and yeast. Current Opinion in Cell Biology. 1995;7(6)798-805.

White INH. The Tamoxifen dilemma. Carcinogeneses. 1999;20(7)1153-1160.

Yamamura M, Modlin RL, Ohmen JD, Moy RL. Local expression of antiinflammatory cytokines in cancer. J Clin Invest. 1993;91(3)1005-1010. 
Yanagihara S, Komura E, Nagafune J, Watarai H, Yamaguchi Y. EBI1/CCR7 is a new member of dendritic cell chemokine receptor that is up-regulated upon maturation. J Immunol. 1998;161(6)3096-3102.

Yue W, Wang JP, Li Y, Bocchinfuso WP, Korach KS, Devanesan PD, Rogan E, Cavalieri E, Santen RJ. Tamoxifen versus aromatase inhibitors for breast cancer prevention. Clin Cancer Res. 2005;11(2 Pt 2)925s-930s.

Zhou BP, Li Y, Hung MC. HER-2/Neu signaling and therapeutic approaches in breast cancer. Breast Dis. 2002;15:13-24.

Integrative Cancer Biology Program. (Cancer Cell Collection Home Page). Lawrence Berkeley National Laboratory. Berkeley. Disponível em: http://icbp.lbl.gov/breastcancer/celllines.php [visitado em 15 de julho de 2008]. 